\title{
ESPÉCIES DE MYRTACEAE DE UMA PARCELA PERMANENTE DE FLORESTA OMBRÓFILA DENSA BAIXO MONTANA NO PARQUE ESTADUAL CARLOS BOTELHO, MUNICÍPIO DE SETE BARRAS - SP.
}

\section{ALEXANDRE ROMARIZ DUARTE}

Dissertação apresentada à Escola Superior de Agricultura "Luiz de Queiroz", Universidade de São Paulo, para obtenção do título de Mestre em Ecologia de Agroecossistemas.

PIR A CIC AB A

Estado de São Paulo - Brasil

Agosto - 2003 


\title{
ESPÉCIES DE MYRTACEAE DE UMA PARCELA PERMANENTE DE FLORESTA OMBRÓFILA DENSA BAIXO MONTANA NO PARQUE ESTADUAL CARLOS BOTELHO, MUNICÍPIO DE SETE BARRAS - SP.
}

\section{ALEXANDRE ROMARIZ DUARTE}

Engenheiro Agrônomo

Orientador: Prof. Dr. VINICIUS CASTRO SOUZA

\begin{abstract}
Dissertação apresentada à Escola Superior de Agricultura "Luiz de Queiroz", Universidade de São Paulo, para obtenção do título de Mestre em Ecologia de Agroecossistemas.
\end{abstract}

PIR A CIC A B A

Estado de São Paulo - Brasil

Agosto - 2003 


\section{Dados Internacionais de Catalogação na Publicação (CIP) DIVISÃO DE BIBLIOTECA E DOCUMENTAÇ̃̃O - ESALQ/USP}

\section{Duarte, Alexandre Romariz}

Espécies de Myrtaceae de uma parcela pemanente de floresta ombrófila densa baixo montana no Parque Estadual Carlos Botelho, munic ípio de Sete Barras- SP / Alexandre Romaniz Duarte. - - Pirac ic aba, 2003.

77 p. : il.

Dissertação (mestrado) - - Escola Superior de Agricultura Luiz de Queiroz, 2003.

Bibliografia.

1. Área de conservação 2. Mata Atlântica 3. Mirtacea 4. Parque Esta dual Carlos Botelho 5. Vegetação nativa I. Título 
Dedico este trabalho àminha avó Claude Helene, aos meus pais Fernando e Manuella, e meus irmãos Cynthia e Eduardo. 


\section{AGRADECIMENTOS}

Gostaria de agradecer a todas as inúmeras pessoas que colaboraram para a realização deste trabalho, em especial:

Aos Profs. Dr. Vinicius Castro Souza, Dr. Ricardo Ribeiro Rodrigues e Dr. Alexandre Adalardo de Oliveira, pela amizade e por aceitarem compor meu comitê de orientação.

A CAPES, pela bolsa concedida no período de maio 2003 a agosto 2003.

A FAPESP, em especial ao Projeto Parcelas Permanentes, pelo apoio logístico na realização das etapas de campo.

A Diretoria e funcionários do Parque Estadual Carlos Botelho, pelo apoio, amizade e infra-estrutura oferecida.

Aos especialistas no estudo da família Marcos Sobral, Osny T. Aguiar, Evelyn Lucas, e Fiorella F. Mazine.

Ao programa de Pós Graduação Interunidades em Ecologia de Agroecossistemas - PPGIEA, pela oportunidade de realização do mestrado. Também a todos os colegas do programa pelo convívio e amizade nas horas difíceis.

À Regina, secretária de pós-graduação do PPGI-EA, pela compreensão e apoio dado aos alunos, facilitando à conclusão do trabalho.

A todos os colegas e funcionários do laboratório de Sistemática, e laboratório de Ecologia e Restauração Florestal do Departamento de Ciências Biológicas da ESALQ-USP.

À minha família por ter me dado apoio e incentivo, principalmente a minha irmã pela paciência e ajuda na fase final deste trabalho. 


\section{SUMÁRIO}

Página

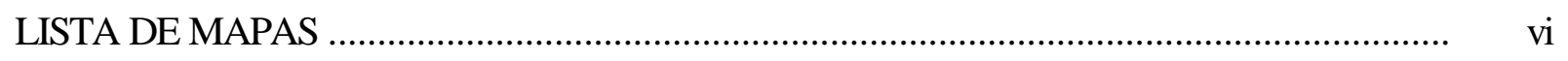

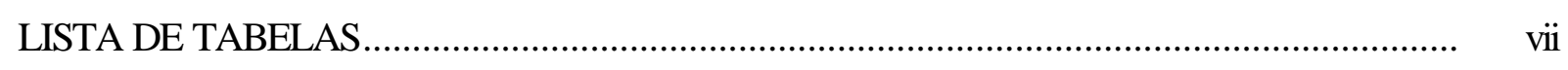

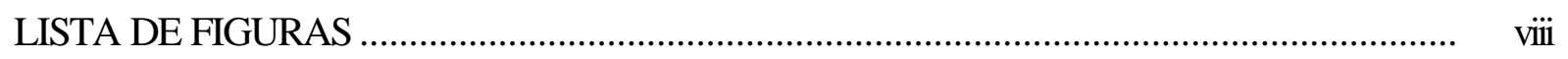

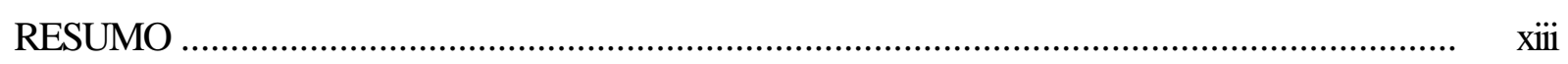

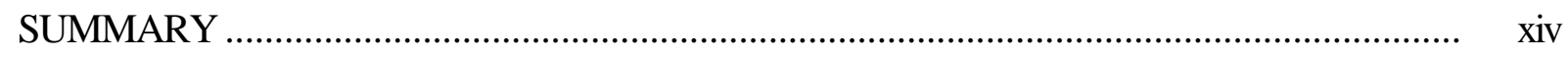

1 INTRODUÇÃ

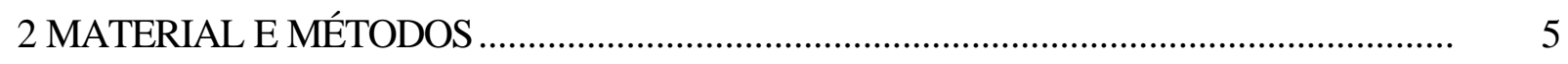

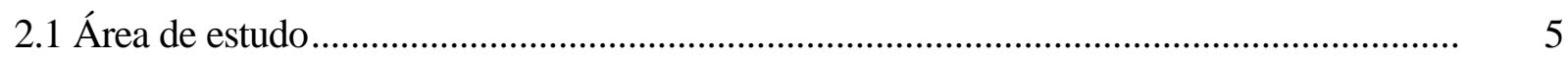

2.2 Instalação da Parcela Permanente ............................................................................ 7

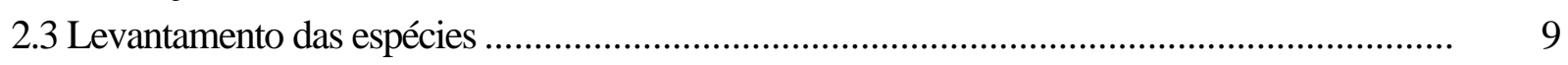

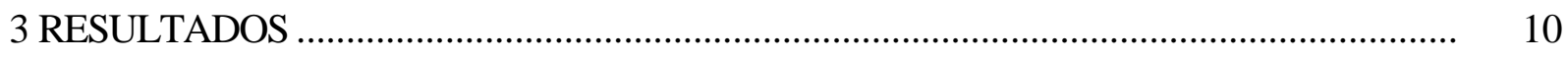

3.1 Listagem das espécies......................................................................................... 10

3.2 Chave para diferenciação das espécies de Myrtaceae da Parcela Permanente ..................... 13

3.3 Caracteres auxiliares para o reconhecimento das espécies............................................. 25

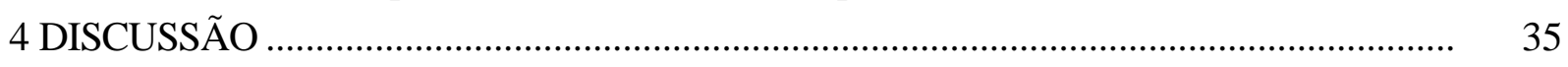

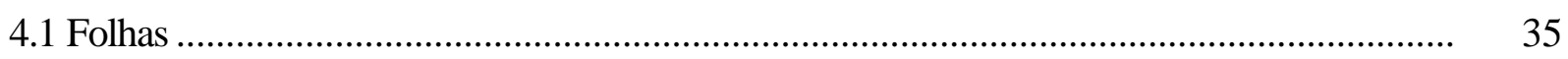

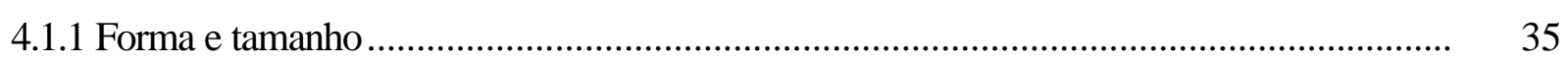

4.1.2 Pontuações translúcidas ................................................................................... 37

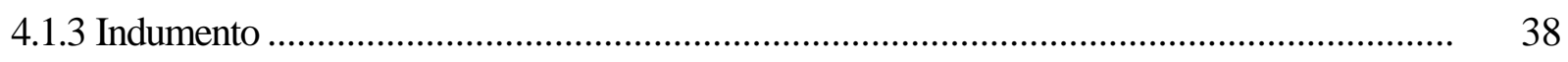

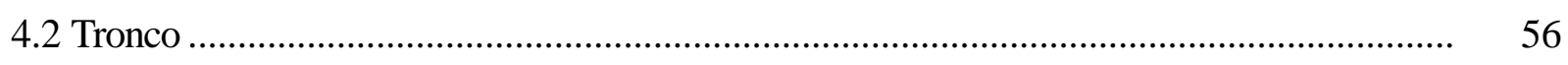

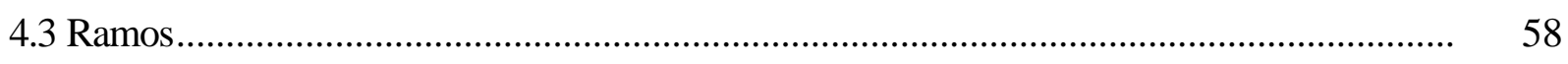

4.4. Aspectos ligados à densidade absoluta e freqüência absoluta........................................... 70

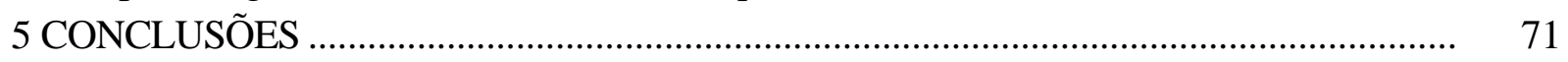

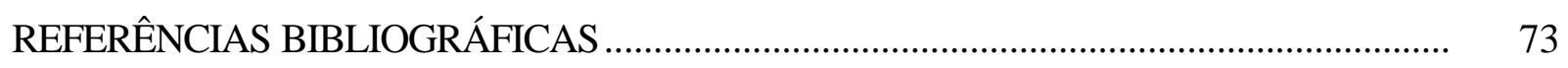




\section{LISTA DE MAPAS}

Página

1 Localização do Parque Estadual Carlos Botelho - SP. 05

2 Curvas de nível e distribuição dos indivíduos arbóreos da Parcela Permanente ....... 


\section{LISTA DE TABELAS}

Página

1 Lista de espécies de Myrtaceae encontradas em uma Parcela Permanente de 10,24 ha de floresta ombrófila densa baixo Montana no Parque Estadual Carlos Botelho; município de Sete Barras - SP; n.i = número de indivíduos; d.a. = densidade absoluta; Desvio padrão (densidade); f.a. = frequiência absoluta................. 


\section{LISTA DE FIGURAS}

Página

1 Ramos de espécies de Myrtaceae ocorrentes no Parque Estadual Carlos Botelho: A. Calycorectes australis; B. Calyptranthes lanceolata; C. Campomanesia guaviroba; D. Campomanesia sp. E. Eugenia bacopari; F. Eugenia beaurepaireana; G. Eugenia bocainensis; H. Eugenia bunchosiifolia; I. Eugenia cf. burkartiana.

2 Ramos de espécies de Myrtaceae ocorrentes no Parque Estadual Carlos Botelho: A. Eugenia cambucarana; B. Eugenia capitulifera; C. E. cerasiflora; D. E. cereja; E. E. copacabanensis; F. E. cuprea; G. E. handroana; H. E. melanogyna; I. E. mosenii.

3 Ramos de espécies de Myrtaceae ocorrentes no Parque Estadual Carlos Botelho: A. Eugenia multicostata; B. Eugenia neoglomerata; C. E. neoverrucosa; D. E. oblongata; E. E. platysema; F. E. pruinosa; G. E. riedeliana; H. E. schuechiana; I. Eugenia stictosepala

4 Ramos de espécies de Myrtaceae ocorrentes no Parque Estadual Carlos Botelho: A. Eugenia subavenia; B. E. xiriricana; C. Eugenia sp; D. Gomidesia anacardiaefolia; E. Gomidesia flagellaris; F. G. spectabilis; G. G. tijucensis; H. Marlierea eugeniopsoides; I. Marlierea obscura.....

5 Ramos de espécies de Myrtaceae ocorrentes no Parque Estadual Carlos Botelho: A. Marlierea suaveolens; B. Marlierea tomentosa; C. Myrceugenia kleinii; D. M. myrcioides; E. M. pilotantha; F. M. aff freyreissiana; G. Myrcia pubipetala; H. M. tenuivenosa; I. Myrciaria cf. floribunda.

6 Ramos de espécies de Myrtaceae ocorrentes no Parque Estadual Carlos Botelho: A. Neomitranthes glomerata; B. Plinia complanata, C. Plinia pauciflora

7 Folhas de espécies de Myrtaceae ocorrentes no Parque Estadual Carlos Botelho: A. Calycorectes australis - face inferior; B. C. australis - face superior; C. Calyptranthes lanceolata - face inferior; D. C. lanceolata face superior; E. Campomanesia guaviroba - face inferior; F. $C$. guaviroba - face superior 
8 Folhas de espécies de Myrtaceae ocorrentes no Parque Estadual Carlos Botelho: A. Campomanesia sp - face inferior; B. Campomanesia sp face superior; C. Eugenia bacopari - face inferior; D. E. bacopari - face superior; E. E. beaurepaireana - face inferior; F. E. beaurepaireana face superior

9 Folhas de espécies de Myrtaceae ocorrentes no Parque Estadual Carlos Botelho: A. Eugenia bocainensis - face inferior; B. E. bocainensis - face superior; C. E. bunchosiifolia - face inferior; D. E. bunchosiifolia - face superior; E. E. cf. burkartiana - face inferior; F. E. cf. burkartiana - face superior......

10 Folhas de espécies de Myrtaceae ocorrentes no Parque Estadual Carlos Botelho: A. Eugenia cambucarana - face inferior; B. Eugenia cambucarana - face superior; C. Eugenia capitulifera - face inferior; D. E. capitulifera - face superior; E. E. cerasiflora - face inferior; F. E. cerasiflora - face superior.

11 Folhas de espécies de Myrtaceae ocorrentes no Parque Estadual Carlos Botelho: A. Eugenia cereja - face inferior, B. Eugenia cereja face superior; C. E. copacabanensis - face inferior; D. E. copacabanensis - face superior; E. E. cuprea - face inferior; F. E. cuprea - face superior.

12 Folhas de espécies de Myrtaceae ocorrentes no Parque Estadual Carlos Botelho: A. Eugenia handroana - face inferior; B. E. handroana face superior; C. Eugenia melanogyna - face inferior; D. E. melanogyna face superior; E. E. mosenii - face inferior; F. E. mosenii - face superior.

13 Folhas de espécies de Myrtaceae ocorrentes no Parque Estadual Carlos Botelho: A. Eugenia multicostata - face inferior; B. Eugenia multicostata - face superior; C. Eugenia neoglomerata - face inferior; D. E. neoglomerata - face superior; E. E. neoverrucosa - face inferior; F. E. neoverrucosa - face superior

14 Folhas de espécies de Myrtaceae ocorrentes no Parque Estadual Carlos Botelho: A. Eugenia oblongata - face inferior; B. Eugenia oblongata - face superior; C. Eugenia platysema - face inferior; D. E. platysema - face superior; E. E. pruinosa - face inferior; F. E. pruinosa face superior

15 Folhas de espécies de Myrtaceae ocorrentes no Parque Estadual Carlos Botelho: A. Eugenia riedeliana - face inferior; B. Eugenia riedeliana - face superior; C. Eugenia schuechiana - face inferior; D. E. 
schuechiana - face superior; E. E. stictosepala - face inferior; F. E. stictosepala - face superior.

16 Folhas de espécies de Myrtaceae ocorrentes no Parque Estadual Carlos Botelho: A. Eugenia subavenia - face inferior, B. E. subavenia face superior; C. E. xiriricana - face inferior; D. E. xiriricana - face superior; E. Eugenia sp - face inferior; F. Eugenia sp - face superior

17 Folhas de espécies de Myrtaceae ocorrentes no Parque Estadual Carlos Botelho: A. Gomidesia anacardiaefolia - face inferior; B. Gomidesia anacardiaefolia - face superior; C. Gomidesia flagellaris face inferior; D. G. flagellaris - face superior; E. G. spectabilis - face inferior; F. G. spectabilis - face superior

18 Folhas de espécies de Myrtaceae ocorrentes no Parque Estadual Carlos Botelho: A. Gomidesia tijucensis - face inferior, B. Gomidesia tijucensis - face superior; C. Marlierea eugeniopsoides - face inferior; D. M. eugeniopsoides - face superior; E. Marlierea obscura - face inferior; F. M. obscura - face superior.

19 Folhas de espécies de Myrtaceae ocorrentes no Parque Estadual Carlos Botelho: A. Marlierea suaveolens - face inferior; B. $M$. suaveolens - face superior; C. Marlierea tomentosa - face inferior; D. M. tomentosa - face superior; E. Myrceugenia kleinii - face inferior; F. M. kleinii - face superior.

20 Folhas de espécies de Myrtaceae ocorrentes no Parque Estadual Carlos Botelho: A. Myrceugenia myrcioides - face inferior; B.Myrceugenia myrcioides - face superior; C. Myrceugenia pilotantha face inferior; D. M. pilotantha - face superior; E. Myrcia aff. freyreissiana - face inferior; F. M. aff. freyreissiana - face superior

21 Folhas de espécies de Myrtaceae ocorrentes no Parque Estadual Carlos Botelho: A. Myrcia pubipetala - face inferior; B. Myrcia pubipetala - face superior; C. Myrcia tenuivenosa - face inferior; D. $M$. tenuivenosa - face superior; E. Myrciaria cf. floribunda - face inferior; F. Myrciaria cf.floribunda - face superior.

22 Folhas de espécies de Myrtaceae ocorrentes no Parque Estadual Carlos Botelho: A. Neomitranthes glomerata - face inferior; B. Neomitranthes glomerata - face superior; C. Plinia complanata - face inferior; D. P. complanata - face superior; E. Plinia pauciflora - face inferior; F. P. pauciflora - face superior. 
23 Troncos de espécies de Myrtaceae ocorrentes no Parque Estadual Carlos Botelho: A. Eugenia multicostata - aspecto extemo; B. E. multicostata - aspecto interno; C. Marlierea suaveolens - aspecto externo; D. M. suaveolens - aspecto interno; E. Eugenia bacopari aspecto externo; F. E. bacopari - aspecto interno.

24 Troncos de espécies de Myrtaceae ocorrentes no Parque Estadual Carlos Botelho: A. Eugenia cf. burkartiana - aspecto externo; B. E. cf. burkartiana - aspecto interno; C. Marlierea obscura - aspecto externo; D. M. obscura - aspecto interno; E. Myrciaria cf. floribunda - aspecto externo; F. M. cf. floribunda - aspecto interno.

25 Troncos de espécies de Myrtaceae ocorrentes no Parque Estadual Carlos Botelho: A. Myrcia aff. freyreissiana - aspecto externo; B. M. aff. freyreissiana - aspecto interno; C. Plinia complanata - aspecto externo; D. P. complanata - aspecto interno; E. Plinia pauciflora aspecto externo; F. P. pauciflora - aspecto interno

26 Troncos de espécies de Myrtaceae ocorrentes no Parque Estadual Carlos Botelho: A. Eugenia riedeliana - aspecto externo; B. E. riedeliana - aspecto interno; C. E. schuechiana - aspecto externo; D. E. schuechiana - aspecto interno; E. Myrcia pubipetala - aspecto externo; F. Myrcia pubipetala - aspecto interno

27 Troncos de espécies de Myrtaceae ocorrentes no Parque Estadual Carlos Botelho: A. Calyptranthes lanceolata - aspecto externo; B. C. lanceolata - aspecto interno; C. Eugenia handroana - aspecto externo; D. E. handroana - aspecto interno; E. Eugenia neoverrucosa - aspecto externo; F. E. neoverrucosa - aspecto interno

28 Troncos de espécies de Myrtaceae ocorrentes no Parque Estadual Carlos Botelho: A. Eugenia xiriricana - (indivíduo jovem) aspecto externo; B. E. xiriricana - (indivíduo jovem) aspecto interno; C. E. xiriricana - (indivíduo adulto) aspecto externo; D. E. xiriricana (indivíduo adulto) aspecto interno; E. Campomanesia guaviroba aspecto externo; F. Campomanesia guaviroba - aspecto interno

29 Troncos de espécies de Myrtaceae ocorrentes no Parque Estadual Carlos Botelho: A. Campomanesia sp - aspecto externo; B. Campomanesia sp - aspecto interno; C. Eugenia cereja - aspecto externo; D. E. cereja - aspecto interno; E. Eugenia oblongata - aspecto externo; F. E. oblongata - aspecto interno.

30 Troncos de espécies de Myrtaceae ocorrentes no Parque Estadual Carlos Botelho: A. Eugenia bocainensis - aspecto externo; B. E. 
bocainensis - aspecto interno; C. Eugenia cambucarana - aspecto externo; D. E. cambucarana - aspecto interno; E. Eugenia cuprea aspecto externo; F. E. cuprea - aspecto interno

31 Troncos de espécies de Myrtaceae ocorrentes no Parque Estadual Carlos Botelho: A. Eugenia pruinosa - aspecto externo; B. E. pruinosa aspecto interno; C. Eugenia melanogyna - aspecto externo; D. E. melanogyna - aspecto interno; E. Eugenia mosenii - aspecto externo; F. E. mosenii - aspecto interno

32 Troncos de espécies de Myrtaceae ocorrentes no Parque Estadual Carlos Botelho: A. Gomidesia anacardiaefolia - aspecto externo; B. G. anacardiaefolia - aspecto interno; C. Gomidesia spectabilis - aspecto externo; D. G. spectabilis - aspecto interno; E. Gomidesia tijucensis aspecto externo; F. G. tijucensis - aspecto interno 


\title{
ESPÉCIES DE MYRTACEAE DE UMA PARCELA PERMANENTE DE FLORESTA OMBRÓFILA DENSA BAIXO MONTANA NO PARQUE ESTADUAL CARLOS BOTELHO, MUNICÍPIO DE SETE BARRAS - SP.
}

\author{
Autor: ALEXANDRE ROMARIZ DUARTE \\ Orientador: Prof. Dr. VINICIUS CASTRO SOUZA
}

\section{RESUMO}

Com o objetivo de identificar as espécies arbóreas da família Myrtaceae, que estão presentes em uma Parcela Permanente no Parque Estadual Carlos Botelho, município de Sete Barras, foram realizadas onze expedições de coleta ao longo de um ano. Neste estudo foi realizado o levantamento das espécies arbóreas da família Myrtaceae, acima de 4,8 cm de DAP, em $256 \mathrm{sub}$-parcelas de 20x20m, totalizando uma área amostral de 10,24 ha. As identificações foram feitas com base na literatura, e posteriormente confirmadas através de comparação nos herbários ESA, SP, UEC e consulta a especialistas. Na Parcela Permanente foram identificadas 48 espécies da família, o que corresponde a aproximadamente $25 \%$ do total de espécies amostradas na área pelo projeto. No total foram encontrados 2254 indivíduos de Myrtaceae, o que corresponde a aproximadamente $20 \%$ do total de indivíduos arbóreos amostrados. Eugenia foi o gênero mais abundante com 26 espécies, seguido por Gomidesia e Marlierea com 4 espécies, Myrceugenia e Myrcia com 3, Campomanesia e Plinia com 2 espécies e Calycorectes, Calyptranthes, Myrciaria e Neomitranthes com 1 espécie. Os resultados obtidos permitem concluir que as espécies de maior frequência na área são Marlierea suaveolens Cambess., Eugenia cuprea (O. Berg) Nied., Gomidesia flagellaris D. Legrand, Marlierea tomentosa Cambess., e Neomitranthes glomerata (D. Legrand) D. Legrand em ordem decrescente. Elaborou-se também uma chave dicotômica, que em conjunto com o registro fotográfico das espécies ilustram o trabalho e auxiliarão na identificação no campo e no herbário em projetos futuros. 


\title{
MYRTACEAE SPECIES IN PERMANENT PLOT IN ATLANTIC RAIN FOREST AT CARLOS BOTELHO STATE PARK, SETE BARRAS CITY - SP.
}

\author{
Author: ALEXANDRE ROMARIZ DUARTE \\ Adviser: Prof. Dr. VINICIUS CASTRO SOUZA
}

\section{SUMMARY}

The aim of this work was to identify tree species of Myrtaceae from Carlos Botelho State Park, Sete Barras city. In this area 256 permanent plots of 20x20m (total $10,24 \mathrm{ha}$ ) were installed, and every tree above $4,8 \mathrm{~cm}$ DBH was collected during eleven field trips that were made in one year. The identifications were based on bibliography and later, confirmed through comparison at the herbaria ESA, SP and UEC and consults to specialists. 48 species of Myrtaceae were found at the permanent plots, which means approximately $25 \%$ of the area's floristic composition. Total of 2136 specimes were collected, which means approximately $20 \%$ of the total number of trees on the area. Eugenia was the most abundant genera with 26 species, followed by Gomidesia and Marlierea with 4 species, Myrceugenia and Myrcia with 3 species, Campomanesia and Plinia with 2 species, and Calycorectes, Calyptranthes, Myrciaria and Neomitranthes with 1 species each. Marlierea suaveolens Cambess., Eugenia cuprea (O. Berg) Nied., Gomidesia flagellaris D. Legrand, Marlierea tomentosa Cambess., and Neomitranthes glomerata (D. Legrand) D. Legrand were the most frequent species in this order. A dichotomous key for the species is presented, which along with a photographic record, illustrate this work and will help the identification of specimes on the field and in herbaria in future projects. 


\section{INTRODUÇÃO}

A floresta ombrófila densa ou mata atlântica de encosta é a denominação de um complexo vegetacional que ocorre paralelamente à costa brasileira, originalmente desde o Rio Grande do Norte até o Rio Grande do Sul, numa faixa de 4.000km de extensão, cobrindo aproximadamente 1,2 milhões de $\mathrm{km}^{2}$ (SOS Mata Atlântica, 1998; Myers et al., 2000). Essa grande amplitude geográfica e climática resulta numa enorme diversidade de ecossistemas muito complexos (Mantovani, 1990; Leitão-Filho, 1994; Mantovani, 1998; Ivanauskas et al., 2000; Oliveira-Filho \& Fontes, 2000; Scudeller et al., 2001).

Campos (1912) destaca a riqueza e diversidade dessa vegetação, devido principalmente à sua extensão e ao relevo em que ocorre. Segundo Leitão-Filho (1994) o relevo bastante acidentado das Serras do Mar e de Paranapiacaba, também influiu para a manutenção e conservação dos remanescentes localizados nessas regiões.

Para Dasman et al. (1973) a floresta ombrófila densa é um dos ecossistemas mais complexos e diversificados do planeta resultante de adaptações às condições de pluviosidade e umidade pouco variáveis, sendo alterações mais profundas causadas por variações edafoclimáticas.

Diversos autores (Cruz, 1974; Domingues \& Silva, 1988; Domingues \& Sério, 1989; Mantovani, 1998) têm referido o relevo de escarpas, onde são comuns os processos de escorregamentos naturais, como um dos fatores condicionantes da 
dinâmica dessa formação, interpretando a floresta ombrófila densa como um mosaico de trechos vegetacionais em diferentes estágios de sucessão. Para Custódio-Filho (2002) a complexidade é resultado não somente de sua ocorrência em diferentes latitudes, mas também os gradientes altitudinais, associados às características fisiográficas locais e à influência de diversas floras.

Estudos recentes têm demonstrado que a heterogeneidade de habitats, resultante de distúrbios como a queda de árvores, variações na pluviosidade e na disponibilidade de nutrientes do solo, é um dos principais fatores para a manutenção da diversidade (Wright et al., 1997). Em estimativa recente, Myers et al. (2000) apresenta uma quantidade aproximada de 8.000 espécies vegetais endêmicas dessa formação florestal.

Com aproximadamente 3.500 espécies (Barroso et al., 1984; Legrand, 1978), agrupadas em 100 gêneros (Landrum \& Kawasaki, 1997), e distribuídas principalmente nas zonas tropicais e subtropicais, Myrtaceae é uma das famílias mais importantes dos neotrópicos. No Brasil estima-se que ocorram aproximadamente 1.000 espécies (Landrum \& Kawasaki, 1997), sendo que para o Estado de São Paulo, segundo dados do Projeto "Flora Fanerogâmica do Estado de São Paulo", existem aproximadamente 320 espécies da família.

Myrtaceae é a família com maior riqueza específica em muitas formações naturais (Barroso et al., 1984), entre elas, a floresta ombrófila densa. Diversos trabalhos, como por exemplo, o de Ivanauskas et al. (2001), desenvolvido no município de PariqueraAçu-SP, destacam a família Myrtaceae como a de maior riqueza específica neste tipo de ecossistema. Resultados semelhantes encontrados por Scudeller et al. (2001) para o 
estado de São Paulo, e Oliveira-Filho \& Fontes (2000) para o Brasil, confirmam essa constatação.

No entanto, conforme destacado por Barroso (1995), existe uma dificuldade taxonômica inerente à família, principalmente devido às coleções pouco representativas da variabilidade e distribuição geográfica das espécies que a compõe.

Particularmente no caso das Myrtaceae, Landrum \& Kawasaki (1997) destacam a importância de se coletar materiais com flores e frutos para uma identificação realmente precisa. Essa dificuldade foi compartilhada no levantamento florístico do Parque Estadual Carlos Botelho realizado por Custódio-Filho et al. (1992), quando registraramse 11 espécies de Myrtaceae, embora estes autores tenham assinalado que diversos espécimes desta família haviam sido coletados mais não identificados. Custódio-Filho (2002) apresenta uma listagem que amplia esse número para 48 espécies, sendo, no entanto, somente 30 identificadas até ao nível de espécie.

Neste contexto, o presente trabalho no qual os indivíduos estão numerados e mapeados, proporcionando que sejam revisitados e coletados com flores e frutos, auxiliará na expansão do conhecimento ecológico e taxonômico das espécies estudadas, bem como no auxílio de seu reconhecimento em trabalhos posteriores que disponham somente de material vegetativo.

Segundo Leitão-Filho (1982), a maior área de floresta pluvial atlântica remanescente, está localizada na região sul do Estado, na qual está incluída o Parque Estadual Carlos Botelho. Ranta et al. (1998) e Silva \& Tabarelli (2000) alertam para a proteção imediata desses remanescentes maiores enfatizando também a importância de conexões entre eles e da manutenção de processos biológicos que auxiliem inclusive em 
atividades de manejo. Essa preocupação é ainda mais relevante quando consideramos que dados recentes apontam para a existência de 5 a $8 \%$ da área de cobertura original da mata atlântica, com o agravante desses remanescentes estarem sujeitos a ameaças devido à proximidade dos centros urbanos, ou grandes plantações, principalmente de cana de açúcar e eucalipto (Gascon et al., 2000).

O presente trabalho foi realizado no Parque Estadual Carlos Botelho, em área de floresta ombrófila densa baixo montana, e está integrado ao projeto temático "Diversidade, Dinâmica e Conservação em Florestas do Estado de São Paulo: 40 ha de parcelas permanentes". 


\section{MATERIAL E MÉTODOS}

\section{1 Área de estudo - Parque Estadual Carlos Botelho}

O Parque Estadual Carlos Botelho (PECB) possui área total de 37.794ha e encontra-se na região sul do Estado de São Paulo (Mapa 1), nas coordenadas 24000' a 24015'S e 47045' a 48010'W. Engloba parte dos municípios de São Miguel Arcanjo, Capão Bonito e Sete Barras, com altitudes que variam de 30 a 1003 m (Domingues \& Silva, 1988; Negreiros et al., 1995).

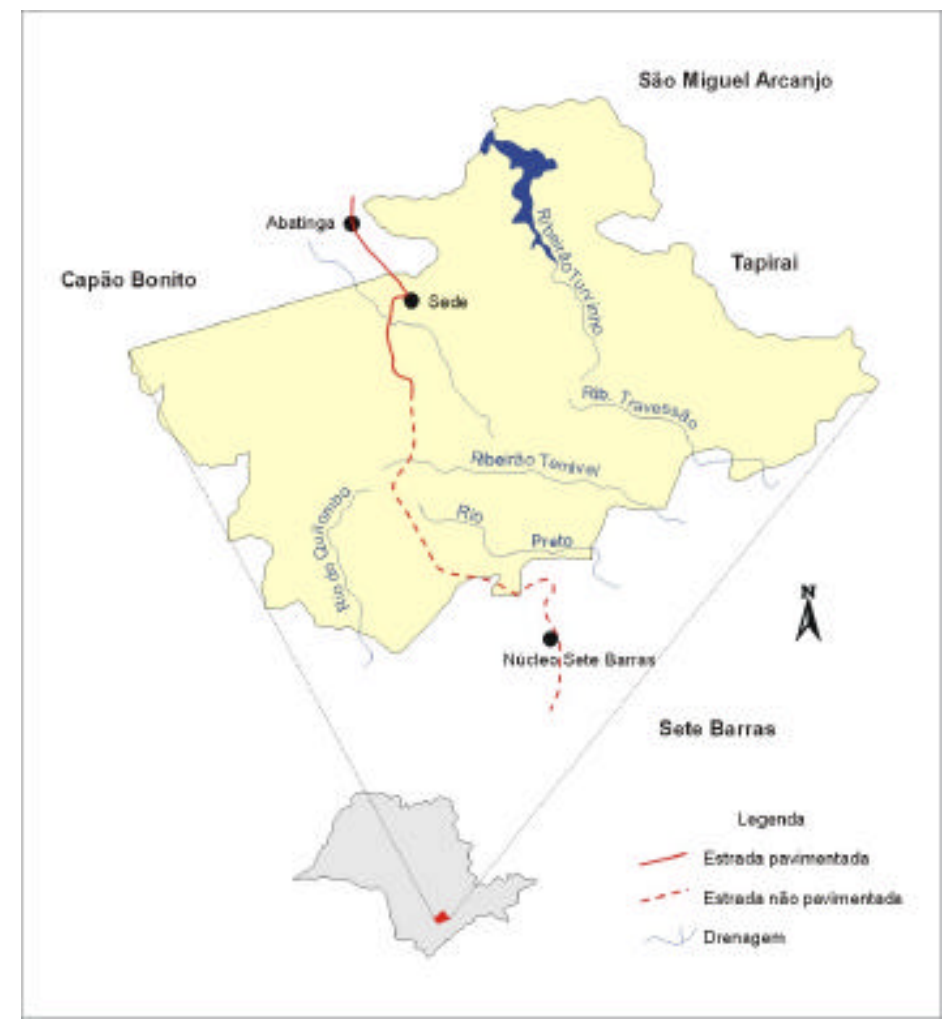

Mapa 1: Localização do Parque Estadual Carlos Botelho-SP 
A área do PECB compreende duas unidades geomorfológicas: o Planalto de Guapiara, drenado pelos rios que formam a bacia hidrográfica do rio Parapanema, e a Serra de Paranapiacaba, drenada pelos ribeirões Travessão, Temível e da Serra e pelos rios Preto e Quilombo, todos formadores da bacia do rio Ribeira de Iguape. Predominam no Parque as rochas graníticas, pertencentes a Facies Cantareira (IPT, 1981), que definem um relevo acidentado, que associado aos elevados índices pluviométricos, resultam em morfogênese acelerada nas médias e altas vertentes, e acúmulo de material nos sopés e canais fluviais (Domingues \& Silva, 1988).

Este relevo define, ainda, dois tipos climáticos diferentes, segundo a classificação de Köppen: a) clima quente úmido sem estiagem (Cfa): que ocupa áreas do Planalto de Guapiara com altitudes inferiores a $800 \mathrm{~m}$, a média e a baixa escarpa da Serra de Paranapiacaba, possuindo temperaturas inferiores a $18^{\circ} \mathrm{C}$ no mês mais frio e superiores a $22^{\circ} \mathrm{C}$ no mês mais quente, sendo o total pluviométrico do mês mais seco superior a 30 $\mathrm{mm}$;

b) clima temperado úmido sem estiagem (Cfb): nas partes mais elevadas da Serra de Paranapiacaba, diferindo do anterior apenas pela temperatura média do mês mais quente, que não ultrapassa $22^{\circ} \mathrm{C}$ (Setzer, 1946).

No Parque foram descritas a ocorrência de solos Hidromórficos e Podzólicos Vermelho-Amarelo "intergrade" Latossolo Vermelho-Amarelo (Camargo et al., 1987). Os solos do Parque caracterizam-se por possuir elevados teores de matéria orgânica e de alumínio, baixos teores de bases trocáveis e acidez elevada como a maioria dos solos da região serrana do litoral do Estado (Negreiros, 1982). 
No PECB ocorre a floresta atlântica de encosta (Veloso \& Góes Filho, 1982) onde foram realizados levantamentos por Custódio Filho et al. (1992) e Moraes (1992 e 1993) e fitossociológicos por Dias (1993), Negreiros (1982) e Negreiros et al. (1995). Para este estudo foi escolhido um trecho no núcleo Sete Barras, em altitude em torno de 300m, na vertente atlântica da Serra de Paranapiacaba, tendo o ponto A0 as coordenadas 202.827,9263 e 7.322.585,2885 em UTM no datum SAD69.

\subsection{Instalação da Parcela Permanente}

O presente estudo foi desenvolvido na Parcela Permanente alocada pelo projeto temático "Diversidade, Dinâmica e Conservação em Florestas do Estado de São Paulo: 40ha de parcelas permanentes". Neste projeto, que abrange outras três áreas, situadas no Parque Estadual da Ilha do Cardoso - Floresta de Restinga, Estação Ecológica dos Caetetus - Floresta Estacional Semidecidual, e Estação Ecológica de Assis - Cerradão, as parcelas de 10,24 ha foram divididas em 256 sub-parcelas de 20x20m, nas quais foram amostrados todos os indivíduos arbóreos com DAP (diâmetro à altura do peito) igual ou superior a 4,8cm (PAP - perímetro à altura do peito $\geq 15 \mathrm{~cm}$ ). Esta medida foi definida para possibilitar a comparação com os dados provenientes da maioria dos trabalhos realizados nas florestas do Estado de São Paulo, que utilizam o mesmo critério de inclusão dos indivíduos.

A alocação da parcela maior e sub-parcelas em cada área foi feita por equipe especializada de topografia, usando teodolito de alta precisão. Tanto a parcela como as sub-parcelas foram delimitadas com estacas permanentes. Em cada um dos quatro 
vértices da parcela permanente foram construídas marcações usando tubos de PVC de 1,5 m de altura (3/4" de diâmetro) preenchidos com cimento e com uma barra de ferro de 1/2". Para as marcações internas da parcela permanente foram utilizadas estacas de madeira tratada. Esta mesma equipe topográfica foi responsável pela marcação, numeração e mapeamento dos indivíduos (conforme Mapa 2).

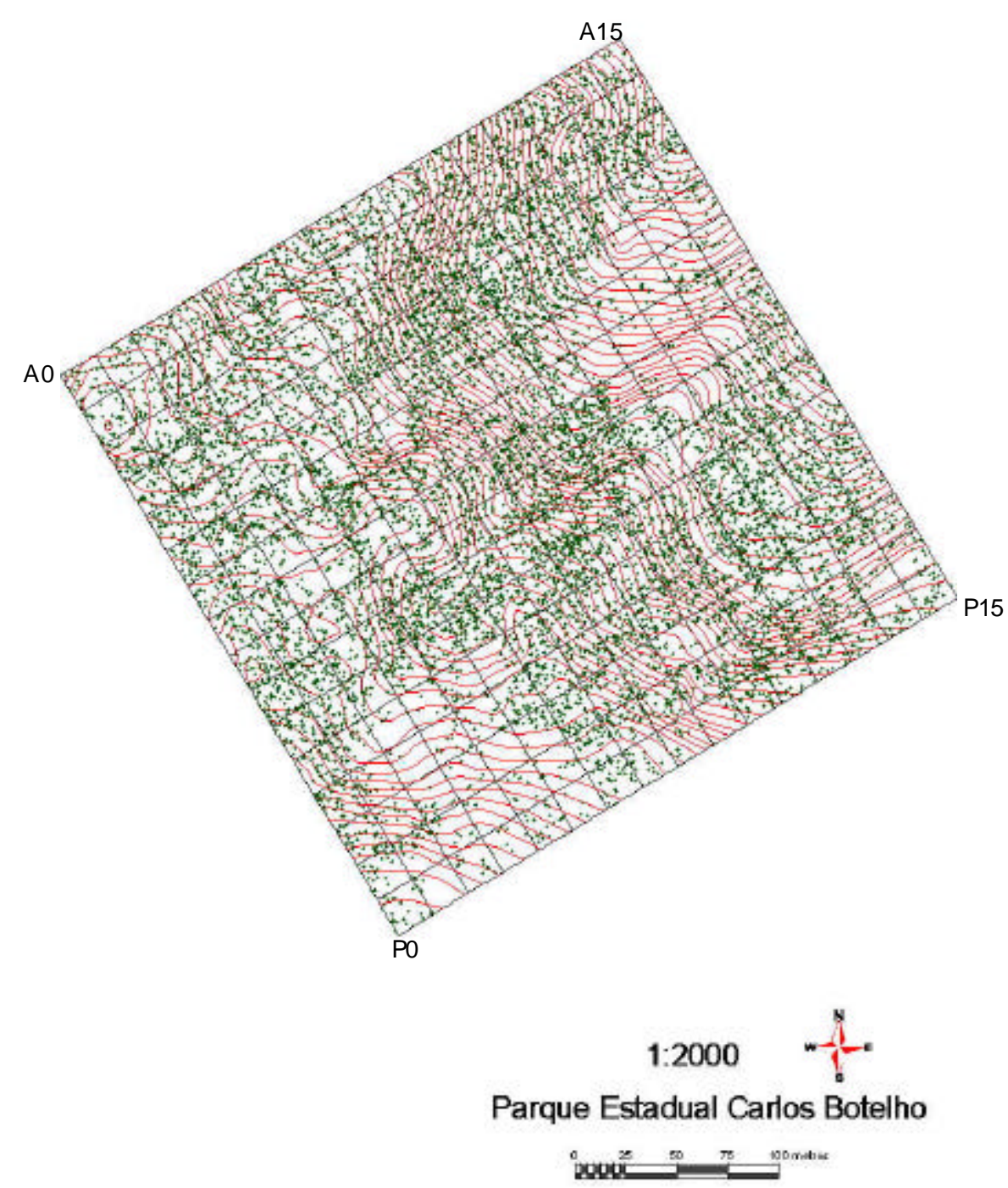

Mapa 2: Curvas de nível e distribuição dos indivíduos arbóreos da Parcela Permanente 


\subsection{Levantamento das espécies}

Foi realizado levantamento das $256 \mathrm{sub}$-parcelas de $400 \mathrm{~m}^{2}$ alocadas pelo projeto temático, sendo ramos férteis ou vegetativos dos indivíduos de Myrtaceae coletados para posterior identificação em laboratório.

A coleta dos materiais botânicos foi realizada seguindo os padrões usuais neste tipo de trabalho, conforme descrito por Fidalgo \& Bononi (1984). Para cada material coletado em estado fértil (com flores e/ou frutos) foram amostrados pelo menos cinco ramos e aqueles em estado vegetativo apenas dois ramos. Estes materiais foram prensados entre folhas de jornal e papelão e secos em estufa de campo, alocada na sede administrativa do Parque. Dados referentes à localização e numeração do indivíduo, porte, altura, coloração das flores e frutos, etc., foram anotados em campo para posterior elaboração de etiquetas que acompanharão o espécime.

A triagem e organização do material botânico coletado foram realizadas no Laboratório de Sistemática do Departamento de Ciências Biológicas, ESALQ/USP, onde os espécimes reprodutivos serão montados em cartolina e incorporados ao acervo do Herbário ESA. A identificação do material botânico coletado foi realizada utilizando bibliografia especializada, por comparação em outros herbários e consulta a especialistas.

A descrição morfológica dos caracteres vegetativos e reprodutivos aqui apresentada baseou-se no material coletado na área com complementações de literatura. O registro Fotográfico do tronco, folhas e estruturas reprodutivas, foi feito utilizando uma câmera Fotográfica digital Nikon Coolpix 995. 


\section{RESULTADOS}

\subsection{Listagem das espécies}

$\mathrm{Na}$ área correspondente as 256 sub parcelas (total de 10,24 ha) foram encontrados 2254 indivíduos de Myrtaceae com DAP igual ou superior a 4,8cm, destes 2136 (aproximadamente 95\%), foram identificados até nível de espécie. A lista, acompanhada pelo número total de indivíduos, densidade absoluta, desvio padrão da densidade absoluta e frequiência absoluta, estão apresentados na Tabela 1. Outros dados fitossociológicos serão tratados em trabalhos futuros, após a complementação do levantamento das parcelas e a identificação dos materiais das demais famílias.

Tabela 1. Lista de espécies de Myrtaceae encontradas em uma Parcela Permanente de 10,24 ha de floresta ombrófila densa baixo montana no Parque Estadual Carlos Botelho; município de Sete Barras SP; n.i.= número de indivíduos; d.a. = densidade absoluta; Desvio padrão (densidade); f.a.= freqüência absoluta

\begin{tabular}{|c|c|c|c|c|c|}
\hline Nome científico & n.i. & $\begin{array}{l}\text { d.a. } \\
\text { (ind/ha) }\end{array}$ & $\begin{array}{l}\text { Desvio } \\
\text { padrão }\end{array}$ & f.a. & $\begin{array}{c}\text { Voucher } \\
\text { Duarte, A.R. }\end{array}$ \\
\hline Eugenia cuprea(O. Berg) Nied. & 159 & 15.5 & 5.4 & $37.5 \%$ & 514 \\
\hline Marlierea suaveolens Cambess. & 143 & 14.0 & 4.3 & $40.6 \%$ & 536 \\
\hline Gomidesia flagellaris D. Legrand & 138 & 13.5 & 4.0 & $37.5 \%$ & 531 \\
\hline Marlierea tomentosa Cambess. & 125 & 12.2 & 3.0 & $32.8 \%$ & 537 \\
\hline Eugenia mosenii (Kausel) Sobral & 114 & 11.1 & 2.3 & $23.8 \%$ & 517 \\
\hline Eugenia melanogyna (D. Legrand) Sobral & 106 & 10.4 & 1.8 & $27.0 \%$ & 516 \\
\hline $\begin{array}{l}\text { Neomitranthes glomerata (D. Legrand) D. } \\
\text { Legrand }\end{array}$ & 97 & 9.5 & 1.1 & $28.5 \%$ & 545 \\
\hline
\end{tabular}


Tabela 1. Lista de espécies de Myrtaceae encontradas em uma Parcela Permanente de 10,24 ha de floresta ombrófila densa baixo montana no Parque Estadual Carlos Botelho; município de Sete Barras SP; n.i.= número de indivíduos; d.a. = densidade absoluta; Desvio padrão (densidade); fa.= freqüência absoluta

\begin{tabular}{|c|c|c|c|c|c|}
\hline Nome científico & n.i. & $\begin{array}{c}\text { d.a. } \\
\text { (ind/ha) }\end{array}$ & $\begin{array}{l}\text { Desvio } \\
\text { padrão }\end{array}$ & f.a. & $\begin{array}{c}\text { Voucher } \\
\text { Duarte, A.R. }\end{array}$ \\
\hline Calycorectes australis D. Legrand & 92 & 9.0 & 0.8 & $25.4 \%$ & 501 \\
\hline Eugenianeoglomerata Sobral & 89 & 8.7 & 0.6 & $23.4 \%$ & 519 \\
\hline Eugeniaxiriricana Mattos & 88 & 8.6 & 0.5 & $25.4 \%$ & 528 \\
\hline Marlierea obscura O. Berg & 81 & 7.9 & 0.0 & $23.4 \%$ & 535 \\
\hline Eugenia cambucarana Kiaersk. & 61 & 6.0 & 1.3 & $19.5 \%$ & 510 \\
\hline Eugenia oblongata O. Berg & 60 & 5.9 & 1.4 & $17.6 \%$ & 521 \\
\hline Gomidesia spectabilis (DC.) O. Berg & 53 & 5.2 & 1.9 & $16.4 \%$ & 532 \\
\hline Gomidesia anacardiaefolia (Gardner) O. Berg & 50 & 4.9 & 2.1 & $13.7 \%$ & 530 \\
\hline Eugenia subavenia $\mathrm{O}$. Berg & 49 & 4.8 & 2.2 & $13.7 \%$ & 527 \\
\hline Eugenia riedeliana O. Berg & 46 & 4.5 & 2.4 & $13.7 \%$ & 524 \\
\hline Gomidesia tijucensis (Kiaersk.) D. Legrand & 44 & 4.3 & 2.5 & $14.5 \%$ & 533 \\
\hline Eugenia platysema O. Berg & 43 & 4.2 & 2.6 & $14.1 \%$ & 522 \\
\hline Myrcia pubipetala Miq. & 41 & 4.0 & 2.8 & $14.5 \%$ & 541 \\
\hline Eugenia schuechiana O. Berg & 41 & 4.0 & 2.8 & $12.9 \%$ & 525 \\
\hline Calyptranthes lanceolata $\mathrm{O}$. Berg & 41 & 4.0 & 2.8 & $12.9 \%$ & 502 \\
\hline Myrciaria cf. floribunda (H. West ex Willd.) & 37 & 3.6 & 3.0 & $12.9 \%$ & 544 \\
\hline \multicolumn{6}{|l|}{ O. Berg } \\
\hline Eugenia stictosepala Kiaersk. & 34 & 3.3 & 3.3 & $9.8 \%$ & 526 \\
\hline Myrceugenia myrcioides (Cambess.) O. Berg & 32 & 3.1 & 3.4 & $10.9 \%$ & 539 \\
\hline \multicolumn{6}{|l|}{ Kausel) D. Legrand } \\
\hline Myrcia aff. freyreissiana (O. Berg) Kiaersk. & 26 & 2.5 & 3.8 & $9.0 \%$ & 542 \\
\hline Eugenia pruinosa D. Legrand & 24 & 2.3 & 4.0 & $8.6 \%$ & 523 \\
\hline Myrceugenia kleinii D. Legrand \& Kausel & 23 & 2.2 & 4.0 & $8.6 \%$ & 538 \\
\hline Eugenianeoverrucosa Sobral & 21 & 2.1 & 4.1 & $7.8 \%$ & 520 \\
\hline Plinia complanata M.L. Kawasaki \& B. Holst & 20 & 2.0 & 4.2 & $7.0 \%$ & 547 \\
\hline Eugenia cerasiflora Miq. & 19 & 1.9 & 4.2 & $7.4 \%$ & 512 \\
\hline Eugenia sp. & 18 & 1.8 & 4.3 & $6.6 \%$ & 529 \\
\hline
\end{tabular}


Tabela 1. Lis ta de espécies de Myrtaceae encontradas em uma Parcela Permanente de 10,24 ha de floresta ombrófila densa baixo montana no Parque Estadual Carlos Botelho; município de Sete Barras SP; n.i.= número de indivíduos; d.a. = densidade absoluta; Desvio padrão (densidade); f.a.= freqüência absoluta

\begin{tabular}{|c|c|c|c|c|c|}
\hline Nome científico & n.i. & $\begin{array}{c}\text { d.a. } \\
\text { (ind/ha) }\end{array}$ & $\begin{array}{l}\text { Desvio } \\
\text { padrão }\end{array}$ & f.a. & $\begin{array}{c}\text { Voucher } \\
\text { Duarte, A.R. }\end{array}$ \\
\hline Eugeniabunchosiifolia Nied & 15 & 1.5 & 4.5 & $5.9 \%$ & 508 \\
\hline Myrcia tenuivenosa Kiaersk. & 14 & 1.4 & 4.6 & $5.5 \%$ & 543 \\
\hline Eugenia capitulifera $\mathrm{O}$. Berg & 12 & 1.2 & 4.7 & $4.7 \%$ & 511 \\
\hline $\begin{array}{l}\text { Eugenia beaurepaireana (Kiaersk.) D. } \\
\text { Legrand }\end{array}$ & 8 & 0.8 & 5.0 & $3.1 \%$ & 506 \\
\hline Eugenia bocainensis Mattos & 7 & 0.7 & 5.1 & $2.7 \%$ & 507 \\
\hline Campomanesia guaviroba (DC.) Kiaersk. & 6 & 0.6 & 5.2 & $2.0 \%$ & 503 \\
\hline Eugenia multicostata D. Legrand & 5 & 0.5 & 5.2 & $1.2 \%$ & 518 \\
\hline Eugenia bacopari D. Legrand & 5 & 0.5 & 5.2 & $2.0 \%$ & 505 \\
\hline Plinia pauciflora M.L. Kawasaki \& B. Holst & 4 & 0.4 & 5.3 & $1.6 \%$ & 548 \\
\hline Eugenia cereja D. Legrand & 4 & 0.4 & 5.3 & $1.6 \%$ & 513 \\
\hline Campomanesia sp. & 4 & 0.4 & 5.3 & $1.6 \%$ & 504 \\
\hline Eugenia handroana D. Legrand & 3 & 0.3 & 5.4 & $1.2 \%$ & 515 \\
\hline $\begin{array}{l}\text { Eugenia cf. burkartiana (D. Legrand) D. } \\
\text { Legrand }\end{array}$ & 3 & 0.3 & 5.4 & $1.2 \%$ & 509 \\
\hline Myrceugenia pilotantha (Kiaersk.) Landrum & 1 & 0.1 & 5.5 & $0.4 \%$ & 540 \\
\hline Eugenia copacabanensis Kiaersk. & 1 & 0.1 & 5.5 & $0.4 \%$ & 546 \\
\hline
\end{tabular}




\subsection{Chave para diferenciação das espécies de Myrtaceae da Parcela Permanente}

1. Plantas com as folhas lanceoladas ou ovais ........................................................2

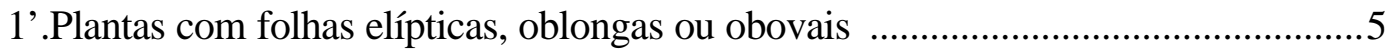

2. Folhas sempre com menos de $12 \mathrm{~cm}$.......................................... Plinia pauciflora

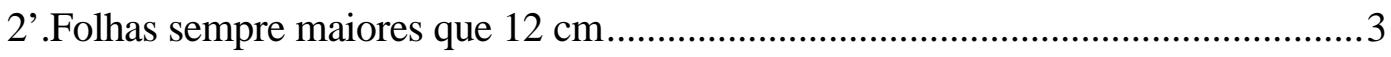

3. Pseudo-estípula presente ................................................Calyptranthes lanceolata

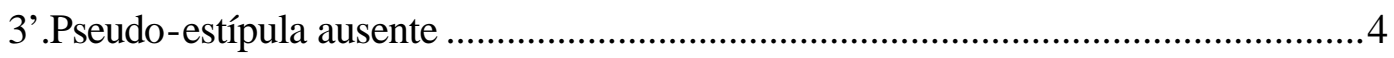

4. Folhas lanceoladas........................................................... Gomidesia spectabilis

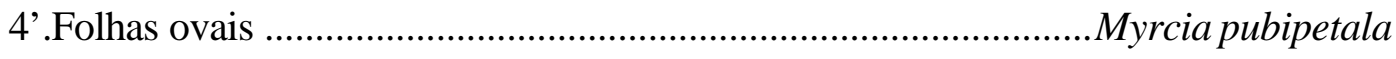

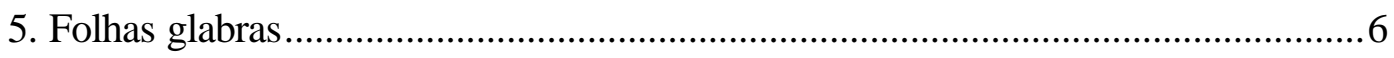

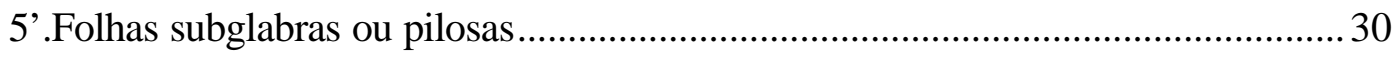

6. Folhas com nervura central proeminente na face superior .................................... 7

6'.Folhas com nervura central plana ou sulcada na face superior .............................. 11

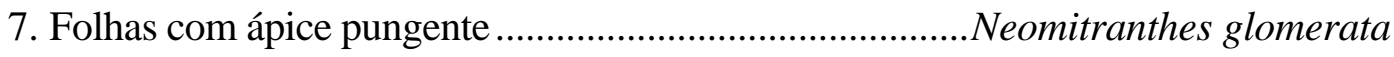

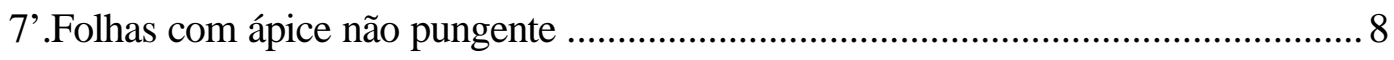

8. Folhas com pontuações translúcidas dificilmente visíveis; margem revoluta .........9

8'.Folhas com pontuações translúcidas facilmente visíveis, margem ondulada ......... 10

9. Pecíolo levemente sulcado, com pequenas pontuações amarelo-esbranquiçadas na face inferior das folhas .............................................................Eugenia stictosepala 9'.Pecíolo profundamente sulcado, sem pontuações amarelo-esbranquiçadas na face inferior das folhas Eugenia copacabanensis 
10. Folhas com coloração castanha quando secas e nervura central amareloavermelhada na face inferior Eugenia neoverrucosa 10’.Folhas inteiramente verdes após secagem Eugenia beaurepaireana

11. Plantas com a maioria das folhas obovais 12 11'.Plantas com folhas elípticas, oblongas, ou raramente com algumas folhas obovais 15

12. Folhas maiores que $12 \mathrm{~cm}$ de compr. .13

$12^{\prime}$.Folhas menores que $12 \mathrm{~cm}$ de compr...... 14

13. Nervuras inconspícuas no material fresco; pontuações esbranquiçadas na face inferior das folhas quando secas Eugenia melanogyna 13'.Nervuras conspícuas no material fresco; sem pontuações esbranquiçadas na face inferior das folhas quando secas. Eugenia mosenii 14. Folhas coriáceas com pontuações translúcidas pouco evidentes e tronco liso avermelhado .Eugenia multicostata 14'.Folhas membranáceas com pontuações translúcidas evidentes e tronco rugoso esbranquiçado Eugenia cereja 15. Folhas com ápice longamente acuminado; cerca de $1 \mathrm{~cm}$ compr. .16 15'.Folhas com ápice arredondado, curto-acuminado ou acuminado; em geral menores que $1 \mathrm{~cm}$ compr. 17

16. Maioria das folhas com menos de $2 \mathrm{~cm}$ de largura, com pontuações translúcidas muito evidentes e tronco verde externamente Marlierea suaveolens 16'.Maioria das folhas com mais de $2 \mathrm{~cm}$ de largura, com pontuações translúcidas pouco evidentes e tronco esbranquiçado externamente Eugenia capitulifera 
17. Folhas com nervura marginal coletora e nervuras secundárias impressas na face superior 18

17’.Folhas com nervura marginal coletora e nervuras secundárias inconspícuas ou fracamente proeminentes na face superior 20

18. Nervura marginal coletora inconspícua na face inferior

Campomanesia guaviroba

$18^{\prime}$.Nervura marginal coletora fortemente proeminente na face inferior. .19

19. Maior parte das folhas com mais de $10 \mathrm{~cm}$ compr.

Eugenia cf. burkartiana/Eugenia bacopari

19'.Maior parte das folhas menores que $10 \mathrm{~cm}$ compr. Eugenia platysema

20. Ramos jovens com coloração avermelhada

20'.Ramos acinzentados ou castanho-claros

21. Folhas com menos de $2,5 \mathrm{~cm}$ larg. Eugenia handroana

21'.Folhas com mais de $2,5 \mathrm{~cm}$ larg. .22

22. Folhas com margem plana e cartilaginosa Eugenia bunchosiifolia

22'.Folhas com margem ondulada e não cartilaginosa Eugenia cerasiflora

23. Plantas com pecíolo menor que $0,5 \mathrm{~cm}$ compr. .24

23'.Plantas com pecíolo maior que $0,5 \mathrm{~cm}$ compr. .26

24. Maioria das folhas com mais de $13 \mathrm{~cm}$ compr. Eugenia bocainensis

24'.Maioria das folhas com menos de $13 \mathrm{~cm}$ compr. .25

25. Ramos com ritidomas que se destacam. Myrcia aff. freyreissiana 25'.Ramos sem esta característica Eugenia cambucarana

26. Maioria das folhas com mais de $10 \mathrm{~cm}$ compr. 27 
26'.Maioria das folhas com menos de $10 \mathrm{~cm}$ compr.

27. Pecíolo enegrecido

Eugenia xiriricana

27’.Pecíolo acinzentado 28

28. Nervura principal da face inferior rígida, em forma de cunha; folhas concolores ...

Eugenia neoglomerata

28'.Nervura principal da face inferior não rígida, arredondada; folhas discolores

Eugenia pruinosa

29. Ramos grossos bastante achatados, folhas com ápice pungente

Myrceugenia kleinii

29’.Ramos delgados levemente achatados e folhas com ápice não pungente

Eugenia schuechiana/Eugenia sp.

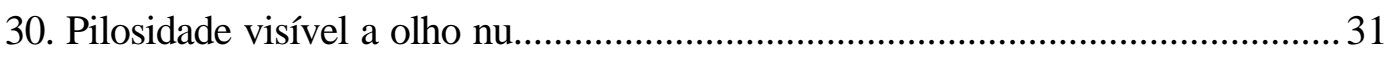

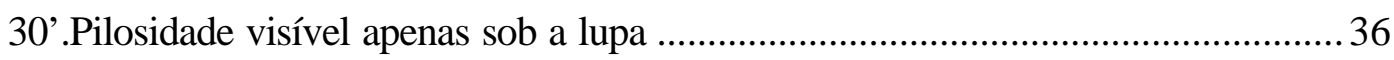

31. Tricomas ferrugíneos

Myrcia tenuivenosa

31'. Tricomas transparentes ou castanhos 32

32. Maioria das folhas com mais de $15 \mathrm{~cm}$ compr. Marlierea tomentosa

32'.Maioria das folhas com menos de $15 \mathrm{~cm}$ compr. .33

33. Tricomas castanhos abundantes concentrados sobre a nervura principal da face inferior das folhas jovens Marlierea obscura 33'.Tricomas transparentes ou avermelhados .34

34. Tricomas curtos, apressos ou subapressos concentrados sobre a gema apical e nervura principal da face inferior (gema com aspecto de pincel)

Gomidesia tijucensis 
34'.Tricomas longos e patentes distribuídos nos ramos e folhas jovens

35. Nervura marginal coletora proeminente na face inferior

Gomidesia anacardiaefolia

35'.Nervura marginal coletora inconspícua na face inferior Campomanesia sp.

36. Tricomas densamente distribuídos recobrindo toda a superfície inferior das folhas 37

36'.Tricomas esparsamente distribuídos recobrindo parcialmente a superfície inferior das folhas.

37. Tricomas transparentes ou brancos .Gomidesia flagellaris

37'. Tricomas de coloração ferrugínea ou castanha 38

38. Maioria dos tricomas são dibraquiados ..... Myrceugenia pilotantha

38'.Maioria dos tricomas são simples 39

39. Maioria das folhas com mais de $10 \mathrm{~cm}$ compr. Eugenia oblongata

39'.Maioria das folhas com menos de $10 \mathrm{~cm}$ compr. Eugenia cuprea

40. A maior parte dos tricomas dibraquiados Myrceugenia myrcioides

40'.Tricomas simples ou raramente dibraquiados..... 41

41. Folhas com ápice curtamente acuminado .42

41'.Folhas com ápice longamente acuminado ou rostrado .45

42. Ramos jovens esverdeados, fortemente achatados Plinia complanata 42'.Ramos acinzentados ou esbranquiçados, cilíndricos ou ligeiramente achatados 43 43. Folhas adultas com pecíolo rugoso esbranquiçado e pontuações translúcidas muito evidentes na face inferior Marlierea eugeniopsoides 
43'.Folhas adultas com pecíolo liso acinzentado e pontuações translúcidas pouco evidentes na face inferior 44

44. Maioria das folhas com menos de $10 \mathrm{~cm}$ compr. Eugenia subavenia 44'.Maioria das folhas com mais de $10 \mathrm{~cm}$ compr. Eugenia riedeliana 45. Nervura marginal coletora distante da margem; poucas nervuras secundárias bastante espaçadas entre si. Calycorectes australis 45'.Nervura marginal coletora próxima da margem; muitas nervuras secundárias bastante próximas entre si Myrciaria cf. floribunda 

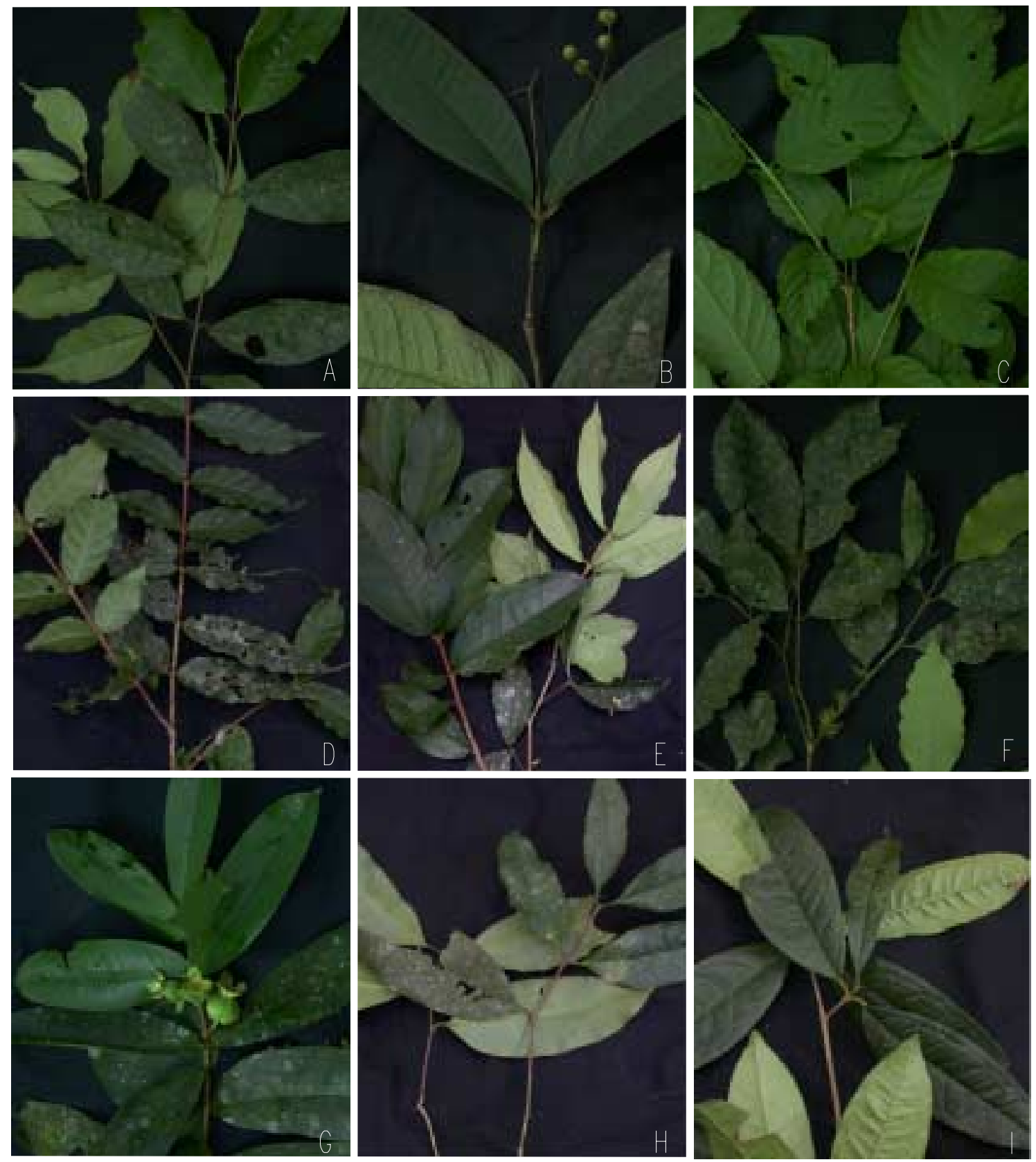

Figura 1 - Ramos de espécies de Myrtaceae ocorrentes no Parque Estadual Carlos Botelho: A. Calycorectes australis; B. Calyptranthes lanceolata; C. Campomanesia guaviroba; D. Campomanesia sp. E. Eugenia bacopari; F. Eugenia beaurepaireana; G. Eugenia bocainensis; H. Eugenia bunchosiifolia; I. Eugenia cf. burkartiana. 

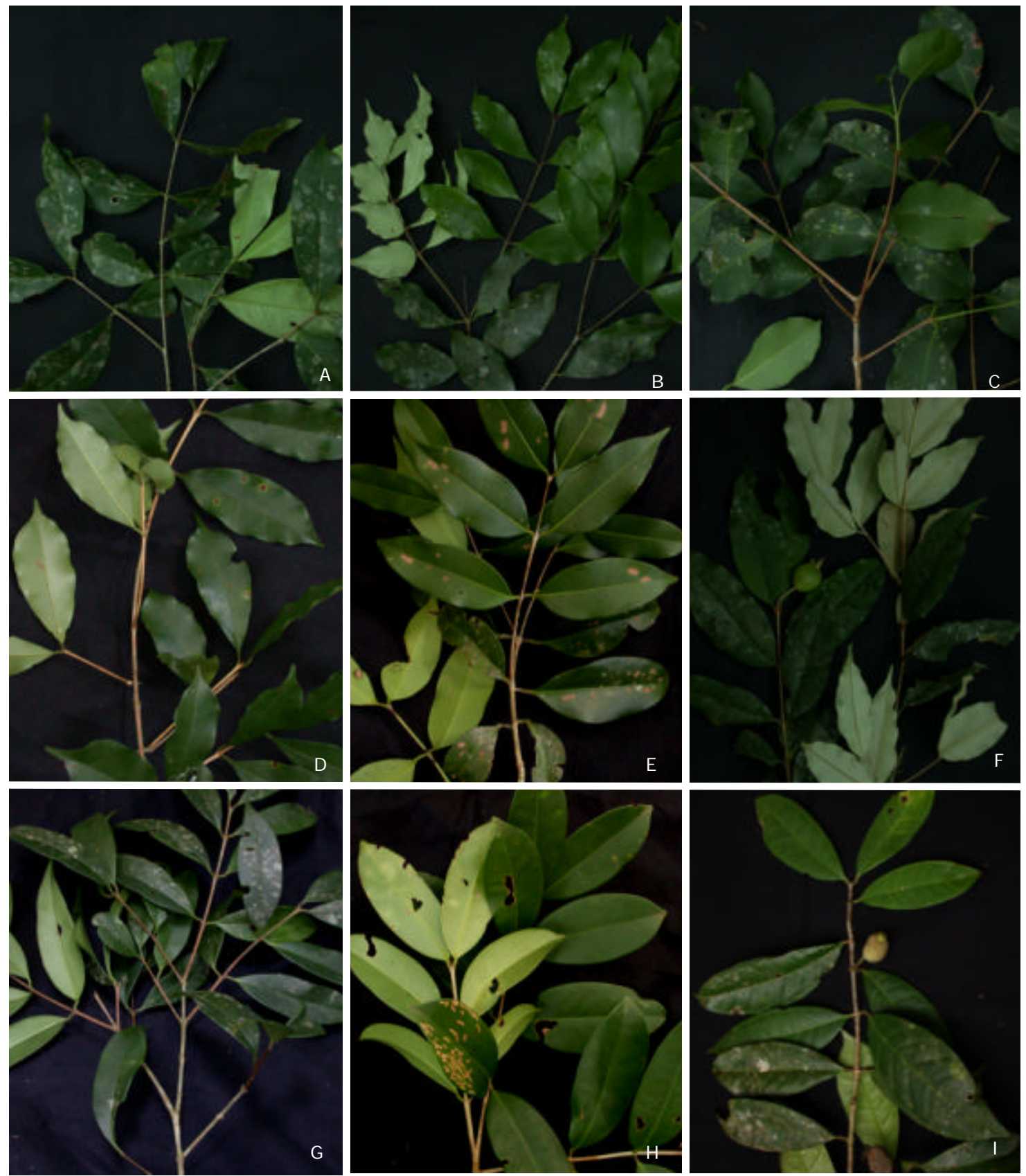

Figura 2 - Ramos de espécies de Myrtaceae ocorrentes no Parque Estadual Carlos Botelho: A. Eugenia cambucarana; B. Eugenia capitulifera; C. E. cerasiflora; D. E. cereja; E. E. copacabanensis; F. E. cuprea; G. E. handroana; H. E. melanogyna; I. E. mosenii. 

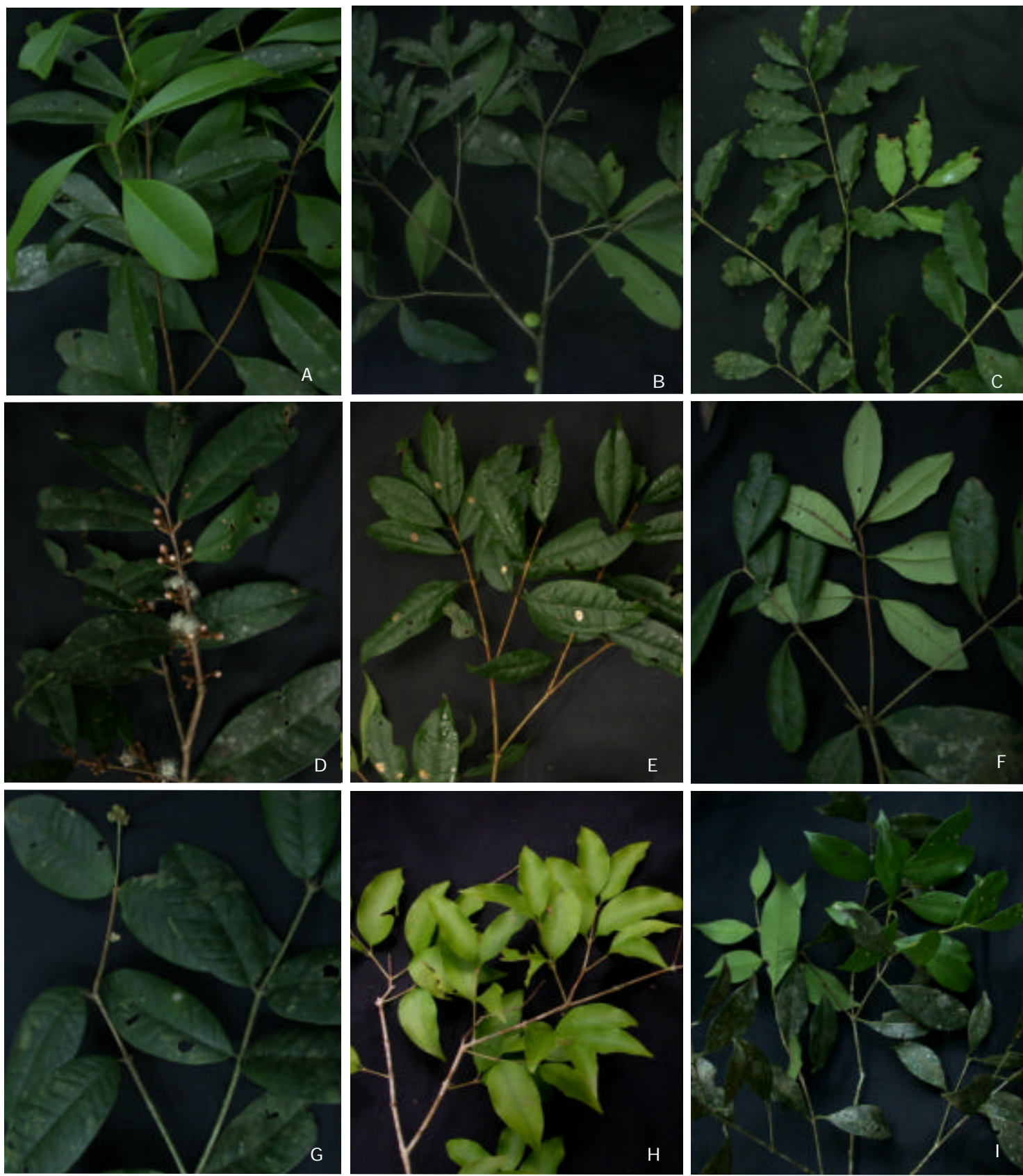

Figura 3 - Ramos de espécies de Myrtaceae ocorrentes no Parque Estadual Carlos Botelho: A. Eugenia multicostata; B. Eugenia neoglomerata; C. E. neoverrucosa; D. E. oblongata; E. E. platysema; F. E. pruinosa; G. E. riedeliana; H. E. schuechiana; I. Eugenia stictosepala. 

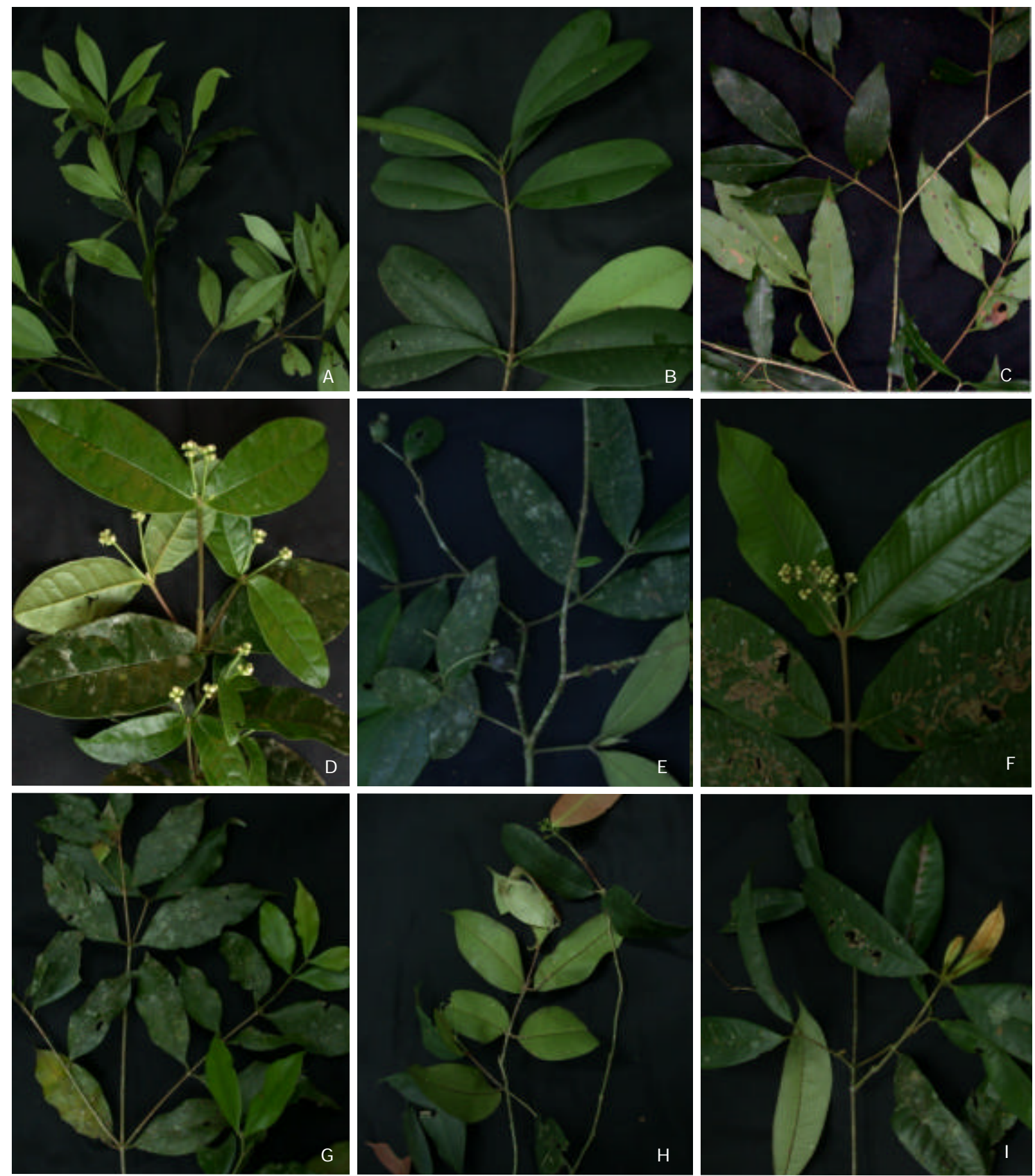

Figura 4 - Ramos de espécies de Myrtaceae ocorrentes no Parque Estadual Carlos Botelho: A. Eugenia subavenia; B. E. xiriricana; C. Eugenia sp.; D. Gomidesia anacardiaefolia; E. Gomidesia flagellaris; F. G. spectabilis; G. G. tijucensis; H. Marlierea eugeniopsoides; I. Marlierea obscura 

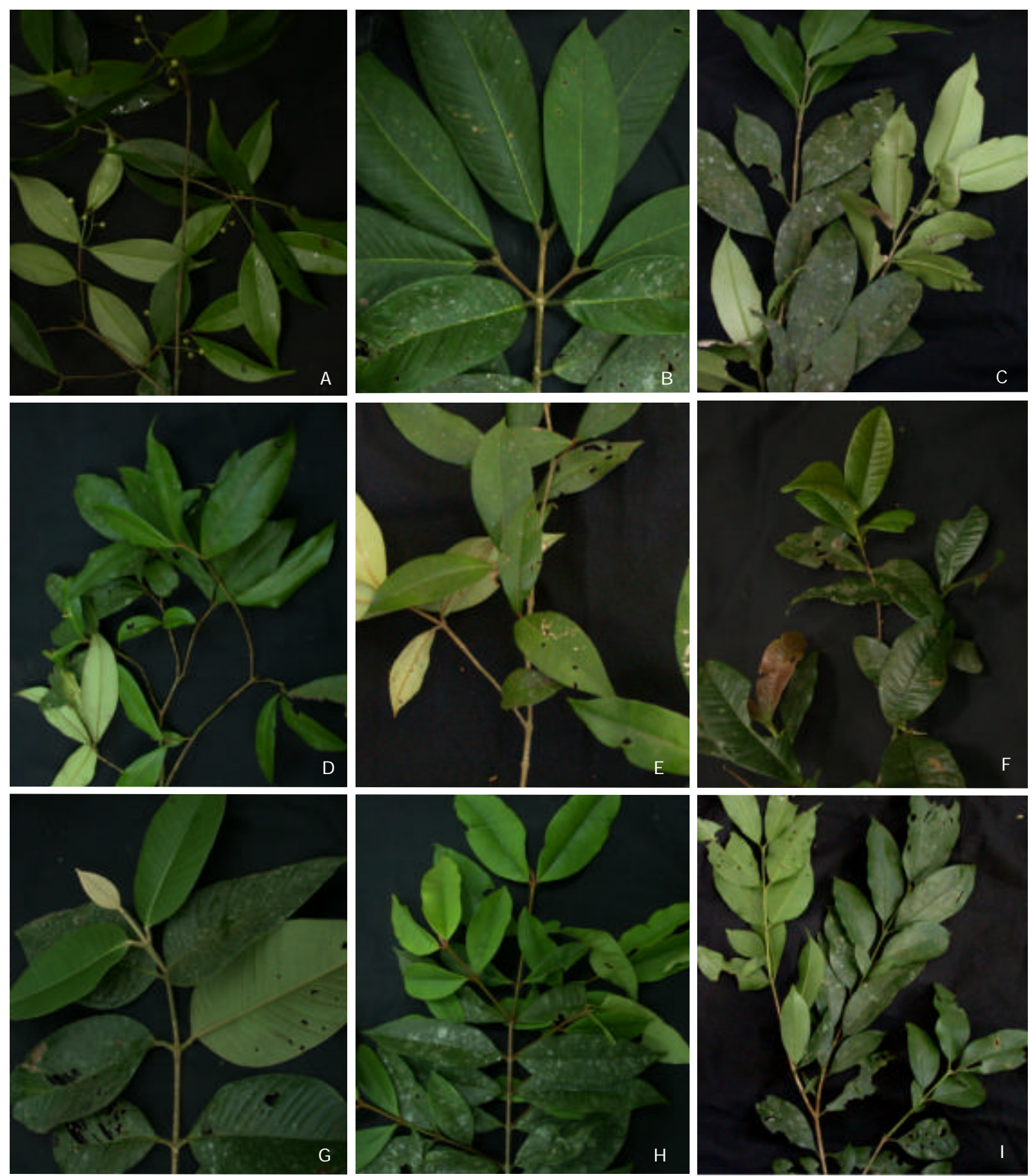

Figura 5 - Ramos de espécies de Myrtaceae ocorrentes no Parque Estadual Carlos Botelho: A. Marlierea suaveolens; B. Marlierea tomentosa; C. Myrceugenia kleinii; D. M. myrcioides; E. M. pilotantha; F. Myrcia aff. freyreissiana; G. Myrcia pubipetala; H. Myrcia tenuivenosa; I. Myrciaria cf. floribunda 

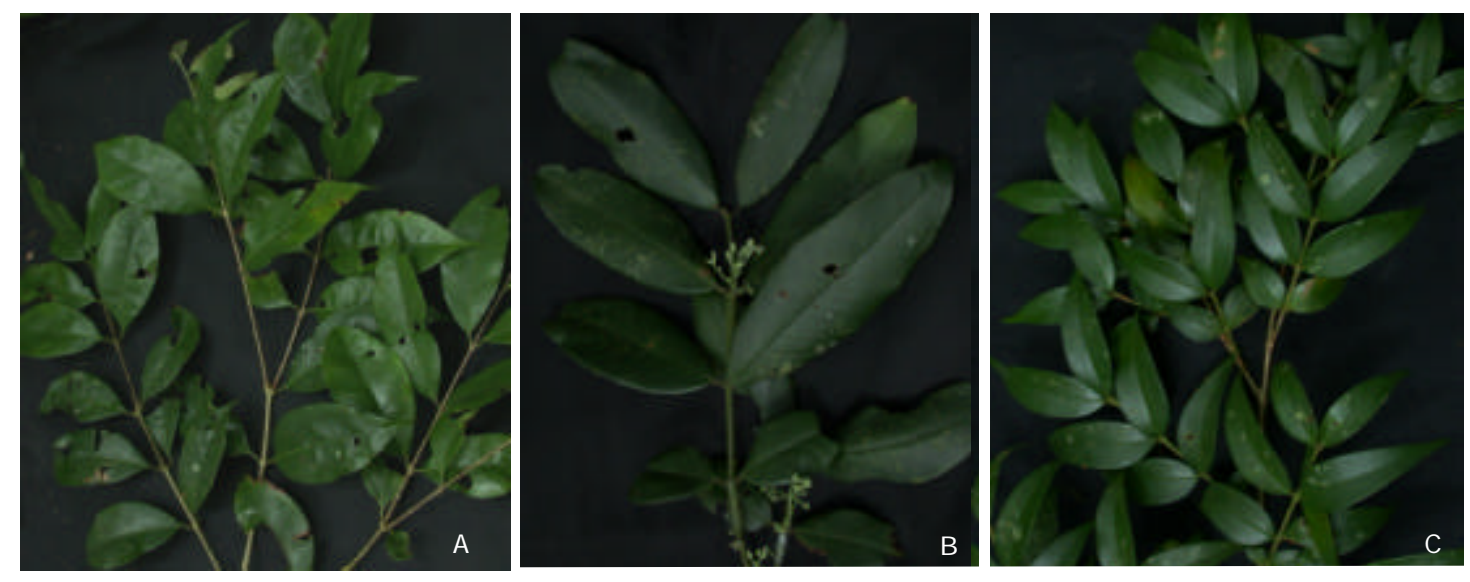

Figura 6 - Ramos de espécies de Myrtaceae ocorrentes no Parque Estadual Carlos Botelho: A. Neomitranthes glomerata; B. Plinia complanata; C. Plinia pauciflora 


\subsection{Caracteres auxiliares para o reconhecimento das espécies}

Este item tem por objetivo introduzir as espécies de Myrtaceae presentes na área de estudo, bem como destacar algumas características observadas tanto no campo quanto em herbário. Deve ser utilizado em conjunto com as fotos ilustrativas dos ramos, folhas e troncos, e com a chave analítica dicotômica, considerando a complexidade de identificação das espécies de Myrtaceae em estado vegetativo.

1.-) Calycorectes australis D. Legrand - (Figs.1A;7AB) Apresenta folhas com ápice rostrado e nervura coletora distanciada da margem. Pode ser confundida com Eugenia platysema, mas possui folhas maiores, mais membranáceas e com nervuras menos salientes na face inferior. Quando secas tendem a adquirir coloração castanha, ao passo que em E. platysema as folhas permanecem esverdeadas. Por fim, o ápice das folhas em E. platysema não é rostrado e as nervuras secundárias são impressas na face superior, ao passo que em $C$. australis são ligeiramente salientes no material seco.

2.-) Calyptranthes lanceolata O. Berg - (Figs.1B;7CD;27AB) São árvores de subosque que apresentam uma pseudoestípula muito característica que torna seu reconhecimento bastante fácil.

3.-) Campomanesia guaviroba (DC.) Kiaersk. - (Figs.1C;7EF;28EF) Esta espécie caracteriza-se por possuir o tronco fendido longitudinalmente, além de folhas cartáceas com nervura marginal pouco definida e margem subinteira.

4.-) Campomanesia sp. - (Figs.1D;8AB;29AB) Muito semelhante à espécie anterior, mas difere pelo tamanho menor das folhas e presença de indumento nos ramos jovens. 
5.-) Eugenia bacopari D. Legrand - (Figs.1E;8CD;23EF) Possui folhas com margem subrevoluta com nervuras impressas na face superior, proeminentes na inferior e nervura marginal coletora distante da margem. Pode ser confundida com E. platysema mas apresenta folhas muito maiores (comprimento superior a $15 \mathrm{~cm}$ ). Assemelha-se também a $E$. cf. burkartiana sendo que esta possui o pecíolo mais longo.

6.-) Eugenia beaurepaireana (Kiaersk.) D. Legrand - (Figs.1F;8EF) As folhas apresentam margem ondulada, evidente mesmo no material seco. Quando secas a face inferior das folhas apresenta coloração semelhante à face superior.

7.-) Eugenia bocainensis Mattos - (Figs.1G;9AB;30AB) Podem ser destacadas como características marcantes da espécie, a presença de folhas grandes (comprimento superior a 15cm), com pontuações translúcidas muito evidentes, formato oblongo a oblanceolado e pecíolo curto (comprimento inferior a $1 \mathrm{~cm}$ ). As folhas, além disso, concentram-se no ápice dos ramos, sendo que após a queda destas, as regiões dos nós tornam-se espessadas. Pode ser confundida com E. xiriricana, mas o pecíolo desta é mais longo (comprimento superior a 1cm), as folhas são mais coriáceas e as pontuações menos evidentes.

8.-) Eugenia bunchosiifolia Nied - (Figs.1H;9CD) Como característica marcante desta espécie podem ser destacadas as folhas com margem ondulada e cartilaginosa, face inferior relativamente brilhante e a coloração semelhante entre as duas faces quando secas.

9.-) Eugenia cf. burkartiana (D. Legrand) D. Legrand- (Figs.1I;9EF;24AB) espécie semelhante a E. bacopari podendo ser diferenciada por possuir folhas menores, 
ramos avermelhados mesmo em partes mais espessadas e pecíolo proporcionalmente maior em relação ao limbo.

10.-) Eugenia cambucarana Kiaersk. - (Figs.2A;10AB;30CD) Apresenta folhas elípticas com ápice acuminado, brilhantes na face inferior e com nervura central opaca e levemente rosada. Esta é uma das espécies de Myrtaceae mais comuns na área, sendo encontrada muitas vezes com as folhas lesionadas por um tipo de ferrugem.

11.-) Eugenia capitulifera O. Berg - (Figs.2B;10CD) Apresenta folhas pequenas (comprimento médio de 5cm), elípticas, com ápice longamente acuminado.

12.-) Eugenia cerasiflora Miq. - (Figs.2C;10EF) Apresenta ramos jovens avermelhados e pronunciadamente achatados. As folhas são elípticas com ápice curtamente acuminado, margem fortemente ondulada, e coloração opaca verde-oliva. As pontuações translúcidas são bastante evidentes a olho nu.

13.-) Eugenia cereja D. Legrand - (Figs.2D;11AB;29CD) Folhas obovais com ápice acuminado a rostrado e nervuras secundárias pouco evidentes na face inferior, mesmo no material seco. Possui pontuações evidentes a olho nu, assemelhando-se a $E$. multicostata, sendo que esta apresenta folhas mais coriáceas, pontuações menos evidentes, e tronco avermelhado.

14.-) Eugenia copacabanensis Kiaersk. - (Figs.2E;11CD) Semelhante a Neomitranthes glomerata, mas possui folhas mais coriáceas com pontuações não visíveis a olho nu. Assim como ocorre também para Myrceugenia pilotantha, esta espécie é representada na área somente por um único indivíduo.

15.-) Eugenia cuprea (O. Berg) Nied - (Figs.2F;11EF;30EF) espécie de fácil reconhecimento pela presença de um indumento castanho-claro a ligeiramente 
avermelhado recobrindo completamente a face inferior das folhas. Esta é uma das espécies de Myrtaceae mais comuns no subosque da área.

16.-) Eugenia handroana D. Legrand - (Figs.2G;12AB;27CD) Folhas elipticooblongas com ápice acuminado e consistência cartácea. A espécie assemelha-se a $E$. neoverrucosa, mas esta apresenta nervuras mais proeminentes na face inferior e nervura marginal coletora mais distanciada da margem. Além disso, no material seco, a nervura central da face superior é sulcada em E. handroana e proeminente em E. neoverrucosa.

17.-) Eugenia melanogyna (D. Legrand) Sobral - (Figs.2H;12CD;31CD) Folhas obovais com ápice curtamente acuminado, pontuações visíveis a olho nu, ramos esbranquiçados, fistulosos e fortemente achatados quando jovens. As nervuras secundárias não são facilmente visíveis no material fresco, mas são conspícuas quando secas. Quando vista na lupa, a folha apresenta, além das pontuações translúcidas, pontuações esbranquiçadas.

18.-) Eugenia mosenii (Kausel) Sobral - (Figs.2I;12EF;31EF) Folhas elípticas a oboval-elípticas com ápice acuminado, e nervura marginal coletora dupla, sendo a mais externa muito próxima da margem. Ramos achatados e fistulosos. No material fresco é muito evidente um "abaulamento" entre as nervuras secundárias da face inferior. Pode ser confundida com E. melanogyna, mas não apresenta as pontuações esbranquiçadas, e nesta, a nervura marginal coletora mais externa não é tão próxima àmargem.

19.-) Eugenia multicostata D. Legrand - (Figs.3A;13AB;23AB) Possui tronco vermelho-intenso pecíolo relativamente longo e limbo elíptico a oboval com ápice acuminado e margem subrevoluta. 
20.-) Eugenia neoglomerata Sobral - (Figs.3B;13CD) Possui folhas elípticas com ápice ligeiramente acuminado e nervura central rígida, muito proeminente na face inferior, semelhante a uma "quilha".

21.-) Eugenia neoverrucosa Sobral - (Figs.3C;13EF;27EF) espécie semelhante a E. cambucarana, mas apresenta folhas menores, com margem ondulada e coloração castanha quando secas.

22.-) Eugenia oblongata O. Berg - (Figs.3D;14AB;29EF) As folhas tornam-se castanhas quando secas e apresentam-se intensamente atacadas por fungos (característica observada em todos os materiais analisados) causando-lhes lesões circulares no limbo.

23.-) Eugenia platysema O. Berg - (Figs.3E;14CD) Semelhante a E. bacopari e a Calycorectes australis. Ver comentários nestas espécies.

24.-) Eugenia pruinosa D. Legrand - (Figs.3F;14EF;31AB) Folhas elípticas a oblongas, relativamente grandes (comprimento superior a $10 \mathrm{~cm}$ ), intensamente esbranquiçadas na face inferior, o que pode ser verificado mesmo mo material seco.

25.-) Eugenia riedeliana O. Berg - (Figs.3G;15AB;26AB) Folha elíptica com ápice acuminado. Uma característica marcante desta espécie é a presença de indumento tomentoso-ferrugíneo no ápice dos ramos jovens, que se desprende facilmente.

26.-) Eugenia schuechiana O. Berg - (Figs.3H;15CD;26CD) Comparativamente as outras espécies os pecíolos são mais longos. Possui folhas pequenas ovais a elípticas com ápice acuminado, assemelha-se a E. riedeliana, porém as folhas são bem menores, e não possui o indumento característico desta espécie.

27.-) Eugenia stictosepala Kiaersk. - (Figs.3I;15EF) Possui folhas estreitamente elípticas a oblanceoladas com ápice acuminado, nervura coletora distanciada da margem 
e nervação central saliente na face superior. Sob a lupa é possível verificar a existência de pontuações amarelo-esbranquiçadas pequenas e densamente dispostas, o que confere a face inferior das folhas um aspecto granulado a olho nu.

28.-) Eugenia subavenia O. Berg - (Figs.4A;16AB) Possui folhas pequenas, oblanceoladas, com ápice acuminado e ligeiramente discolores. Semelhante a $E$. stictosepala, mas a nervura central na face superior é sulcada, e não possui as pontuações características desta espécie.

29.-) Eugenia xiriricana Mattos - (Figs.4B;16CD;28ABCD) Folhas coriáceas, com margem revoluta e ápice arredondado, pecíolo espesso e escuro. Semelhante a $E$. multicostata, mas as folhas são maiores, e não possui o tronco avermelhado. Ambas as espécies apresentam ovário com costelas.

30.-) Eugenia sp. - (Figs.4C;16EF) Folhas membranáceas ovais a elípticas com ápice acuminado. Ramos jovens finos. Assemelha-se a E. cuprea, mas não possui o indumento característica desta espécie. Todos os indivíduos amostrados possuem folhas atacadas por ferrugem na região mediana. $\mathrm{O}$ material não foi coletado com flores ou frutos, e mesmo após diversas tentativas e consultas a outros especialistas, não foi possível uma identificação precisa. Há um certo consenso, de qualquer forma, quanto à sua semelhança com espécies do gênero Eugenia.

31.-) Gomidesia anacardiaefolia (Gardner) O. Berg - (Figs.4D;17AB;32AB) Possui folhas elípticas a obovais, base arredondada a subcordada, com pecíolo curto e nervuras intensamente sulcadas na face superior e salientes na inferior. Apresenta indumento formado por tricomas longos e patentes, muito evidentes nos ramos jovens e na nervura central na face inferior. 
32.-) Gomidesia flagellaris D. Legrand - (Figs.4E;17CD) Folhas elípticas, ligeiramente discolores, com margem revoluta. A gema terminal é relativamente grande, achatada e densamente pilosa. Quando em frutificação possui poucos frutos por inflorescência, a qual apresenta longo pedúnculo (ca. $5 \mathrm{~cm}$ ) e poucas flores.

33.-) Gomidesia spectabilis (DC.) O. Berg - (Figs.4F;17EF) Folhas grandes (comprimento superior a $20 \mathrm{~cm}$ ), lanceoladas, com ápice acuminado, pontuações bem visíveis, nervação bastante proeminente na face inferior e nervação marginal coletora distante da margem.

34.-) Gomidesia tijucensis (Kiaersk.) D. Legrand - (Figs.4G;18AB;32EF) Possui gemas terminais pequenas, densamente pilosas e aproximadamente do mesmo tamanho dos pecíolos. Folhas elípticas com ápice acuminado, cartáceas, e com pontuações translúcidas facilmente visíveis a olho nu.

35.-) Marlierea eugeniopsoides (D. Legrand \& Kausel) D. Legrand (Figs.4H;18CD) Árvore de pequeno a médio porte comum no subosque da floresta. Folhas elípticas a oblongo-elípticas, com ápice acuminado e pecíolo rugoso. Pontuações translúcidas "enquadradas" por divisões das nervações terciárias dando a impressão de estarem dentro de uma pequena célula.

36.-) Marlierea obscura O. Berg - (Figs.4I;18EF;24CD) Folhas elípticolanceoladas com ápice acuminado. Caracteriza-se por apresentar tronco descamante de coloração verde e branca e presença de muitos tricomas longos nas folhas jovens, principalmente sobre a nervura principal da face inferior.

37.-) Marlierea suaveolens Cambess. - (Figs.5A;19AB;23CD) Folhas geralmente elípticas a lanceoladas com ápice longamente acuminado. Caracteriza-se por 
possuir um tronco verde e muito liso, além de folhas fortemente aromáticas com pontuações translúcidas bastante evidentes.

38.-) Marlierea tomentosa Cambess. - (Figs.5B;19CD) Possui ramos espessos com ramificação pseudodicotômica. Folhas grandes, acima de $20 \mathrm{~cm}$ de comprimento, com pontuações translúcidas evidentes, pubescentes a sub glabras na face inferior.

39.-) Myrceugenia kleinii D. Legrand \& Kausel - (Figs.5C;19EF) Espécie semelhante a $M$. myrcioides. Ver comentários nesta espécie.

40.-) Myrceugenia myrcioides (Cambess.) O. Berg - (Figs.5D;20AB) Folhas elípticas com ápice acuminado ligeiramente pungente. Bastante semelhante a M. kleinii, diferindo desta por apresentar folhas com indumento de coloração castanha, e pecíolos menores, ao passo que em M. kleinii as folhas são totalmente glabras, os pecíolos são maiores, e as folhas um pouco mais coriáceas.

\section{1.-) Myrceugenia pilotantha (Kiaersk.) Landrum - (Figs.5E;20CD)} representada na área por um único indivíduo, assemelha-se a $M$. myrcioides, mas seu indumento é mais denso e ferrugíneo.

42.-) Myrcia pubipetala Miq. - (Figs.5G;21AB;26EF) Folhas ovais com ápice acuminado, base arredondada, coriáceas, com nervação pubescente, fortemente saliente na face inferior, pontuações translúcidas facilmente visíveis. O tamanho das folhas é bastante variável (aproximadamente de $10-35 \mathrm{~cm}$ de comprimento).

43.-) Myrcia aff. freyreissiana (O. Berg) Kiaersk. - (Figs.5F;20EF;25AB) Pode ser identificada por apresentar uma descamação escura nos ramos. As folhas são ovais à elípticas, com ápice acuminado, base arredondada e pecíolo curto. O tronco é avermelhado, porém em menor intensidade do que em E. multicostata. A identificação 
como "aff." justifica-se pelo fato de que estes materiais apresentam pecíolo menor e folhas menos coriáceas do que Myrcia freyreissiana.

44.-) Myrcia tenuivenosa Kiaersk. - (Figs.5H;21CD) Caracteriza-se por possuir tricomas ferrugíneos na porção terminal dos ramos e folhas lanceoladas a elípticolanceoladas, com nervuras numerosas e pouco salientes na face inferior, além de pontuações facilmente visíveis;

45.-) Myrciaria cf. floribunda - (Figs.5I;21EF;24EF) Semelhante a Myrcia tenuivenosa, mas é subglabra, possui pecíolo mais estreito e longo e pontuações pouco visíveis.

46.-) Neomitranthes glomerata (D. Legrand) D. Legrand - (Figs.6A;22AB) Caracteriza-se por possuir folhas elípticas com ápice acuminado, nervação central proeminente na face superior e pontuações translúcidas geralmente esparsas próximo à nervura central e evidentes próximo à margem.

47.-) Plinia complanata M.L. Kawasaki \& B. Holst - (Figs.6B;22CD;25CD) Folhas elípticas com ápice acuminado e textura cartácea. Caracteriza-se por apresentar um achatamento muito pronunciado dos ramos mais jovens. Apesar de ser comum, esta espécie foi recentemente descrita por Kawasaki \& Holst (2002), estando identificada na maioria dos herbários como Marlierea bipennis (O. Berg) McVaugh.

48.-) Plinia pauciflora M.L. Kawasaki \& B. Holst - (Figs.6C;22EF;25EF) Caracteriza-se por possuir tronco avermelhado, geralmente com descamações circulares, assemelhando-se em aspecto e coloração ao de Cryptocarya moschata Ness (Lauraceae). Possui ramos delgados, folhas pequenas (comprimento inferior a 10cm), lanceoladas, com ápice longamente acuminado. $\mathrm{O}$ formato das folhas assemelha-se ligeiramente ao 
de Myrcia rostrata DC., espécie comum em diversas formações florestais. Esta espécie também foi descrita recentemente no trabalho de Kawasaki \& Holst (2002). 


\section{DISCUSSÃO}

Entre os caracteres taxonômicos vegetativos utilizados para o reconhecimento das Myrtaceae estão características do tronco, folhas, gemas e pseudoestípulas conforme descrito a seguir.

\subsection{FOLHAS}

As folhas das Myrtaceae neotropicais são, via de regra, opostas, subcoriáceas, com pontuações translúcidas e nervura marginal coletora, o que se confirmou na área de estudo. Algumas características foliares possuem um significativo valor taxonômico, permitindo que a maioria das espécies pudesse ser reconhecida em campo, mesmo em estado vegetativo.

\subsubsection{Forma e tamanho}

Estas características estão entre as principais para o reconhecimento das espécies de Myrtaceae da área. Apesar de existir muita sobreposição, os extremos são facilmente reconhecíveis. Por exemplo: folhas excepcionalmente grandes podem ser encontradas em Calyptranthes lanceolata (Fig.7CD), Gomidesia spectabilis (Fig.17EF), Marlierea tomentosa (Fig.19CD) e Myrcia pubipetala (Fig.21AB). Apesar disto, esta última foi a espécie que apresentou maior variação intra-específica. No extremo oposto, com folhas bastante pequenas, pode-se citar: Campomanesia sp. (Fig.8AB), Eugenia capitulifera (Fig.10CD), Eugenia cuprea (Fig.11EF), Eugenia platysema (Fig.14CD), Eugenia schuechiana (Fig.15CD), Eugenia subavenia (Fig.16AB), Marlierea suaveolens 
(Fig.19AB) e Plinia pauciflora (Fig.22EF). Todas as demais espécies se apresentam na faixa intermediária entre os extremos expostos acima.

A maioria das folhas das Myrtaceae da área de estudo apresenta limbo com formato elíptico tendendo algumas vezes a oboval, oval ou oblongo. Poucas espécies fogem deste padrão, como é o caso de Calyptranthes lanceolata (Fig.7CD) e Gomidesia spectabilis (Fig.17EF), que apresentam folhas lanceoladas, de Eugenia cereja (Fig.11AB), Eugenia melanogyna (Fig.12CD) e Eugenia multicostata (Fig.13AB), com folhas obovais, de Eugenia bocainensis (Fig.9AB) e Eugenia oblongata (Fig.14AB), com folhas oblongas, ou ainda Myrcia pubipetala (Fig.21AB), que apresenta folhas ovais. Quase todas as espécies apresentam ápice acuminado, às vezes curtamente como em Eugenia cerasiflora (Fig.10EF) e Eugenia melanogyna (Fig.12CD), às vezes longamente acuminado, como em Eugenia capitulifera (Fig.10CD), Marlierea suaveolens (Fig.19AB) e Plinia pauciflora (Fig.22EF). Outros tipos de ápice incluem: ápice rostrado, presente em Calycorectes australis (Fig.7AB) e Eugenia cereja (Fig.11AB) e o arredondado presente em Eugenia xiriricana (Fig.16CD). A margem das folhas é geralmente inteira, exceto nas espécies de Campomanesia, onde é subinteira. Eugenia melanogyna (Fig.12CD), Eugenia multicostata (Fig.13AB), Gomidesia flagellaris (Fig.17CD) e Plinia complanata (Fig.22CD), apresentam margem revoluta, enquanto Eugenia beaurepaireana (Fig.8EF), Eugenia cambucarana (Fig.10AB) e Eugenia neoverrucosa (Fig.13EF) apresentam margem ondulada. 


\subsubsection{Pontuações translúcidas}

Embora todas as espécies na área possuam pontuações translúcidas, nem sempre estas são visíveis a olho nu. Existem as mais diversas variações, desde espécies com pontuações muito evidentes como em Marlierea suaveolens (Fig.19AB), Marlierea eugeniopsoides (Fig.18CD), Myrcia pubipetala (Fig.21AB) e Myrcia tenuivenosa (Fig.21CD), espécies com pontuações medianamente visíveis como em E. cerasiflora (Fig.10EF) e E. neoverrucosa (Fig.13EF), até espécies com pontuações não visíveis a olho nu, como Campomanesia guaviroba (Fig.7EF), Eugenia cuprea (Fig.11EF) e Gomidesia flagellaris (Fig.17CD). Analisando-se de maneira mais genérica, nota-se que as espécies de Marlierea e Myrcia presentes na área sempre apresentam pontuações visíveis, o mesmo pode ser dito das espécies de Gomidesia, à exceção de G. flagellaris (Fig.17CD). Já nas espécies de Campomanesia da área estudada, não foi possível visualizar pontuações a olho nu. Nos demais gêneros não parece haver um padrão quanto a esta característica. Algumas particularidades em relação às pontuações translúcidas podem ser destacadas, como no caso de Neomitranthes glomerata (Fig.22AB), que geralmente apresenta pontuações mais densas próximas à margem e mais esparsas próximo à nervura central. Em Marlierea suaveolens (Fig.19AB) há grande variação no tamanho das pontuações, havendo pontuações grandes e pequenas numa mesma folha, ou ainda em maior densidade próximo à base do pecíolo, porém, algumas vezes, elas também se apresentam uniformemente distribuídas pelo limbo. De maneira geral, a observação das pontuações se revelou uma característica auxiliar no reconhecimento de gêneros e até mesmo de algumas espécies, no entanto, há de se considerar que este caráter não foi útil isoladamente no reconhecimento dos táxons. 


\subsubsection{Indumento}

Apesar da maior parte das espécies de Myrtaceae encontradas na área ser glabra ou subglabra, o indumento de folhas e ramos é outra característica taxonômica bastante interessante, sendo sua importância ainda maior quando está disponível apenas material vegetativo. Em certas espécies a observação do indumento serve como auxílio no seu pronto reconhecimento, como, por exemplo, os tricomas longos e patentes encontrados em ramos e folhas de Gomidesia anacardiaefolia (Fig.17AB), a intensa pilosidade ferrugínea apresentada na porção terminal dos ramos e base da nervura central de Myrcia tenuivenosa (Fig.21CD), a gema curta e densamente pilosa assemelhando-se a um pequeno pincel em Gomidesia tijucensis (Fig.18AB), ou mesmo a coloração acobreada apresentada na face inferior das folhas de Eugenia cuprea (Fig.11EF), quando observadas sob a lupa. No entanto, geralmente observa-se que existe uma variação na intensidade do indumento com a idade da folha. Muitas vezes, nota-se uma pilosidade bastante intensa nas folhas novas de algumas espécies como, por exemplo, Marlierea obscura (Fig.18EF), Marlierea tomentosa (Fig.19CD) e Myrcia pubipetala (Fig.21AB), mas esta pilosidade fica menos evidenciada à medida que as folhas se tornam maduras, permanecendo muitas vezes apenas sobre a nervura principal da face inferior. Outras vezes a pilosidade é muito escassa, sendo visível somente com a utilização de lupas ou lentes de aumento, como ocorre em Myrciaria cf. floribunda (Fig.21EF) e Plinia complanata (Fig.22CD), entre outras.

Por fim, é interessante destacar que embora a pilosidade seja um dos itens de importância fundamental na chave apresentada no presente trabalho, vale a ressalva de que as variações observadas correspondem a um espectro muito pequeno se comparado 
com a distribuição geográfica das espécies como um todo, o que pode refletir principalmente características regionais, restringindo então a aplicação da chave do presente trabalho apenas para populações próximas da área estudada e de seu entorno. 

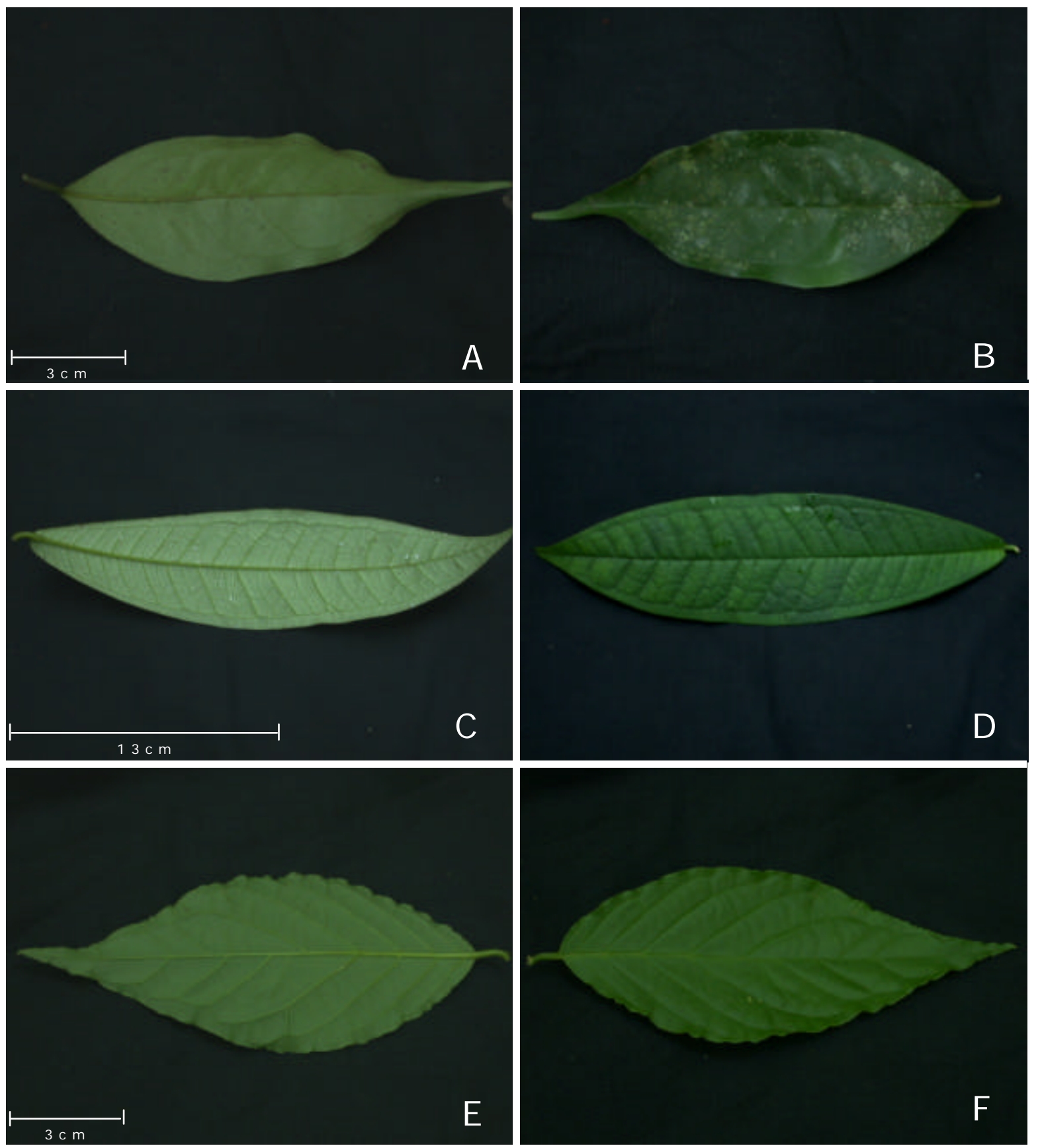

Figura 7 - Folhas de espécies de Myrtaceae ocorrentes no Parque Estadual Carlos Botelho: A. Calycorectes australis - face inferior; B. C. australis - face superior; C. Calyptranthes lanceolata - face inferior; D. C. lanceolata - face superior; E. Campomanesia guaviroba - face inferior; F. C. guaviroba - face superior 

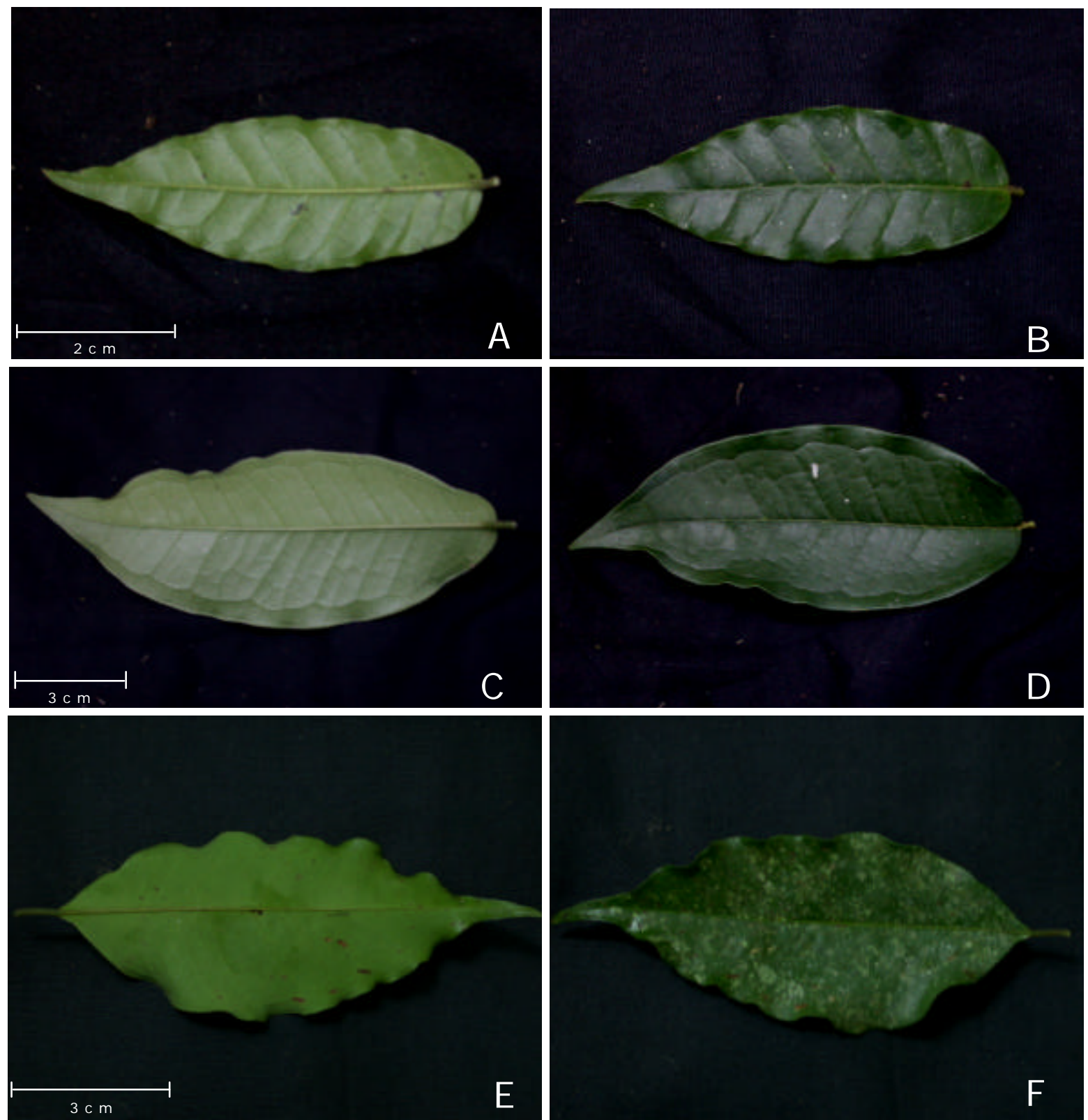

Figura 8 - Folhas de espécies de Myrtaceae ocorrentes no Parque Estadual Carlos Botelho: A. Campomanesia sp. - face inferior; B. Campomanesia sp. - face superior; C. Eugenia bacopari - face inferior; D. E. bacopari - face superior; E. E. beaurepaireana - face inferior; F. E. beaurepaireana - face superior 


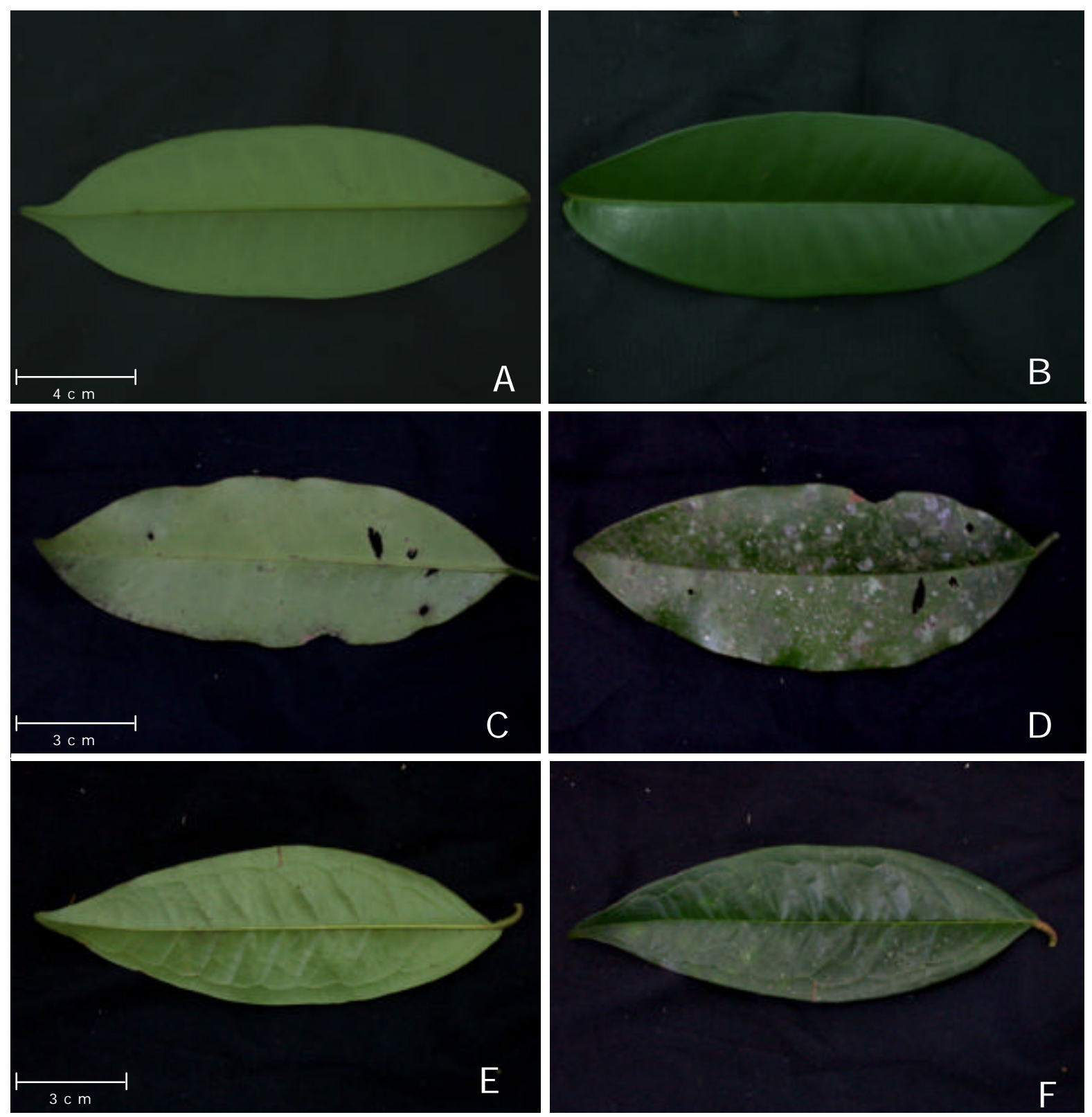

Figura 9 - Folhas de espécies de Myrtaceae ocorrentes no Parque Estadual Carlos Botelho: A. E. bocainensis - face inferior; B. E. bocainensis - face superior; C. E. bunchosiifolia - face inferior; D. E. bunchosiifolia - face superior; E. E. cf. burkartiana - face inferior; F. E. cf. burkartiana - face superior 

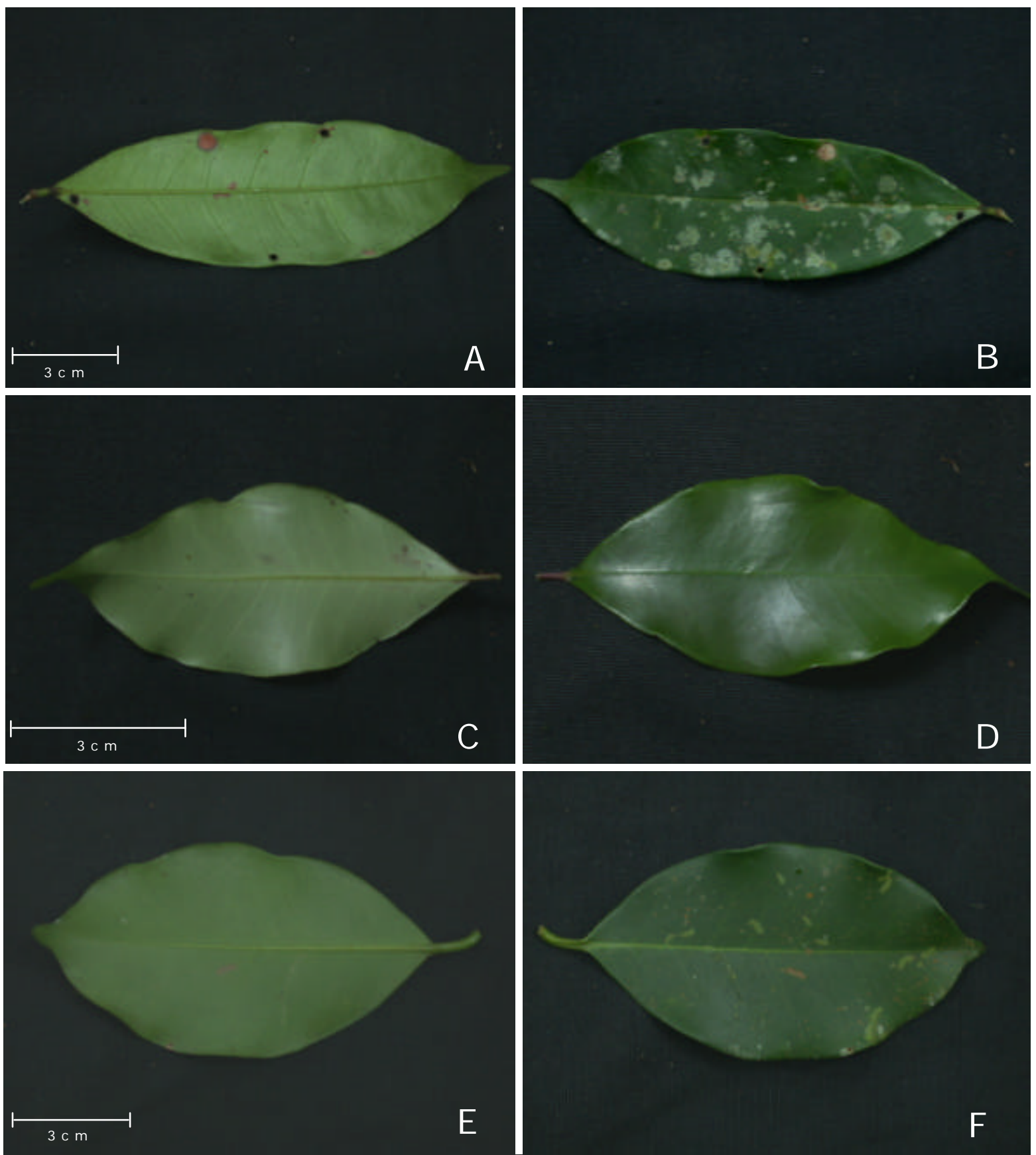

Figura 10 - Folhas de espécies de Myrtaceae ocorrentes no Parque Estadual Carlos Botelho: A. Eugenia cambucarana - face inferior; B. E. cambucarana - face superior; C. E. capitulifera - face inferior; D. E. capitulifera - face superior; E. E. cerasiflora - face inferior; F. E. cerasiflora - face superior 

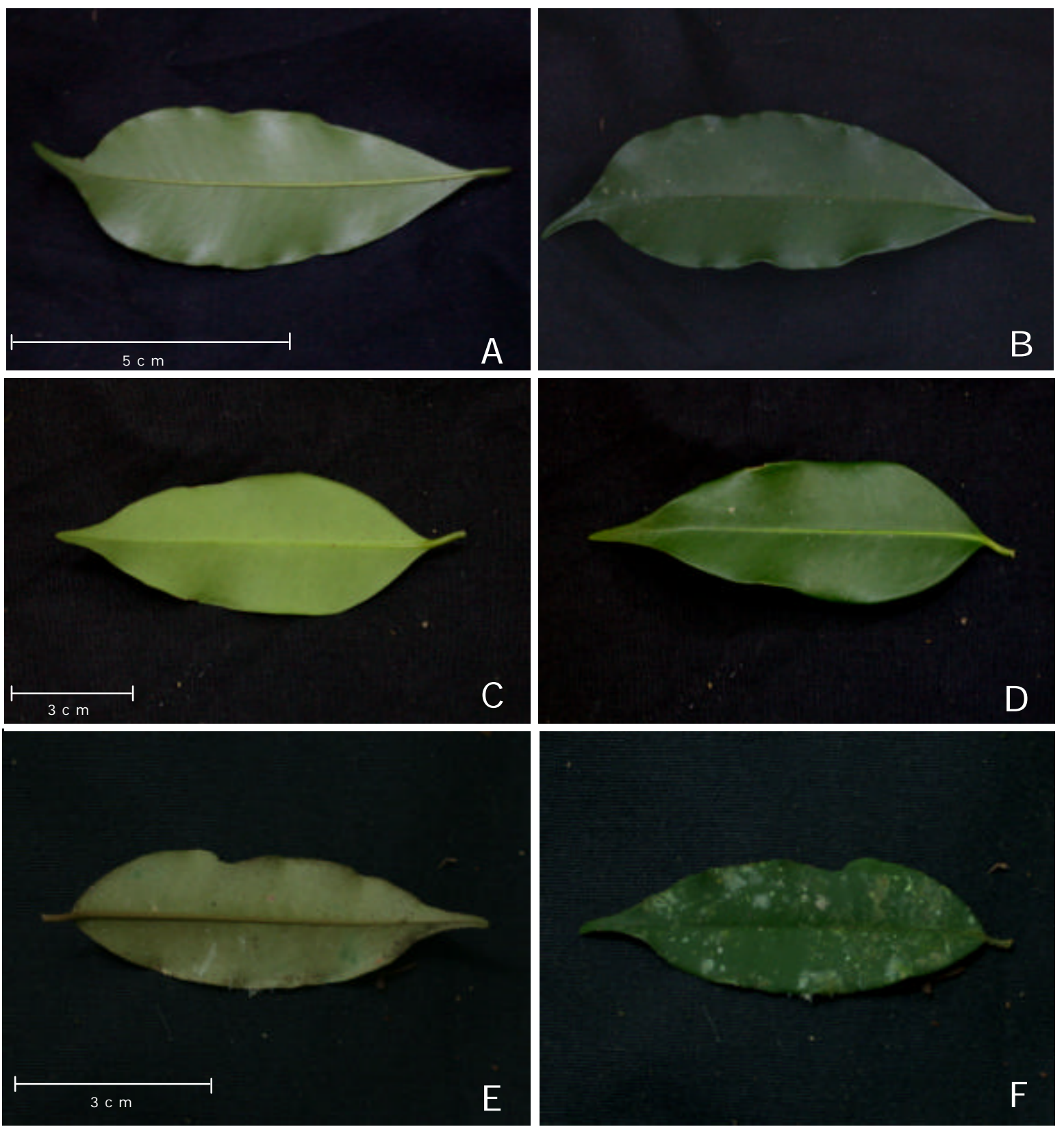

Figura 11 - Folhas de espécies de Myrtaceae ocorrentes no Parque Estadual Carlos Botelho: A. Eugenia cereja - face inferior; B. E. cereja - face superior; C. E. copacabanensis - face inferior; D. E. copacabanensis - face superior; E. E. cuprea - face inferior; F. E. cuprea - face superior 

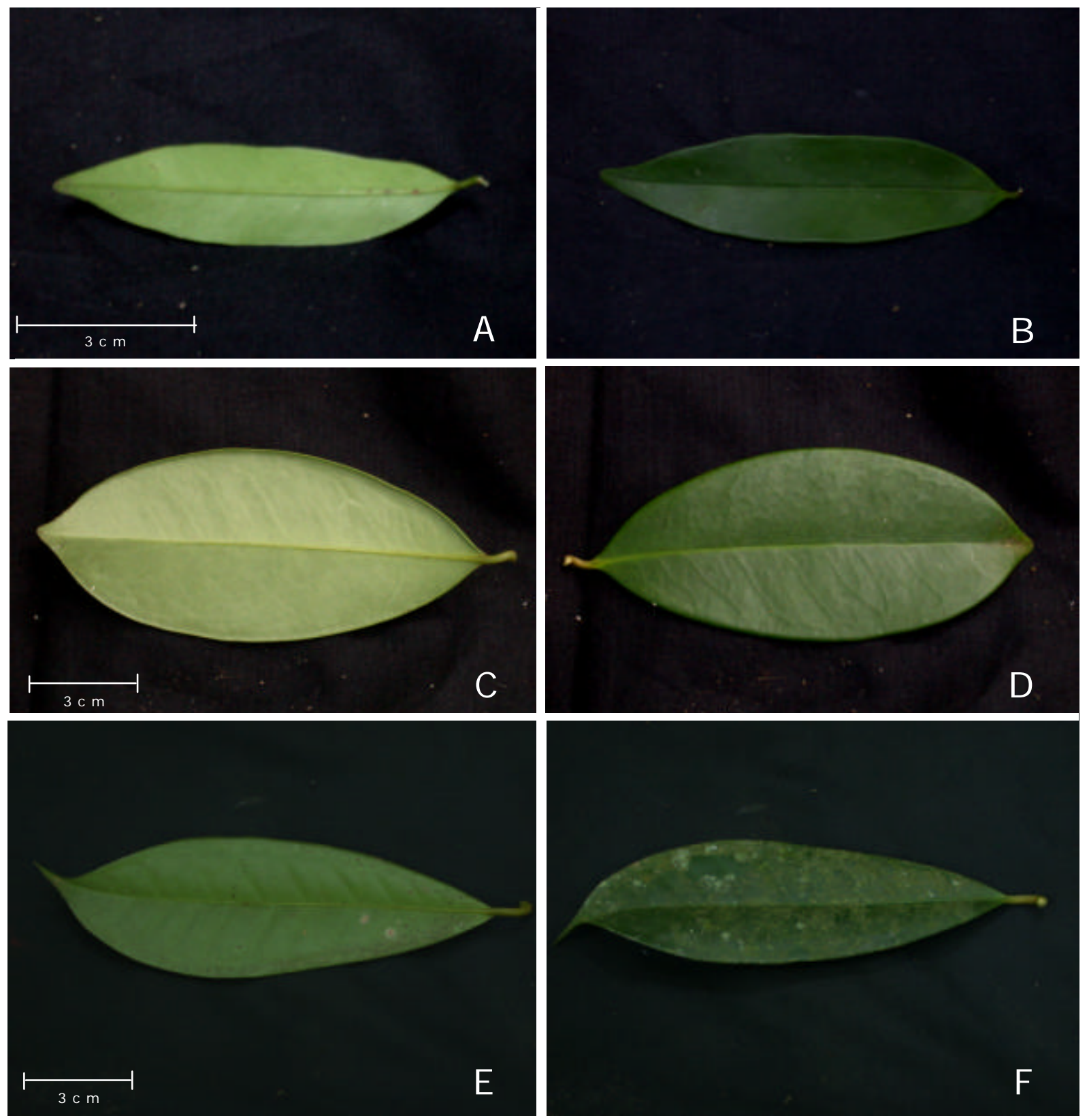

Figura 12 - Folhas de espécies de Myrtaceae ocorrentes no Parque Estadual Carlos Botelho: A. Eugenia handroana - face inferior; B. E. handroana - face superior; C. E. melanogyna - face inferior; D. E. melanogyna - face superior; E. E. mosenii - face inferior; F. E. mosenii - face superior 

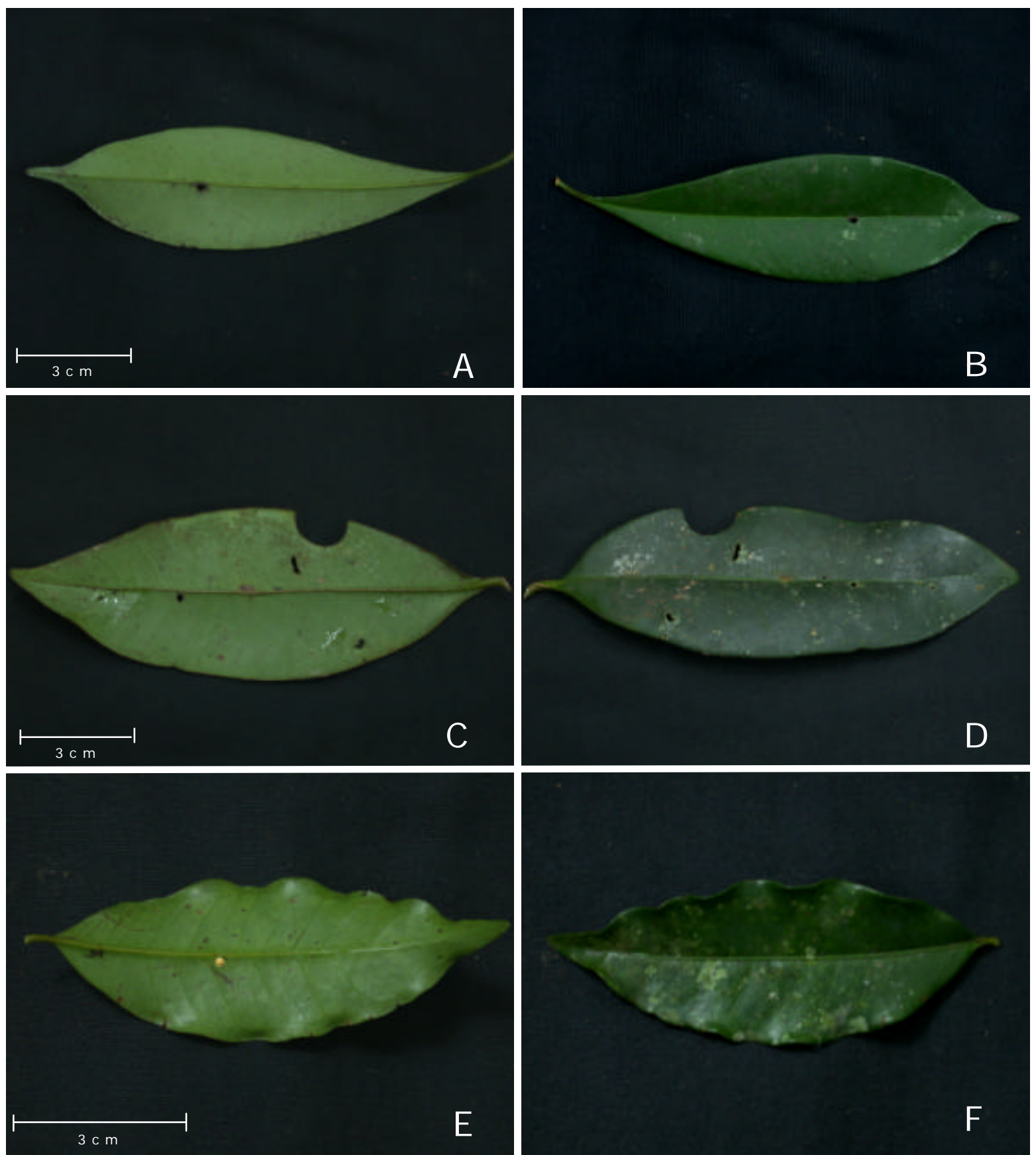

Figura 13 - Folhas de espécies de Myrtaceae ocorrentes no Parque Estadual Carlos Botelho: A. Eugenia multicostata - face inferior; B. E. multicostata - face superior; C. E. neoglomerata - face inferior; D. E. neoglomerata - face superior; E. E. neoverrucosa - face inferior; F. E. neoverrucosa - face superior 

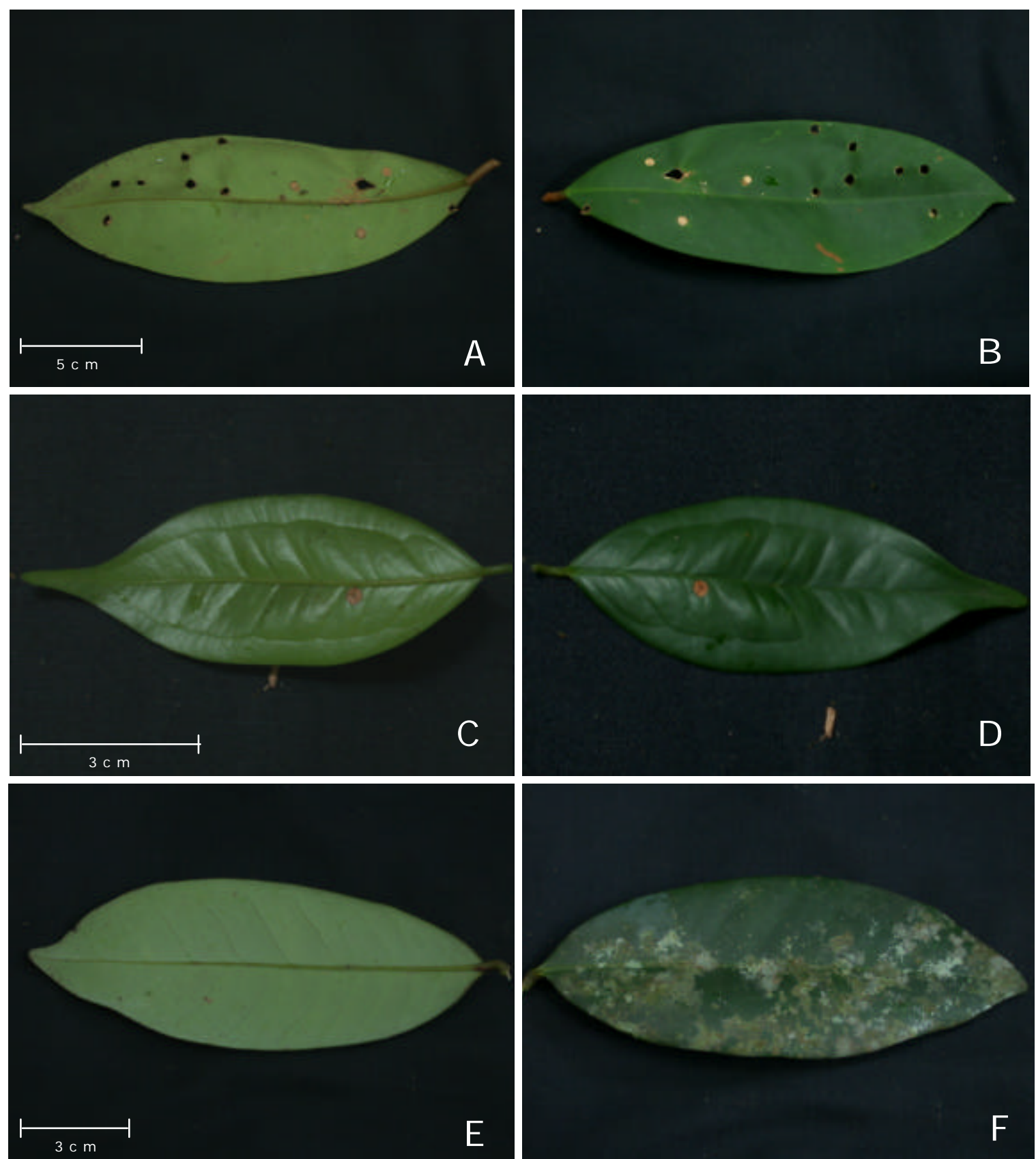

Figura 14 - Folhas de espécies de Myrtaceae ocorrentes no Parque Estadual Carlos Botelho: A. Eugenia oblongata - face inferior; B. E. oblongata - face superior; C. E. platysema - face inferior; D. E. platysema - face superior; E. E. pruinosa - face inferior; F. E. pruinosa - face superior 

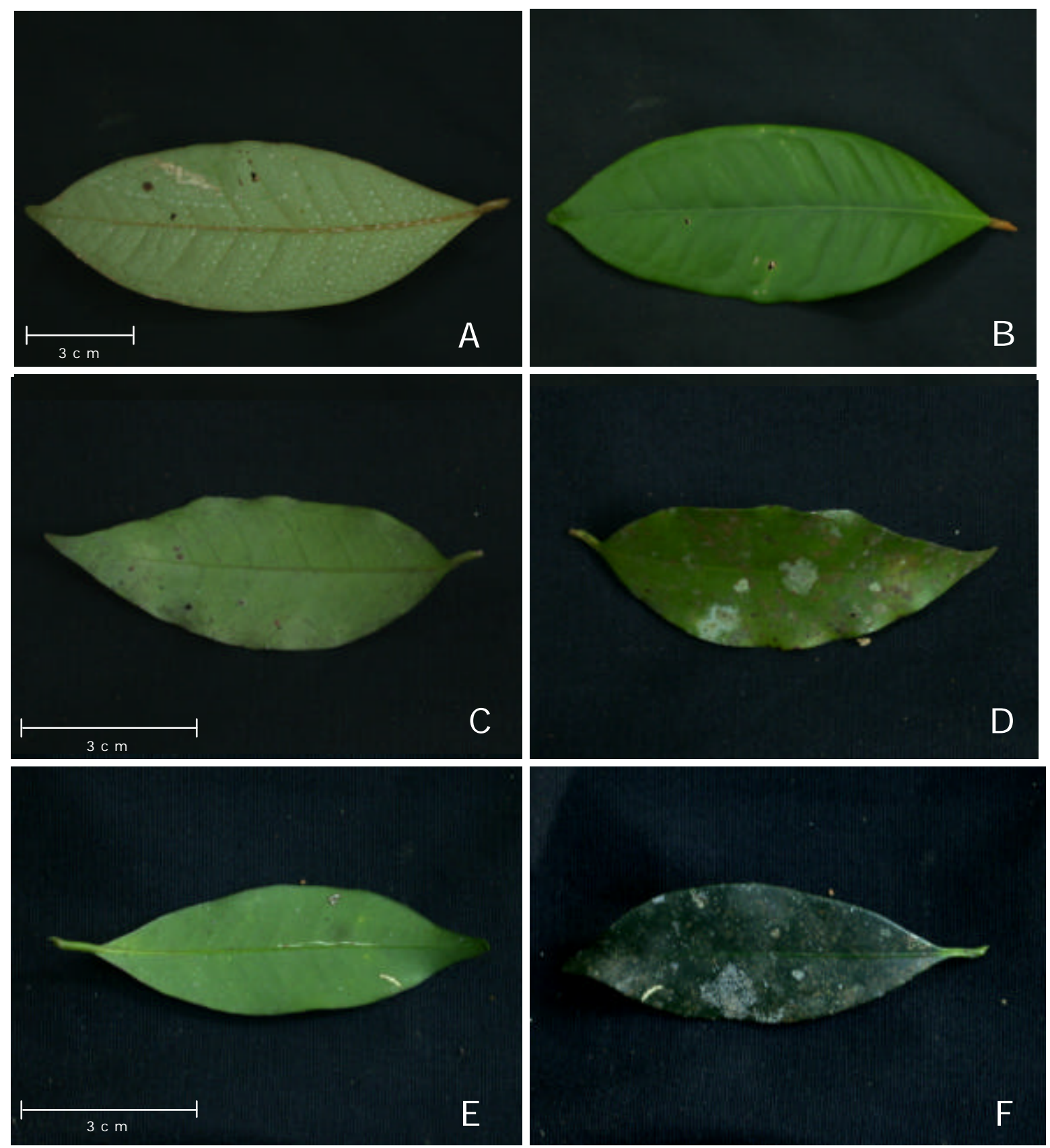

Figura 15 - Folhas de espécies de Myrtaceae ocorrentes no Parque Estadual Carlos Botelho: A. Eugenia riedeliana - face inferior; B. E. riedeliana - face superior; C. E. schuechiana - face inferior; D. E. schuechiana - face superior; E. E. stictosepala - face inferior; F. E. stictosepala - face superior 

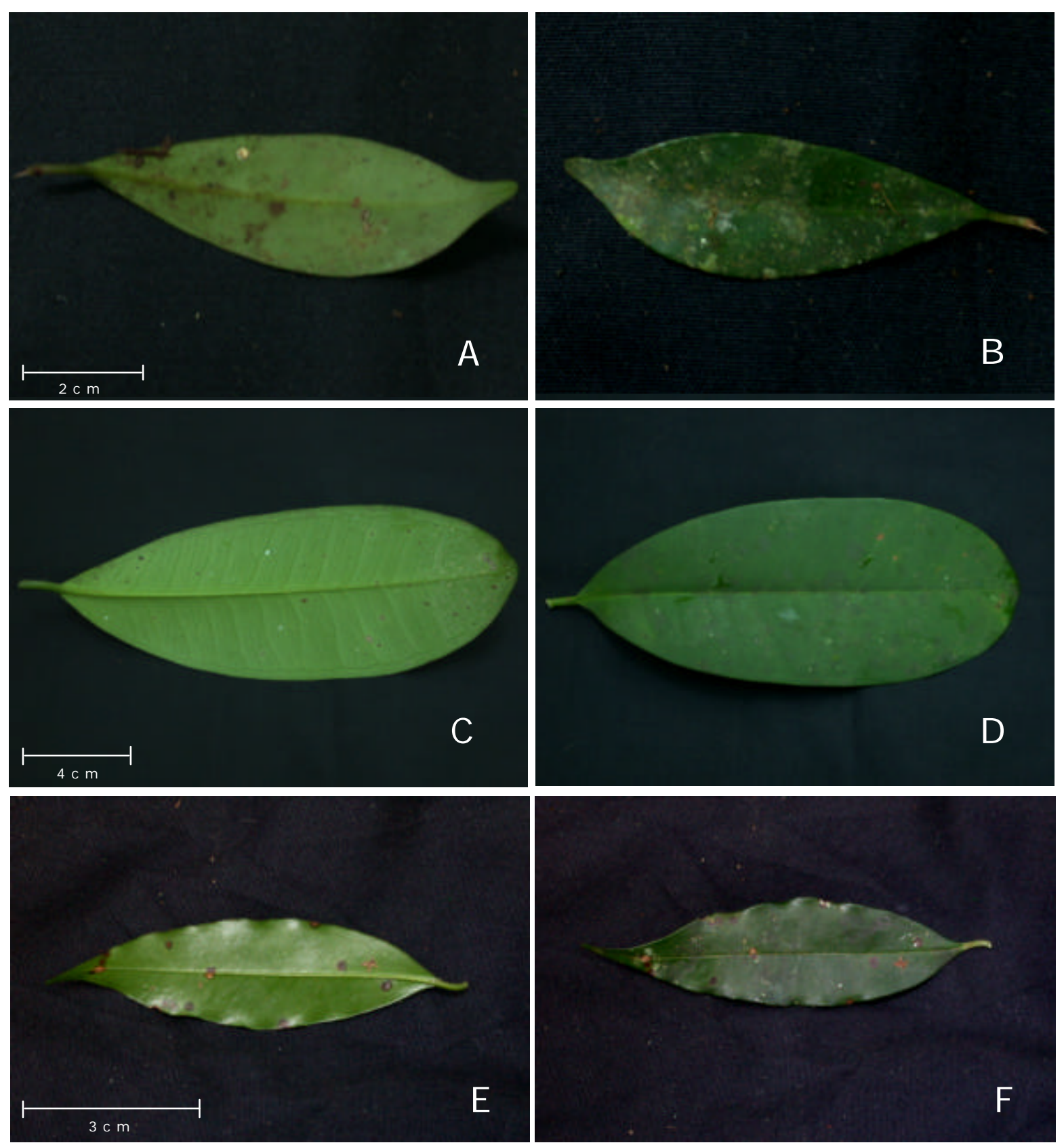

Figura 16 - Folhas de espécies de Myrtaceae ocorrentes no Parque Estadual Carlos Botelho: A. Eugenia subavenia - face inferior; B. E. subavenia - face superior; C. E. xiriricana - face inferior; D. E. xiriricana - face superior; E. Eugenia sp. - face inferior; F. Eugenia sp. - face superior 


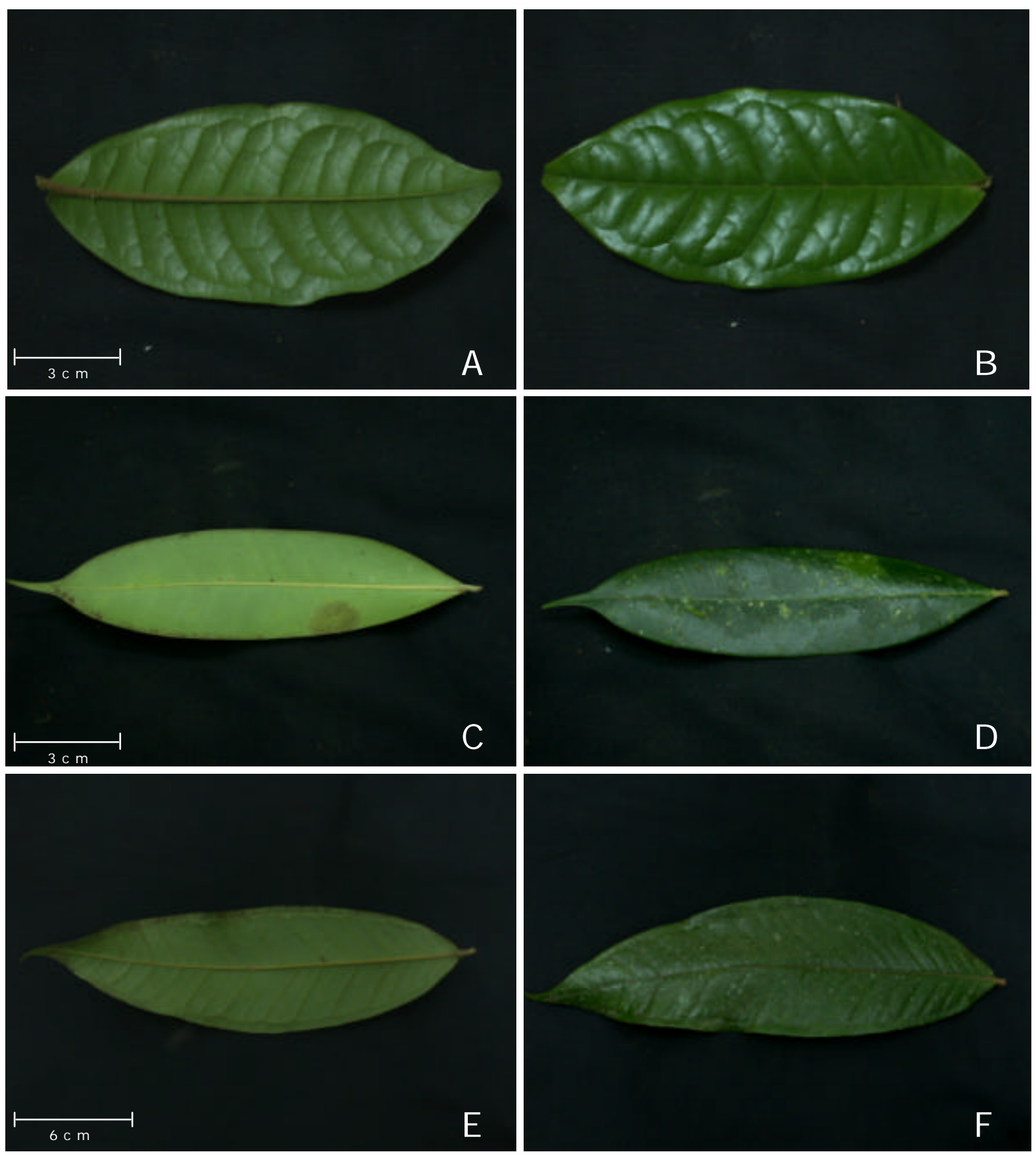

Figura 17 - Folhas de espécies de Myrtaceae ocorrentes no Parque Estadual Carlos Botelho: A. Gomidesia anacardiaefolia - face inferior; B. G. anacardiaefolia - face superior; C. G. flagellaris - face inferior; D. G. flagellaris - face superior; E. G. spectabilis - face inferior; F. G. spectabilis - face superior 

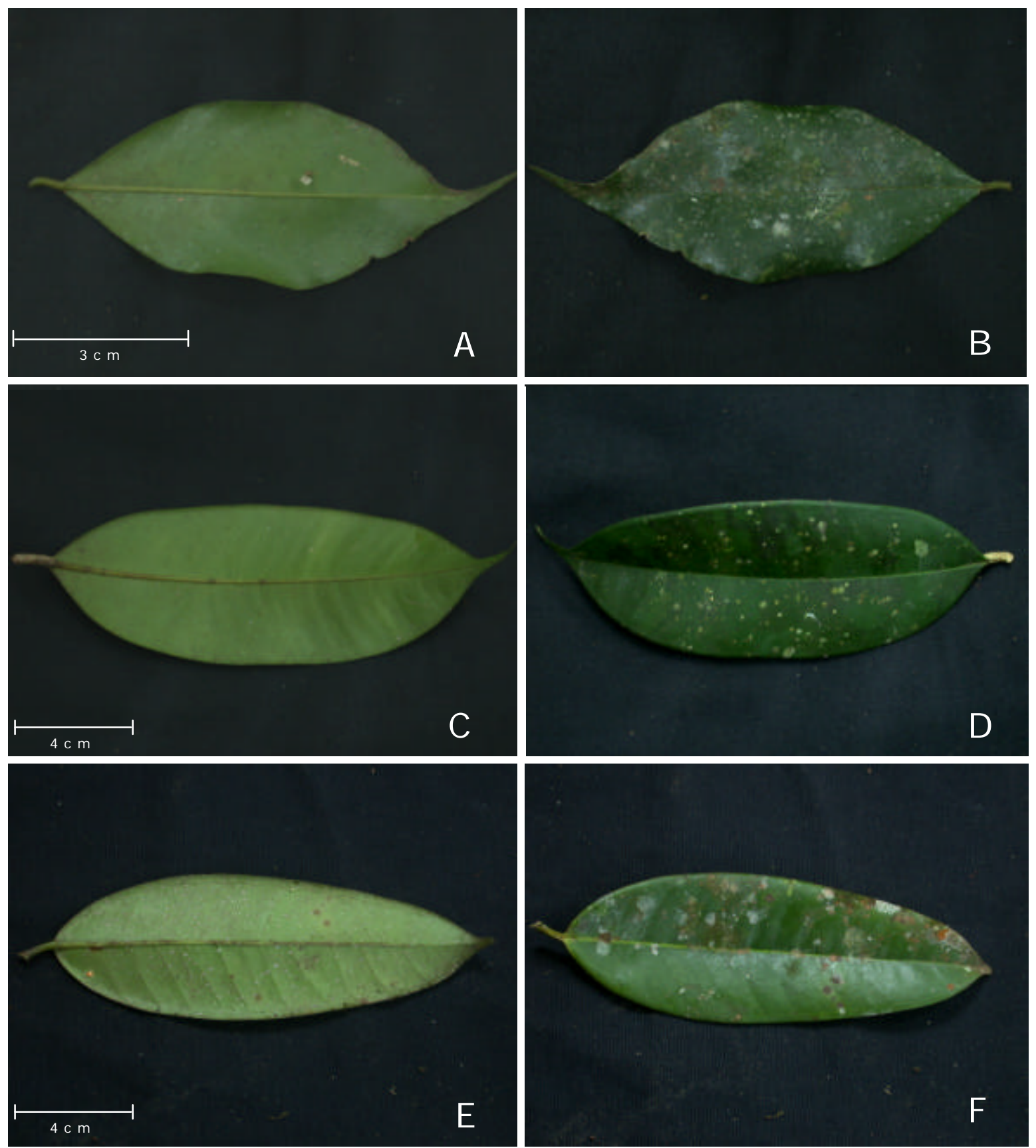

Figura 18 - Folhas de espécies de Myrtaceae ocorrentes no Parque Estadual Carlos Botelho: A. Gomidesia tijucensis - face inferior; B. G. tijucensis - face superior; C. Marlierea eugeniopsoides - face inferior; D. M. eugeniopsoides face superior; E. M. obscura - face inferior; F. M. obscura - face superior 

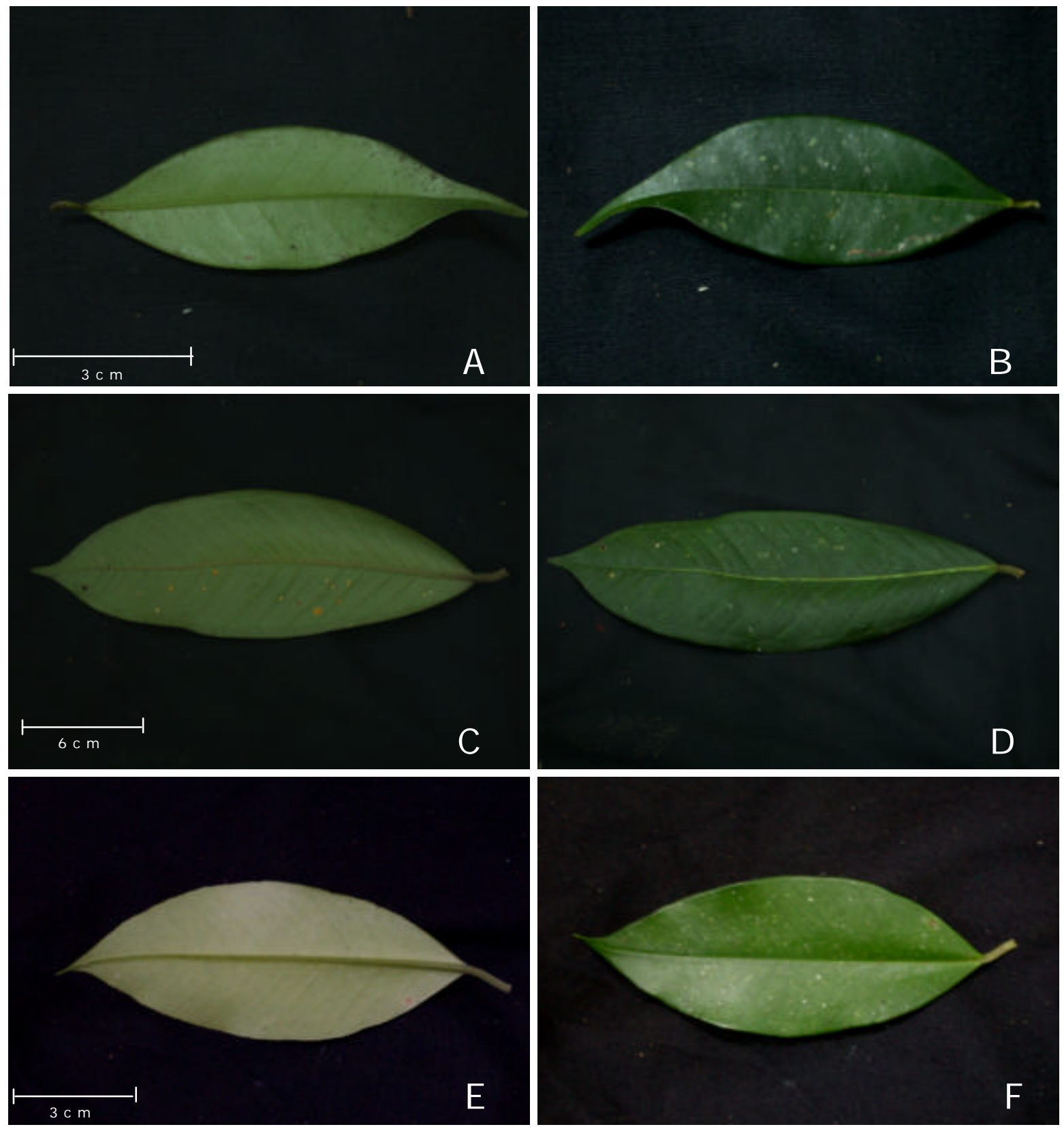

Figura 19 - Folhas de espécies de Myrtaceae ocorrentes no Parque Estadual Carlos Botelho: A. Marlierea suaveolens - face inferior; B. M. suaveolens - face superior; C. Marlierea tomentosa - face inferior; D. M. tomentosa - face superior; E. Myrceugenia kleinii - face inferior; F. M. kleinii - face superior 

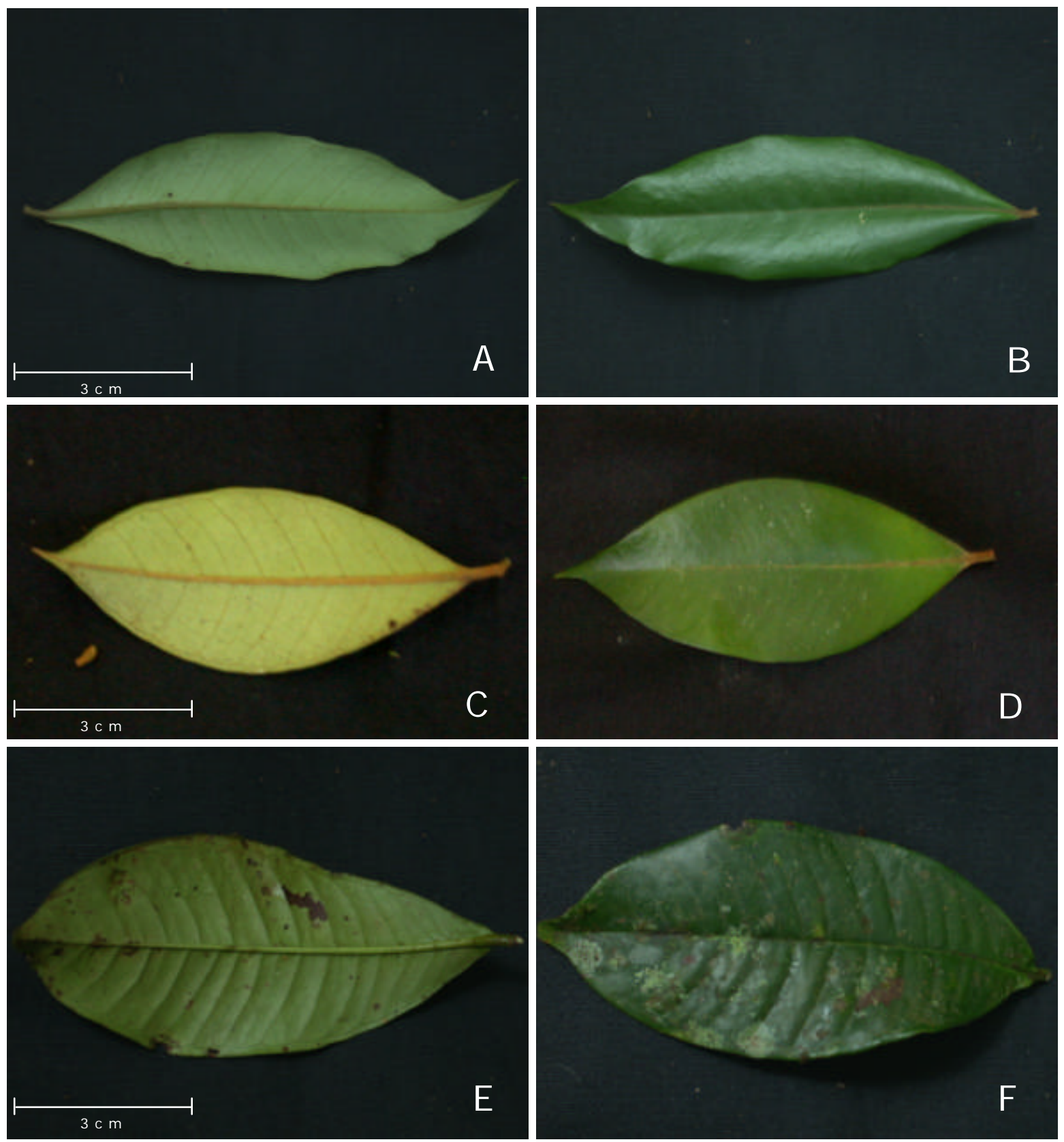

Figura 20 - Folhas de espécies de Myrtaceae ocorrentes no Parque Estadual Carlos Botelho: A. Myrceugenia myrcioides - face inferior; B. M. myrcioides - face superior; C. Myrceugenia pilotantha - face inferior; D. M. pilotantha - face superior; E. Myrcia aff. freyreissiana - face inferior; F. M. aff. freyreissiana - face superior 


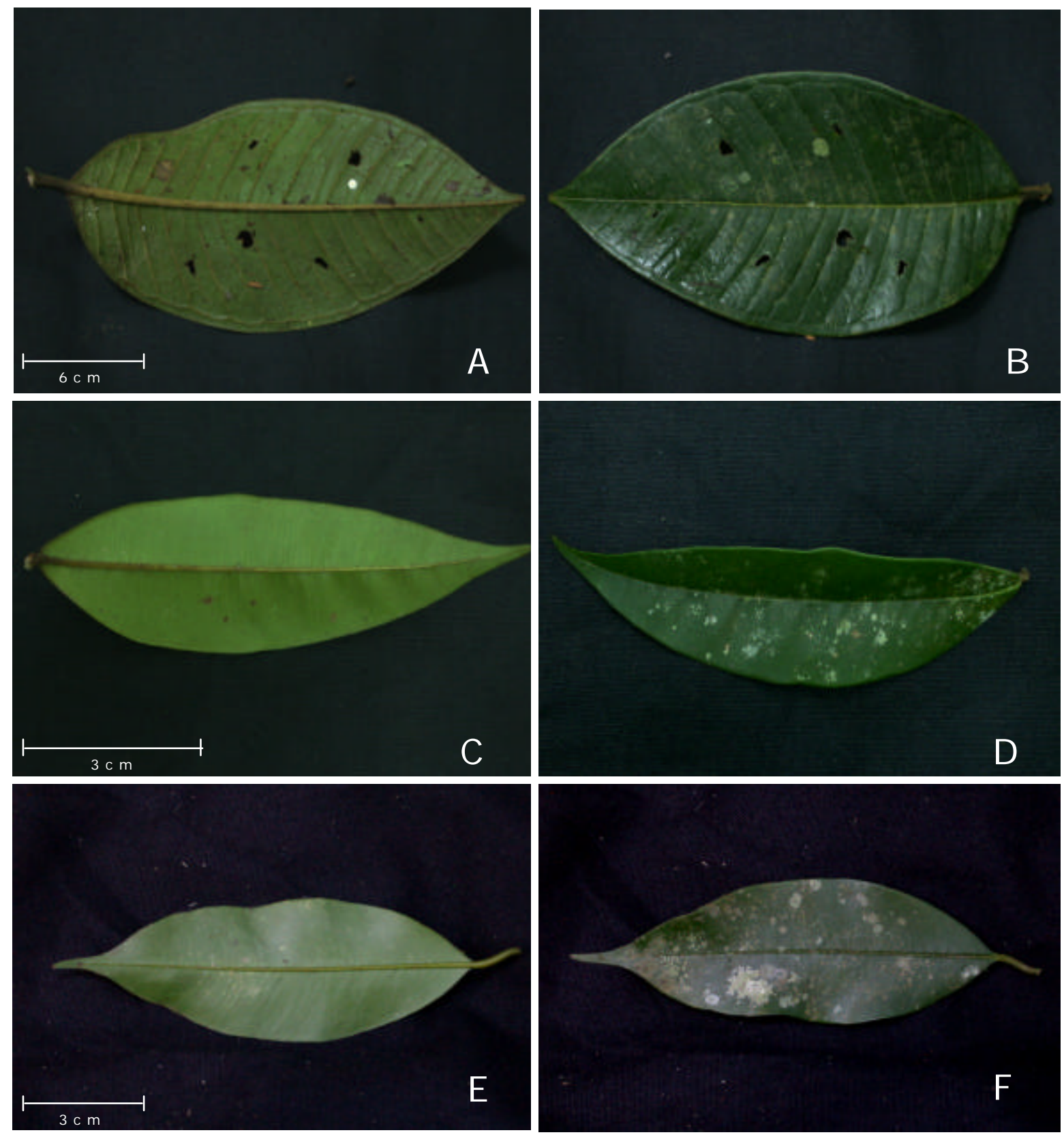

Figura 21 - Folhas de espécies de Myrtaceae ocorrentes no Parque Estadual Carlos Botelho: A. Myrcia pubipetala - face inferior; B. M. pubipetala - face superior; C. Myrcia tenuivenosa - face inferior; D. M. tenuivenosa - face superior; E. Myrciaria cf. floribunda - face inferior; F. M. cf. floribunda - face superior 

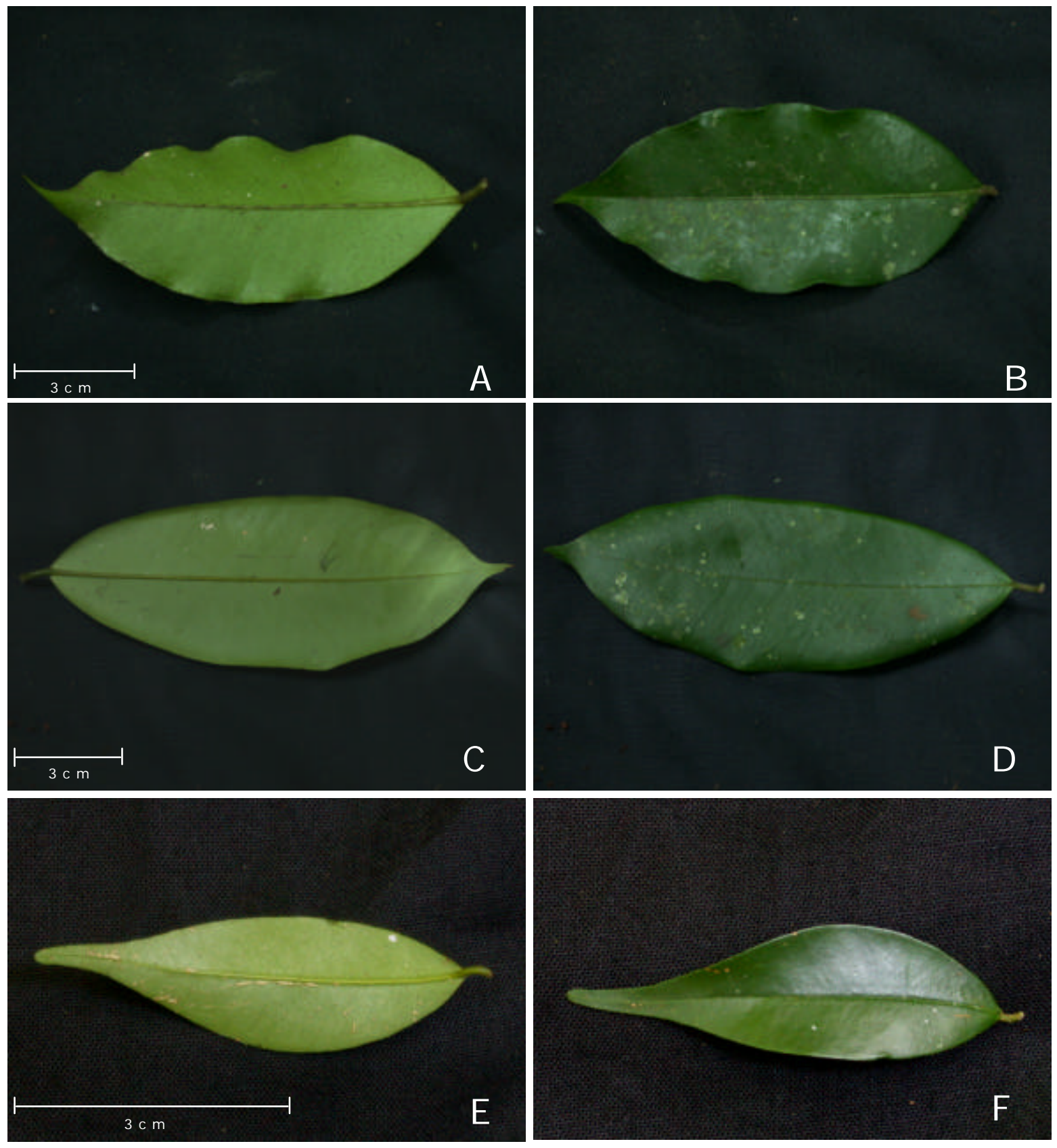

Figura 22 - Folhas de espécies de Myrtaceae ocorrentes no Parque Estadual Carlos Botelho: A. Neomitranthes glomerata - face inferior; B. Neomitranthes glomerata - face superior; C. Plinia complanata - face inferior; D. P. complanata - face superior; E. Plinia pauciflora - face inferior; F. P. pauciflora - face superior 


\subsection{TRONCO}

Muitas vezes associa-se às espécies da família Myrtaceae, troncos que possuam uma intensa descamação da camada mais externa (ritidoma), tornando-os bastante lisos, como ocorre em Psidium guajava L. (goiabeira) e Myrciaria cauliflora O. Berg (jabuticabeira). Embora isso também ocorra em algumas espécies da floresta ombrófila densa baixo montana, não se trata de uma regra geral. Entre as espécies que apresentam essa característica, e por isso tem seu reconhecimento facilitado, podemos destacar Eugenia multicostata (Fig.23AB) com coloração avermelhada intensa e Marlierea suaveolens (Fig.23CD), que apresenta coloração verde. Estas espécies podem ser reconhecidas na área utilizando-se este caráter. Além disso, há espécies com tronco de tonalidade creme-esbranquiçada como Eugenia bacopari (Fig.23EF), Eugenia cf. burkartiana (Fig.24AB), Marlierea obscura (Fig.24CD) e Myrciaria cf. floribunda (Fig.24EF). Espécies de tonalidade avermelhada foram observadas em $M$. aff. freyreissiana (Fig.25AB), Plinia complanata (Fig.25CD) e Plinia pauciflora (Fig.25EF), porém não tão intensa como em E. multicostata. No caso de Plinia pauciflora (Fig.25EF), destacam-se as descamações circulares que se assemelham aos troncos de Cryptocarya moschata Ness. Algumas espécies, mais intensamente do que outras, apresentam o tronco geralmente revestido por musgos, liquens e briófitas como: Eugenia riedeliana (Fig.26AB), Eugenia schuechiana (Fig.26CD) e Myrcia pubipetala (Fig.26EF), o que não foi suficientemente investigado no que se refere ao uso deste caráter com objetivos taxonômicos. As características internas e macroscópicas da madeira também podem ser úteis no reconhecimento das espécies, particularmente no que se refere à coloração, que varia desde uniformemente rosada, bege, vinho, creme- 
avermelhada até alaranjada. Entretanto, considerando que a descrição da coloração pode carregar um alto grau de subjetividade, utilizourse este caráter somente como uma ferramenta auxiliar na identificação das espécies. De qualquer forma, em determinadas espécies a coloração interna é mais marcante, podendo auxiliar de forma mais objetiva, como ocorre em Calyptranthes lanceolata (Fig.27AB) e Eugenia handroana (Fig.27CD), ambas de coloração vinho intensa. Também pode ser destacada a alternância entre estrias vinhos e brancas apresentadas por Eugenia neoverrucosa (Fig.27EF). No desenvolvimento do trabalho constatou-se também variações nas colorações internas e externas entre indivíduos jovens e adultos de uma mesma espécie. Este fato foi observado, por exemplo, em Eugenia xiriricana jovem (Fig.28AB) e adulta (Fig.28CD). Outra característica notada em relação aos troncos, é que algumas espécies possuem logo após a camada mais externa uma ou mais camadas delgadas assemelhando-se a folhas de papel, como ocorre em Campomanesia guaviroba (Fig.28EF), Campomanesia sp. (Fig.29AB), Eugenia cereja (Fig.29CD) e Eugenia oblongata (Fig.29EF), entre outras. Por fim, determinados troncos possuem características externas mais marcantes, como, por exemplo, Eugenia bocainensis (Fig.30AB) com casca profundamente fendida longitudinalmente, ou mesmo Eugenia cambucarana (Fig.30CD) e Eugenia cuprea (Fig.30EF), com estrias menos profundas. $\mathrm{O}$ aspecto "quadriculado" apresentado por Eugenia pruinosa (Fig.31AB), associado à sua coloração interna rosa-claro também merece destaque. Porém, para algumas espécies, tanto o aspecto externo quanto o interno são semelhantes, impossibilitando sua diferenciação quando estas características são utilizadas isoladamente, como foi observado no campo em Eugenia bacopari, Eugenia cf. burkartiana e Myrciaria cf. 
floribunda, assim como entre Eugenia melanogyna (Fig.31CD) e Eugenia mosenii (Fig.31EF).

De modo geral, pode-se observar uma semelhança principalmente no aspecto externo entre os troncos do gênero Gomidesia, como em Gomidesia anacardiaefolia (Fig.32AB), Gomidesia spectabilis (Fig.32CD) e Gomidesia tijucensis (Fig.32EF), sendo que o mesmo não ocorreu de forma tão notória nos demais gêneros.

\section{$4.3 \underline{\text { RAMOS }}$}

De uma forma geral, os ramos apresentam características que foram pouco úteis no reconhecimento das espécies, exceto em alguns casos específicos, como em Plinia complanata (Fig.6B), que possui ramos jovens fortemente achatados, ao passo que na maioria das espécies os ramos terminais são apenas ligeiramente achatados. Outro caso que merece destaque é o de Marlierea tomentosa (Fig.5B), com ramificação pseudodicotômica bastante característica. A coloração dos ramos jovens, também pode ser útil em alguns poucos casos, como em Eugenia bunchosiifolia (Fig.1H), Eugenia cerasiflora (Fig.2C) e Eugenia handroana (Fig.2G) que apresentam ramos jovens com coloração vermelha bastante marcante. Nos demais casos a coloração dos ramos varia entre castanho-claro e castanho-escuro, às vezes mais ou menos acinzentados. Eugenia riedeliana (Fig.3G) é a única espécie que apresenta em seus ramos jovens um indumento ferrugíneo-tomentoso que se desprende com facilidade. Outra característica útil taxonomicamente é a presença de ramos fistulosos, observados em Eugenia melanogyna (Fig.2H) e Eugenia mosenii (Fig.2I), porém mais nitidamente na primeira, na qual os ramos chegam a ser mais leves do que os de outras espécies. A presença de ritidomas 
que se destacam nos ramos mais velhos e troncos é uma característica comum entre as Myrtaceae, entretanto, poucas espécies apresentam ritidomas que se destacam nos ramos jovens, e isto pode ser encontrado na área em Eugenia multicostata(Fig.3A), Marlierea obscura (Fig.4I) e Myrcia aff. freyreissiana (Fig.5F), sendo uma boa característica auxiliar para o reconhecimento destas espécies. 


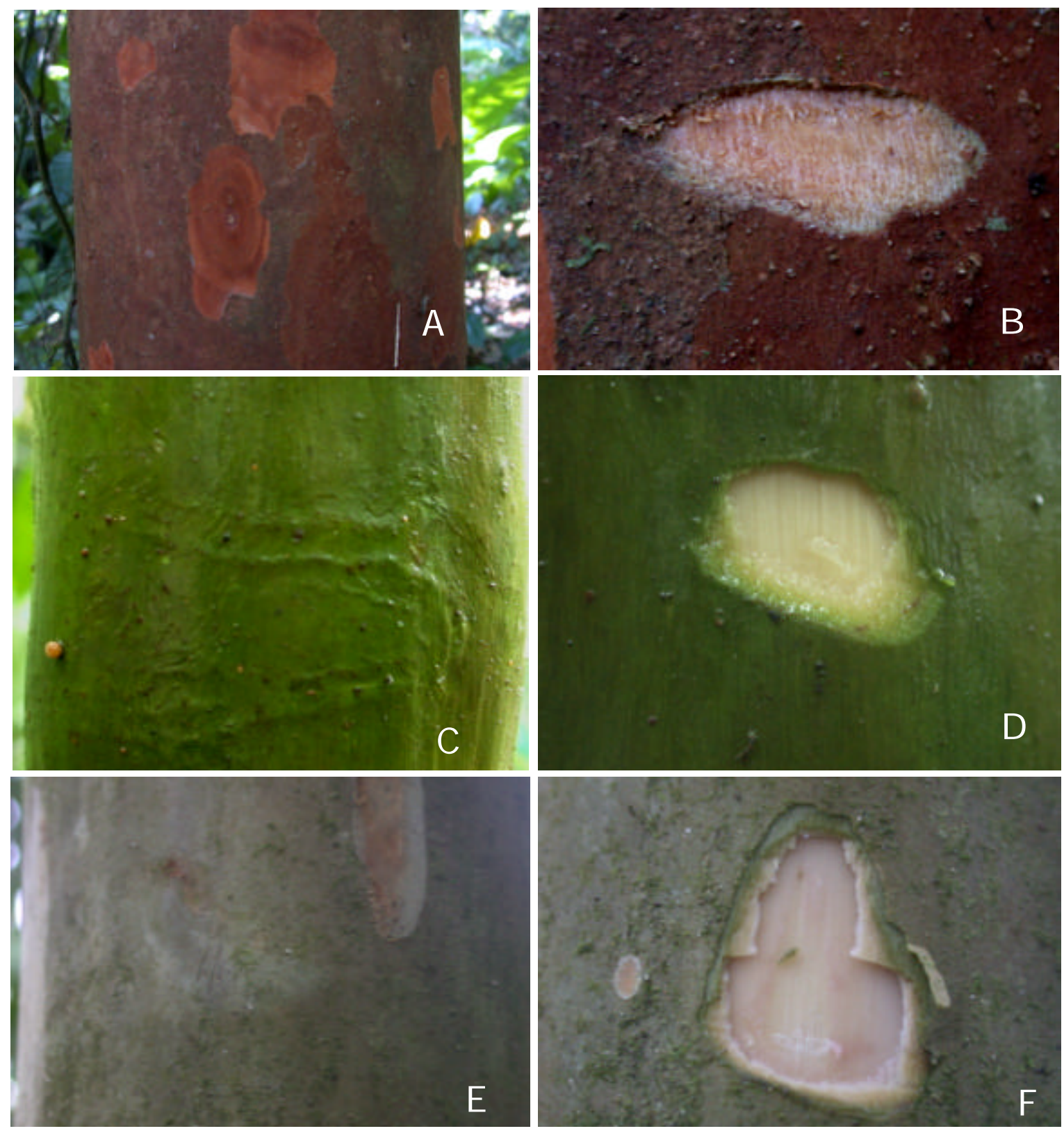

Figura 23 - Troncos de espécies de Myrtaceae ocorrentes no Parque Estadual Carlos Botelho: A. Eugenia multicostata - aspecto externo; B. E. multicostata aspecto interno; C. Marlierea suaveolens - aspecto externo; D. M. suaveolens - aspecto interno; E. Eugenia bacopari - aspecto externo; F. E. bacopari aspecto interno 

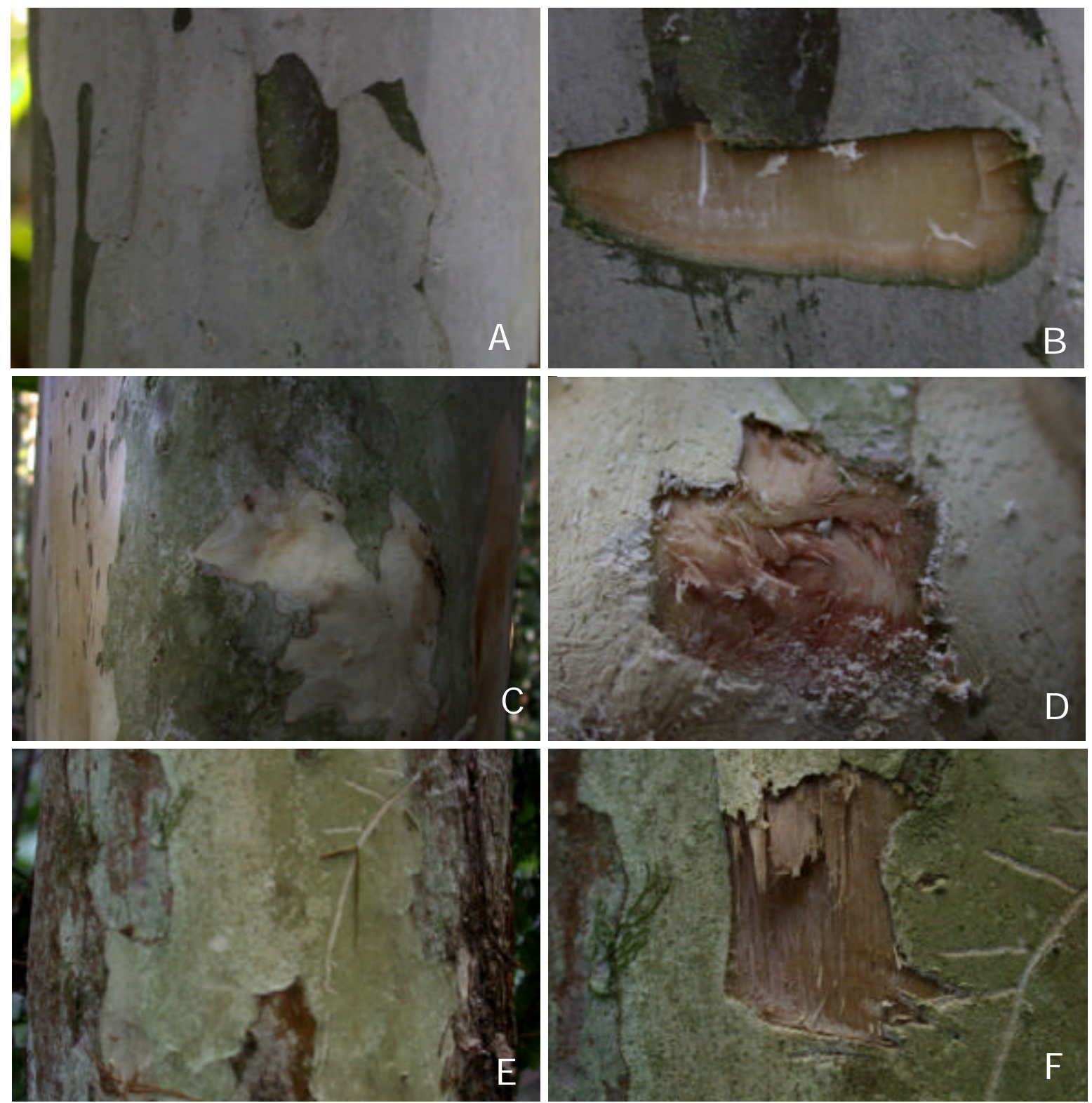

Figura 24 - Troncos de espécies de Myrtaceae ocorrentes no Parque Estadual Carlos Botelho: A. Eugenia cf. burkartiana - aspecto externo; B. E. cf. burkartiana aspecto interno; C. Marlierea obscura - aspecto externo; D. M. obscura aspecto interno; E. Myrciaria cf. floribunda - aspecto externo; F. M. cf. floribunda - aspecto interno 

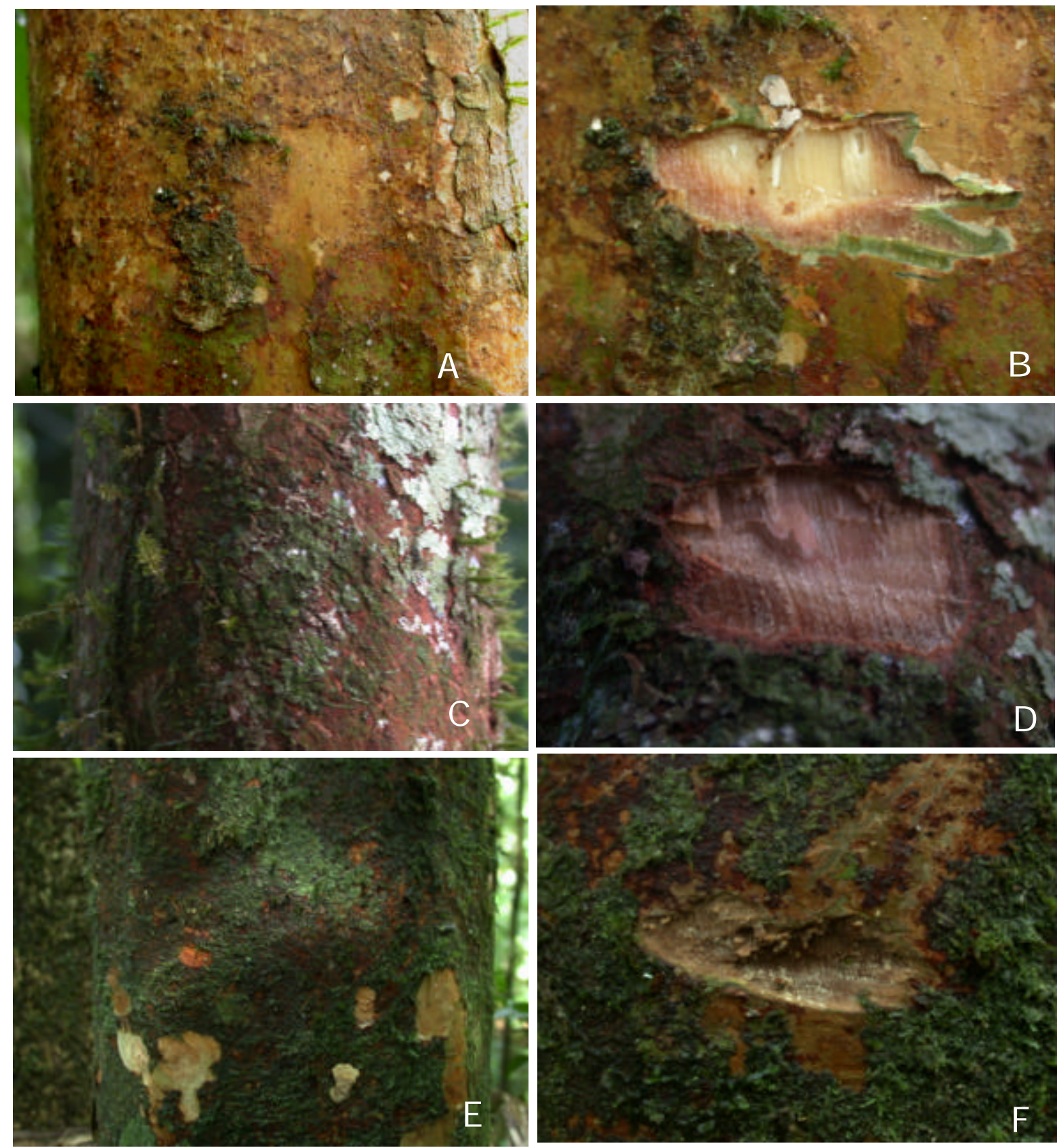

Figura 25 - Troncos de espécies de Myrtaceae ocorrentes no Parque Estadual Carlos Botelho: A. Myrcia aff. freyreissiana - aspecto externo; B. M. aff. freyreissiana - aspecto interno; C. Plinia complanata - aspecto externo; D. P. complanata aspecto interno; E. P. pauciflora - aspecto externo; F. P. pauciflora - aspecto interno 

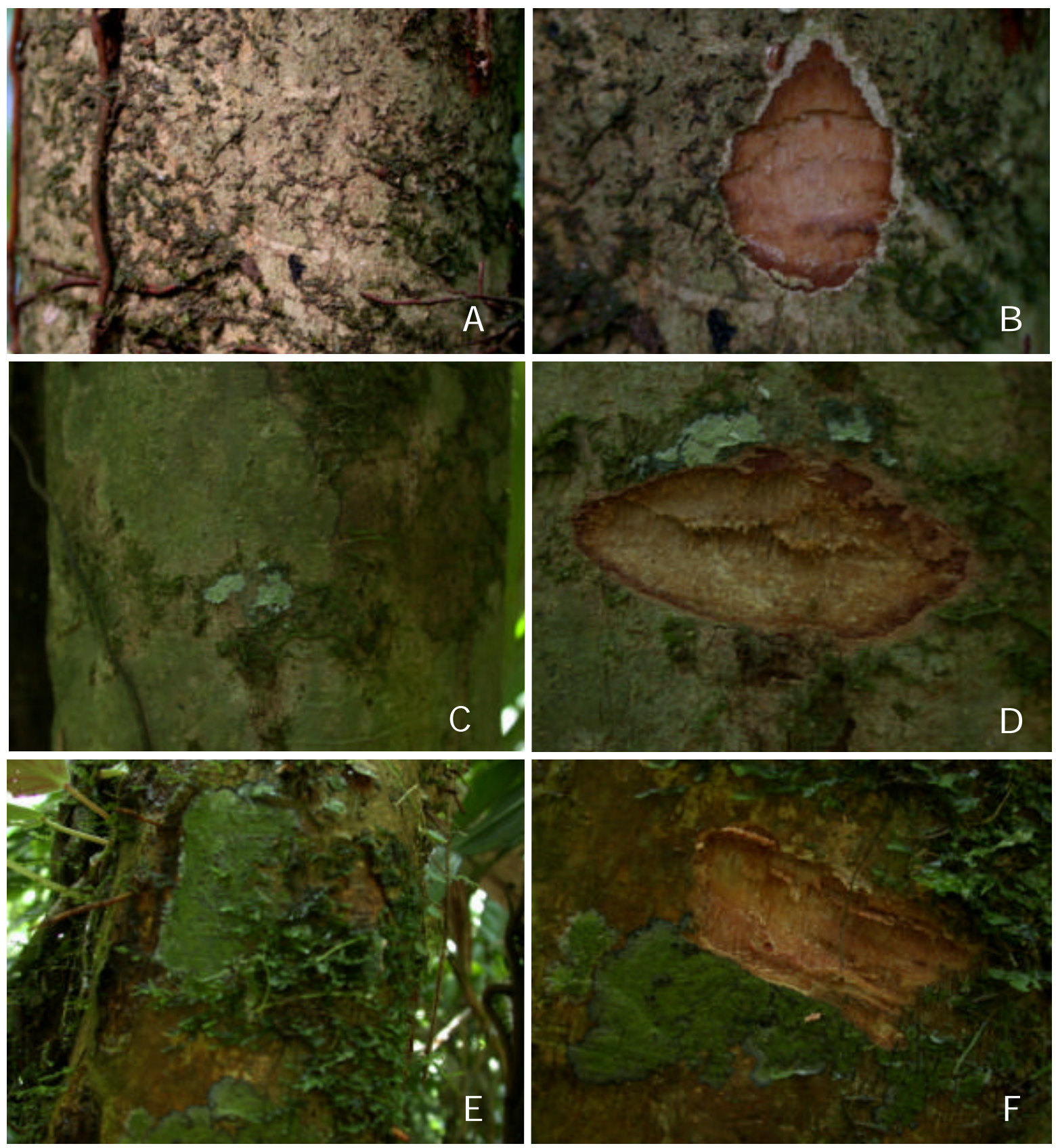

Figura 26 - Troncos de espécies de Myrtaceae ocorrentes no Parque Estadual Carlos Botelho: A. Eugenia riedeliana - aspecto externo; B. E. riedeliana - aspecto interno; C. E. schuechiana - aspecto externo; D. E. schuechiana - aspecto interno; E. Myrcia pubipetala - aspecto externo; F. M. pubipetala - aspecto interno 

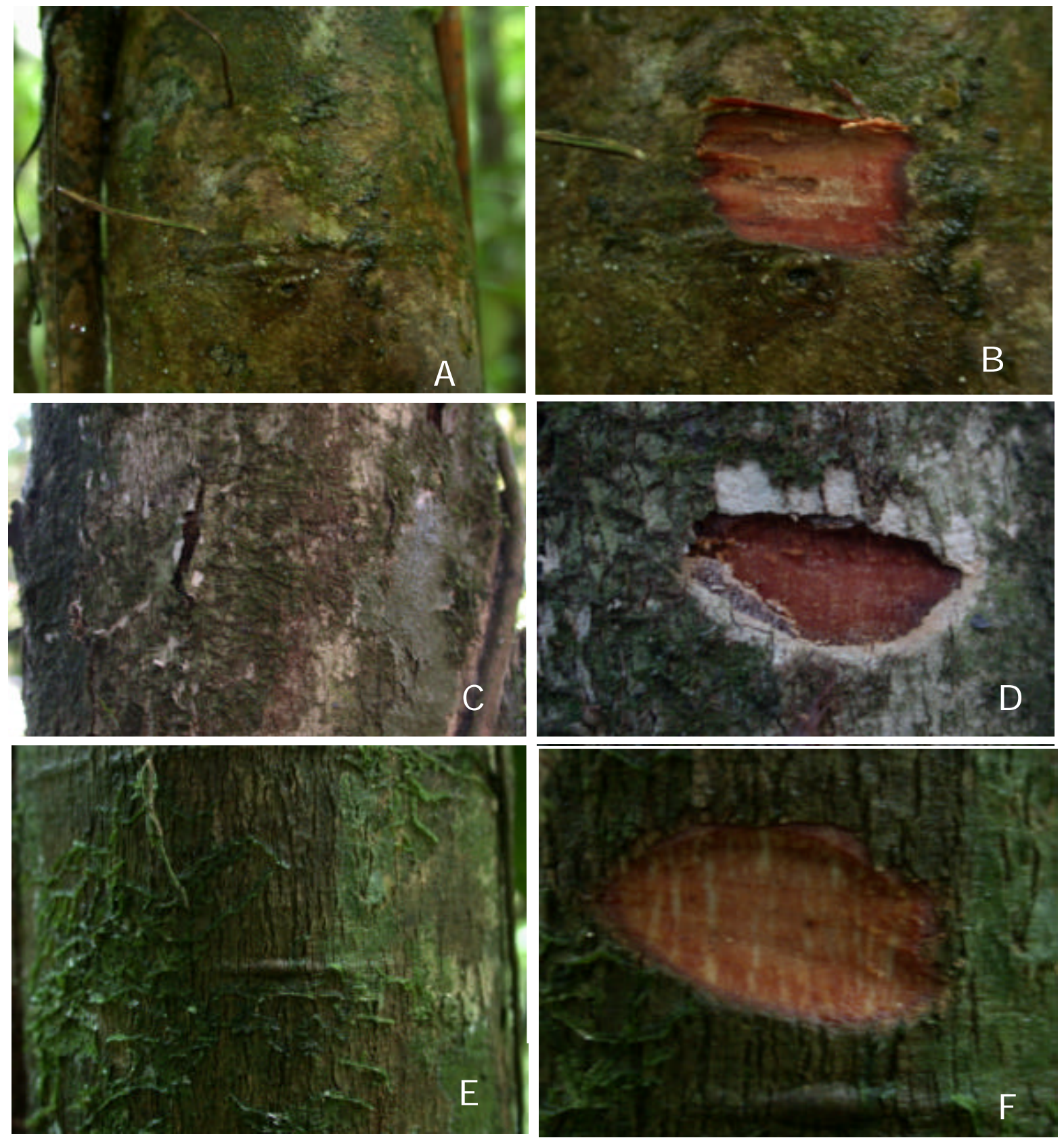

Figura 27 - Troncos de espécies de Myrtaceae ocorrentes no Parque Estadual Carlos Botelho: A. Calyptranthes lanceolata - aspecto externo; B. C. lanceolata aspecto interno; C. Eugenia handroana - aspecto externo; D. E. handroana aspecto interno; E. E. neoverrucosa - aspecto externo; F. E. neoverrucosa aspecto interno 

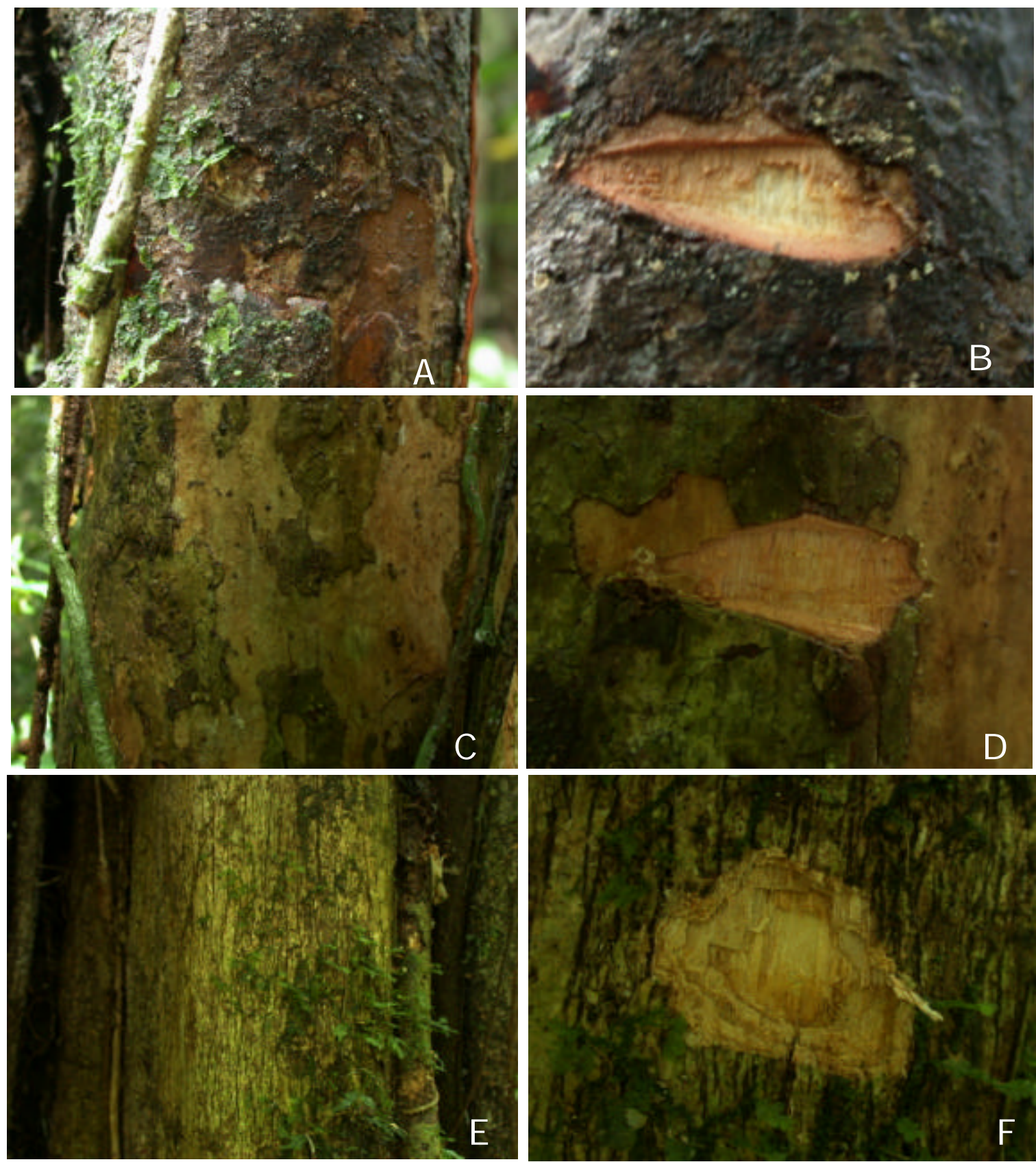

Figura 28 - Troncos de espécies de Myrtaceae ocorrentes no Parque Estadual Carlos Botelho: A. Eugenia xiriricana - (indivíduo jovem) aspecto externo; B. E. xiriricana - (indivíduo jovem) aspecto interno; C. E. xiriricana - (indivíduo adulto) aspecto externo; D. E. xiriricana - (indivíduo adulto) aspecto interno; E. Campomanesia guaviroba - aspecto externo; F. C. guaviroba - aspecto interno 

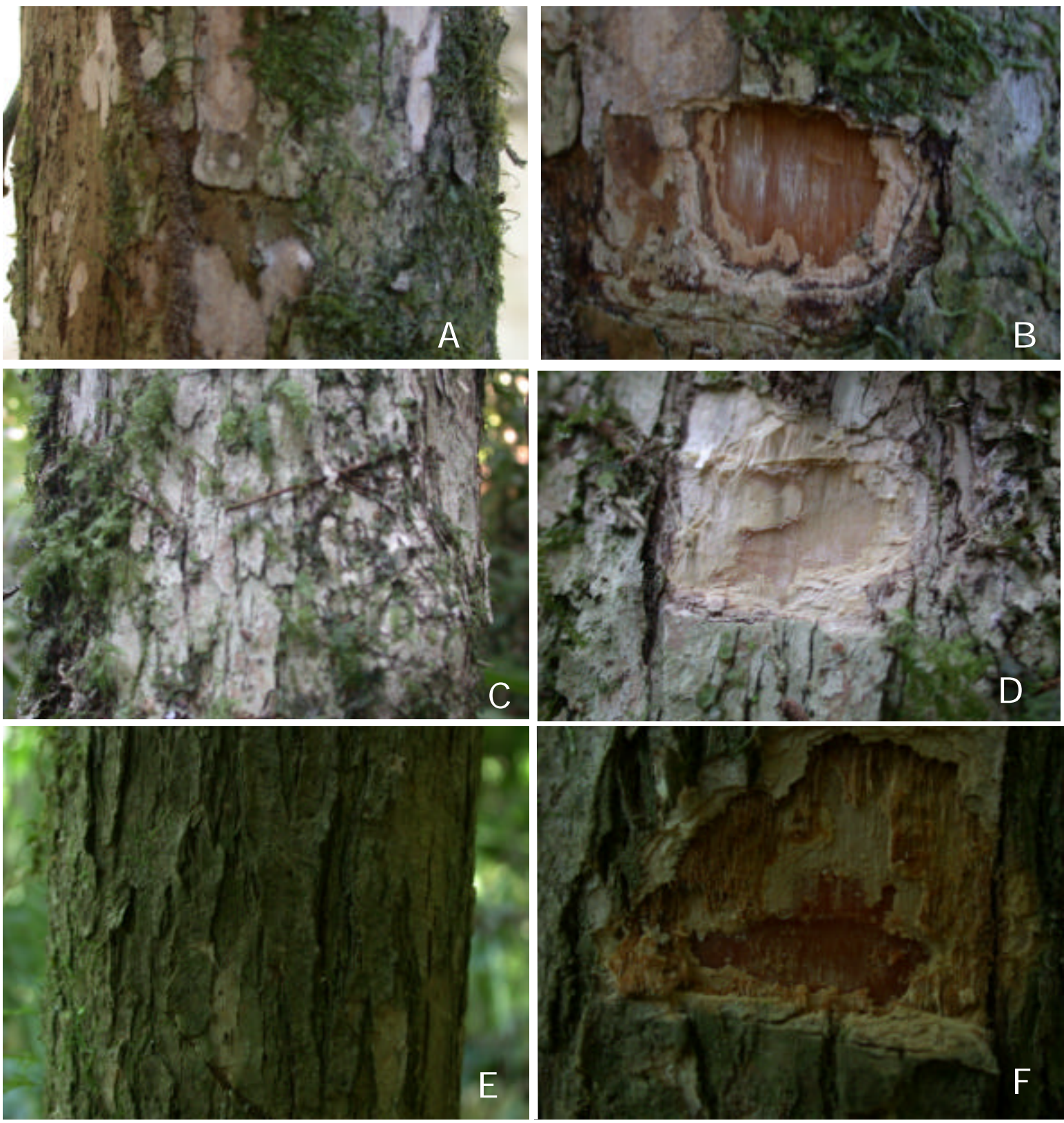

Figura 29 - Troncos de espécies de Myrtaceae ocorrentes no Parque Estadual Carlos Botelho: A. Campomanesia sp. - aspecto externo; B. Campomanesia sp. aspecto interno; C. Eugenia cereja - aspecto externo; D. E. cereja - aspecto interno; E. E. oblongata - aspecto externo; F. E. oblongata - aspecto interno 

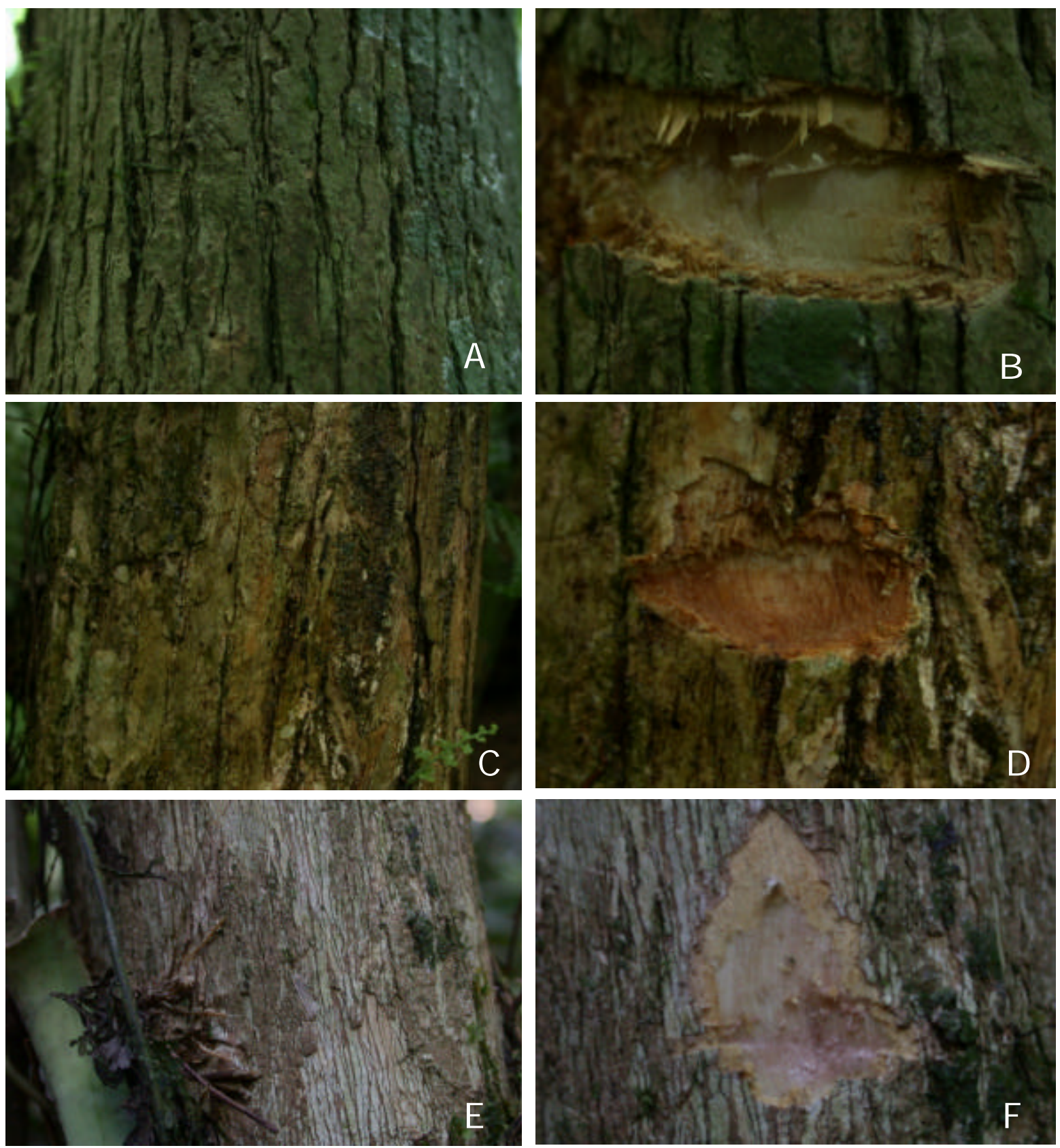

Figura 30 - Troncos de espécies de Myrtaceae ocorrentes no Parque Estadual Carlos Botelho: A. Eugenia bocainensis - aspecto externo; B. E. bocainensis - aspecto interno; C. E. cambucarana - aspecto externo; D. E. cambucarana - aspecto interno; E. E. cuprea - aspecto externo; F. E. cuprea - aspecto interno 

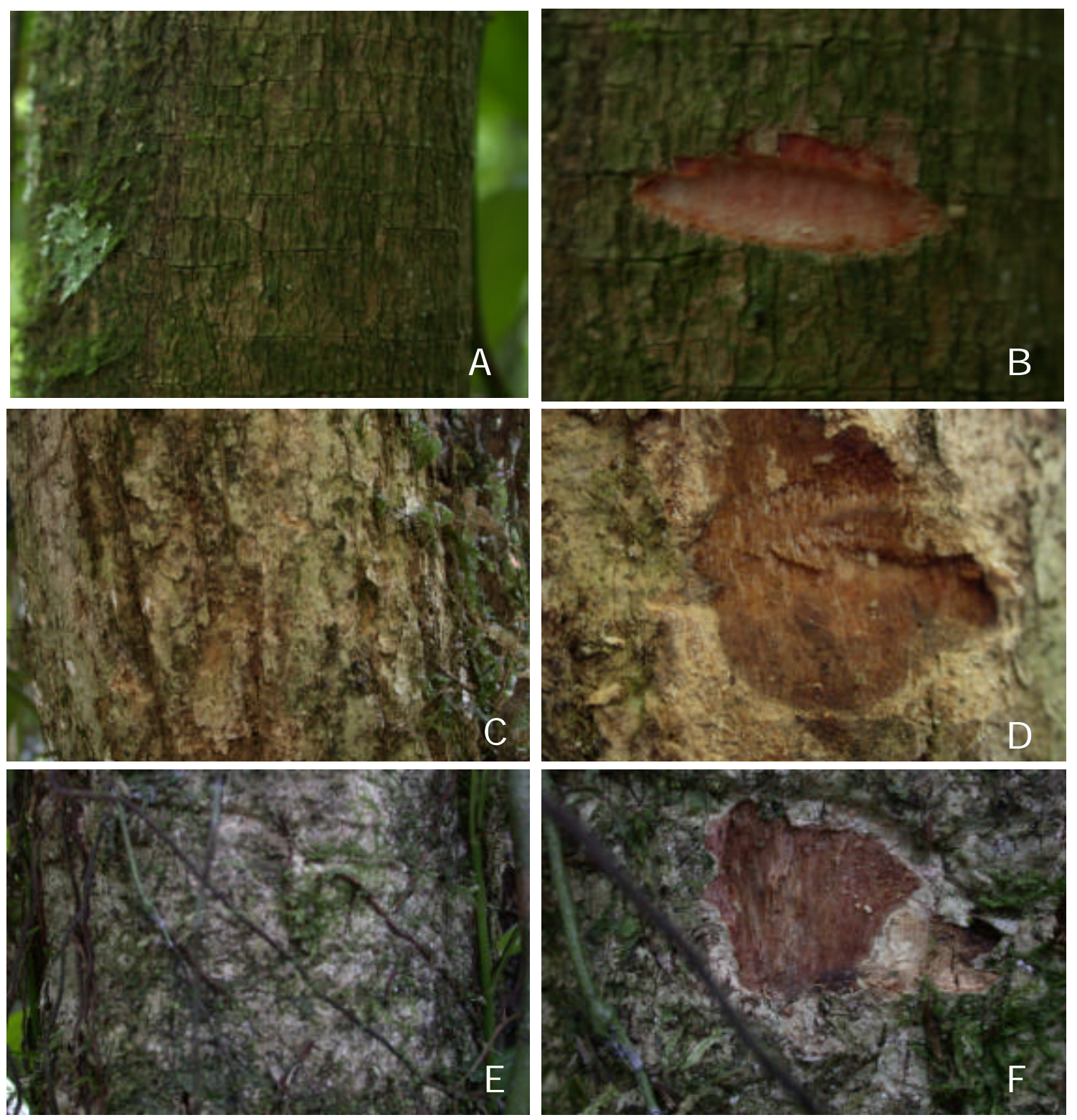

Figura 31 - Troncos de espécies de Myrtaceae ocorrentes no Parque Estadual Carlos Botelho: A. Eugenia pruinosa - aspecto externo; B. E. pruinosa - aspecto interno; C. E. melanogyna - aspecto externo; D. E. melanogyna - aspecto interno; E. E. mosenii - aspecto externo; F. E. mosenii - aspecto interno 


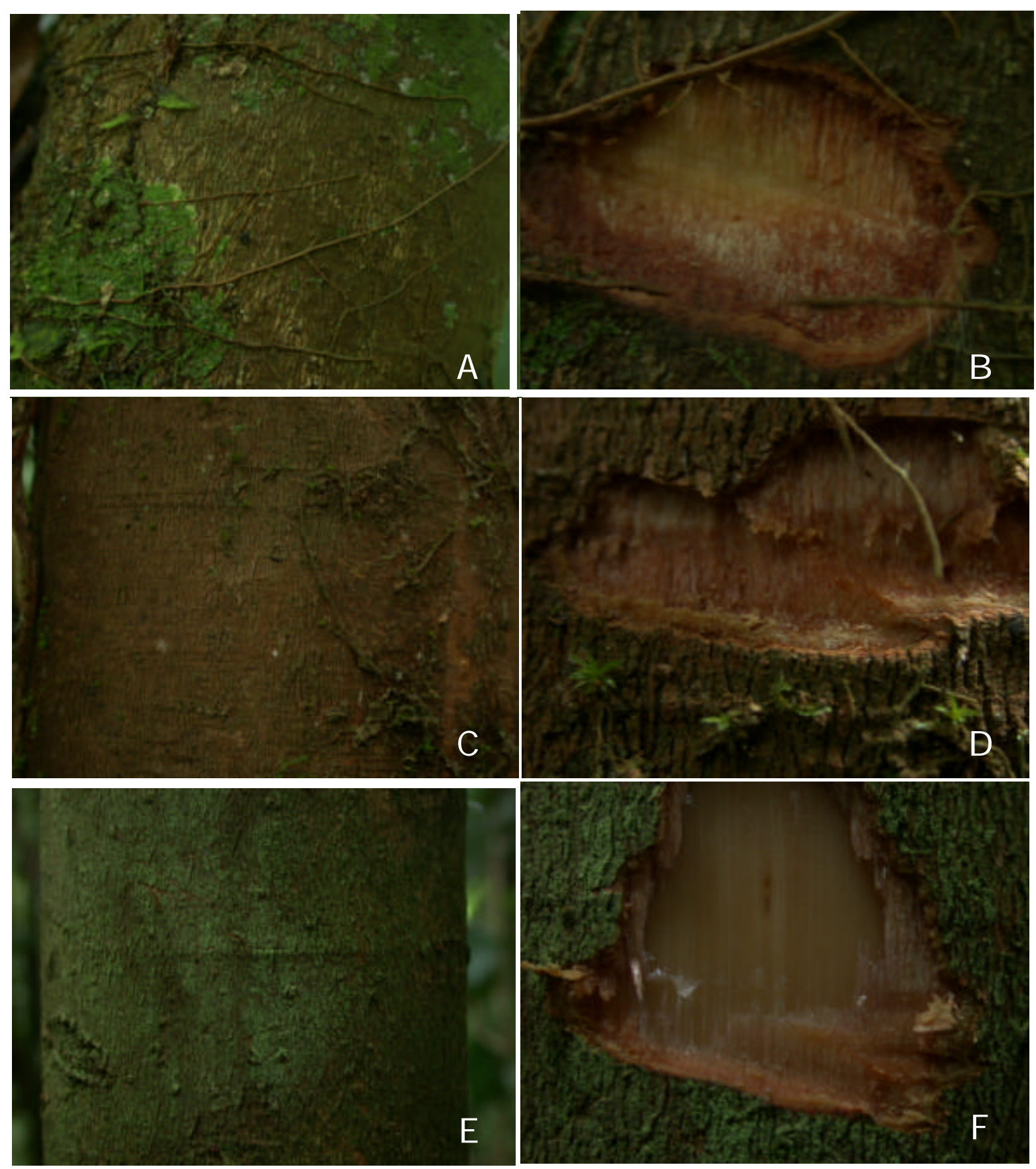

Figura 32 - Troncos de espécies de Myrtaceae ocorrentes no Parque Estadual Carlos Botelho: A. Gomidesia anacardiaefolia - aspecto externo; B. G. anacardiaefolia - aspecto interno; C. Gomidesia spectabilis - aspecto externo; D. G. spectabilis - aspecto interno; E. G. tijucensis - aspecto externo; F. G. tijucensis - aspecto interno 


\subsection{ASPECTOS RELACIONADOS A DENSIDADE ABSOLUTA E FREQÜÊNCIA} $\underline{\text { ABSOLUTA }}$

Numa breve análise dos dados de freqüência e densidade absolutas das espécies encontradas na área de estudo (Tabela 1), observoutse que Marlierea suaveolens é a espécie com maior frequiência absoluta ocorrendo em 40,6\% das parcelas amostradas, seguida por Gomidesia flagellaris e Eugenia cuprea com 37,5\%. Todas estas possuem densidades absolutas bastante próximas, sendo E. cuprea a que apresenta maior, o que condiz com observações de campo que apontam para a ocorrência agregada desta espécie. Vale destacar que as três espécies citadas acima ocorrem no subosque da floresta, o que corrobora com dados de Ivanauskas et al. (2001), segundo os quais as espécies deste estrato geralmente apresentam densidades absolutas maiores. Comparando-se os dados de densidade e frequiência absolutas obtidos para Marlierea tomentosa, Eugenia melanogyna, e Eugenia mosenii (12,2 e 32,8\%; 10,4 e 27,0\%, e 11,1 e 23,8\%, respectivamente) nota-se o mesmo fato observado anteriormente, isto é, embora as espécies tenham densidades bastante próximas, as frequiências em E. mosenii e Eugenia melanogyna são consideravelmente menores, refletindo uma maior agregação destas em relação à primeira. De qualquer forma, a análise e interpretação destes dados são apenas preliminares e necessitam de um maior refinamento, inclusive contrapondoos com dados de outros trabalhos semelhantes. 


\section{CONCLUSÕES}

Das 48 espécies de Myrtaceae assinaladas por Custódio Filho (2002) para o Parque Estadual Carlos Botelho, sendo 30 delas identificadas até ao nível de espécie, apenas 23 foram amostradas na área do presente trabalho, o que se justifica pelo fato daquele trabalho possuir uma maior área de abrangência, isto é, nele foram realizadas coletas em toda a área do Parque. De qualquer forma, no presente trabalho, registram-se 24 novas ocorrências de Myrtaceae para o Parque Estadual Carlos Botelho. Somando-se apenas as espécies identificadas até nível específico chegaremos então ao número de 54 espécies para toda a área do Parque. A título de comparação, Ivanauskas et al. (2001), trabalhando na área de Floresta Atlântica de Pariquera-Açu-SP, encontrou 48 espécies de Myrtaceae, sendo 32 identificadas até o nível de espécie, das quais, 16 coincidem com espécies presentes na área da Parcela Permanente.

Através deste trabalho foi possível confirmar as afirmações de outros autores, como Ivanauskas et al. (2001), Landrum \& Kawasaki (1997), Barroso (1995), e Custódio-Filho et al. (1992) referentes à complexidade taxonômica das Myrtaceae. De fato, apenas através da coleta de materiais em estado fértil foi possível uma identificação segura, sendo que em alguns casos, nos quais as espécies não foram coletadas em estado reprodutivo, a identificação permaneceu duvidosa, mesmo com uso de todos os recursos disponíveis. 
Apesar disto, uma vez reconhecida a identidade das espécies que ocorrem na área, a sua distinção é possível mesmo apenas através de caracteres vegetativos e, neste sentido, caracteres do tronco, ramos e folhas, desde que associados, podem permitir uma identificação mais precisa. 


\section{REFERÊNCIAS BIBLIOGRÁFICAS}

BARROSO, G.M.; PEIXOTO, A.L.; COSTA, C.G.; ICHASO, C.L; LIMA, H.C. Sistemática das angiospermas do Brasil. Minas Gerais: Ed. Univ. Fed. Viçosa, 1984. 377p.

BARROSO, G.M. Myrtaceae da Reserva Florestal de Linhares, Espírito Santo, Brasil -

Gêneros Calyptranthes e Marlierea. Boletim Museu Biológico Mello Leitão, v.3, p.3-38, 1995.

CAMARGO, M.N.; KLAMT, E.; KAUFTMAN, J.H. Classificação de solos usada em levantamentos pedológicos no Brasil. Boletim Informativo da Sociedade Brasileira de Ciência do Solo, v.12, p.11-33, 1987.

CAMPOS, G. Mappa florestal. Rio de Janeiro: Ed. Typ. Diretoria do Serviço de Estatística, 1912. 102p.

CRUZ, O. A serra do Mar e o litoral na área de Caraguatatuba. São Paulo: USP, Instituto de Geografia, 1974. 181p.

CUSTÓDIO-FILHO, A. A floresta ombrófila densa em diferentes altitudes no Parque Estadual Carlos Botelho. São Paulo, 2002. 169p. Tese (Doutorado) - Instituto de Biociências, Universidade de São Paulo.

CUSTÓDIO FILHO, A.; FRANCO, G.A.D.C.; DIAS, A.C.; NEGREIROS, O.C. Composição florística do estrato arbóreo do Parque Estadual de Carlos Botelho,SP. Revista do Instituto Florestal, v.4, p.184-191, 1992. 
DASMAN, R.F.; MILTON, J.P.; FREEMAN, P.H. Ecological principles for economic development. New York: John Wiley, 1973. 252 p.

DIAS, A.C. Estrutura e diversidade do componente arbóreo e a regeneração natural do palmito (Euterpe edulis) em um trecho de mata secundária, no Parque Estadual de Carlos Botelho, SP. Piracicaba, 1993. 130p. Dissertação (Mestrado) - Escola Superior de Agricultura "Luiz de Queiroz", Universidade de São Paulo.

DOMINGUES, E.N.; SÉRIO, F.C. Geomorfologia ambiental das escarpas do Núcleo de Caraguatatuba - SP. Revista do Instituto. Florestal, v.1,n.1, p.1-37, 1989.

DOMINGUES, E. N.; SILVA, D. A. Geomorfologia do Parque Estadual de Carlos Botelho (SP). Boletim Técnico do Instituto Florestal, v.42, p.71-105, 1988.

FIDALGO, O.; BONONI, V. L. R Técnicas de coleta, preservação e herborização de material botânico. São Paulo: Instituto de Botânica, 1984. 40p.

GASCON, C.; WILLIAMSON, G.B.; FONSECA, G.A.B. Receding forest edges and vanishing reserves. Science, v.288, p.1356-1358, 2000.

INSTITUTO DE PESQUISAS TECNOLÓGICAS DO ESTADO DE SÃO PAULO Mapa Geológico do Estado de São Paulo, Escala 1:500.000. São Paulo, 1981. v.2.

IVANAUSKAS, N.M.; MONTEIRO, R.; RODRIGUES, R.R. Similaridade florística entre áreas de floresta Atlântica no estado de São Paulo. Brazilian Journal of Ecology, v.1/2, p.71-81, 2000.

IVANAUSKAS, N.M. Levantamento Florístico de Trecho de Floresta Atlântica em Pariquera-Açu, - São Paulo. Naturalia, v.26, p.97-129, 2001.

KAWASAKI, M.L.; HOLST, B.K. Two new species of Plinia (Myrtaceae) from coastal forests of Brazil. Brittonia, v.54,n.2, p.94-98, 2002. 
LANDRUM, L.R.; KAWASAKI, M.L. The genera of Myrtaceae in Brazil: an illustrated synoptic treatment and identification keys. Brittonia, v.49,n.4, p.508-536, 1997.

LEITÃO-FILHO, H.F. Aspectos taxonômicos das florestas do Estado de São Paulo. Silvicultura em São Paulo, v.16,n.1, p.197-204, 1982.

LEITÃO-FILHO, H.F. Diversity of arboreal species in Atlantic rain Forest. Anais da Academia Brasileira de Ciências, p.91-96, 1994.

MANTOVANI, W. A dinâmica das florestas de encosta Atlântica. In: SIMPÓSIO DE ECOSSISTEMAS DA COSTA SUL E SUDESTE BRASILEIRA, 2., São Paulo, 1990. Anais São Paulo: 1990. p.304-313.

MANTOVANI, W. Dinâmica da Floresta Pluvial Atlântica. In: SIMPÓSIO DE ECOSSISTEMAS BRASILEIROS, 4., Águas de Lindóia, 1998. Anais Águas de Lindóia: 1998. p.1-20.

MORAES, P.R.L. de. Espécies utilizadas alimentação do mono cavoeiro (Brachyteles arachnoides E. Geofrey, 1806) no Parque Estadual de Carlos Botelho. Revista do Instituto Florestal, v.4, p.1208-1206, 1992.

MORAES, P.R.L. de. Caracterização morfológica de frutos, sementes e plântulas de espécies da família Lauraceae, no Parque Estadual de Carlos Botelho, São Paulo. Rio Claro, 1993. 234p. Dissertação (Mestrado) - Universidade Estadual Paulista "Júlio de Mesquita Filho".

MYERS, N. MITTERMEIER, R.A., MITTERMEIER, C.G., FONSECA, G.A.B.; KENT, J. Biodiversity hotspots for conservation priorites. Nature, v.403, p.853$858,2000$. 
NEGREIROS, O.C. Características fitossociológicas de uma floresta latifoliolada pluviosa tropical visando ao manejo do palmito, Euterpe edulis Mart. Piracicaba, 1982. p. Dissertação (Mestrado) - Escola Superior de Agricultura "Luiz de Queiroz", Universidade de São Paulo.

NEGREIROS, O.C.; CUSTÓDIO-FILHO, A.; DIAS, A.C.; FRANCO, G.A.D.C.; COUTO, H.T.Z; VIEIRA, M.G.L.; MOURA NETTO, B.V. Análise estrutural de um trecho de Floresta Pluvial Tropical, Parque Estadual Carlos Botelho, Núcleo Sete Barras (SP - Brasil). Revista do Instituto Florestal, v.7,n.1, p.1-33, 1995.

OLIVEIRA-FILHO, A.T.; FONTES, M.A.L. Patterns of floristic differentiation among Atlantic Forests in Southeastern Brazil, and influence of climate. Biotropica, v.32, p.793-810, 2000.

RANTA, P., BLOM, T., NIEMELÄ, J., JOENSUU, E.; SIITONEM, M. The fragmented Atlantic rain Forest of Brazil: size, shape and distribution of forest fragments. Biodiversity and Conservation, v.7, p.385-403,1998.

RIBEIRO, J.E.L. da S. Flora da Reserva Ducke: Guia de identificação das plantas vasculares de uma floresta de terra-firme na Amazônia Central. Manaus: INPA, 1999. 799p.

SCUDELLER, V.V., MARTINS, F.R.; SHEPHERD, G.J. Distribution and abundance of arboreal species in the atlantic ombrophilous dense forest in Southeastern Brazil. Plant Ecology v.152, p.185-199, 2001.

SETZER, J. Contribuição para o estudo do clima do Estado de São Paulo. Escolas Profissionais Salesianas. São Paulo, s ed.1946. 200p. 
SILVA, J.M.C.; TABARELLI, M. Tree species impoverishment and the future flora of the Atlantic forest of northeast Brazil. Nature v.404, p.72-74, 2000.

SOS MATA ATLÂNTICA. Atlas da evolução dos remanescentes florestais e ecossistemas associados no domínio da Mata Atlântica de 1990-1995. São Paulo: SOS Mata Atlântica, 1998. 1v.

VELOSO, H.P.; GÓES-FILHO, L. Fitogeografia brasileira: classificação fisionômicoecológica da vegetação Neotropical. Salvador, 1982. 86p.

WRIGHT, D.D., JESSEN, J.H., BURKE, B.; GARZA, H.G.S. Tree and liana enumeration diversity on a one-hectare plot in Papua New Guinea, Biotropica, v.29,n.3, p.250-260, 1997. 